\title{
TOWARDS A HUMAN RIGHTS - BASED CONTRACEPTIVE POLICY: A CRITIQUE OF ANTI-STERILISATION LAW IN POLAND
}

by

Małgorzata Ewa Rutkiewicz

A Thesis Submitted in Conformity with the Requirements for the Degree of Master of Laws Graduate Department of the Faculty of Law University of Toronto

() Copyright by Małgorzata Ewa Rutkiewicz, 2000 
National Library

of Canada

Acquisitions and Bibliographic Services

395 Wellington Street Ottawa ON K1A ON4 Canada
Bibliothèque nationale du Canada

Acquisitions et services bibliographiques

395, ne Wellington

Ottawa ON K1A ON4

Canada
The author has granted a nonexclusive licence allowing the National Library of Canada to reproduce, loan, distribute or sell copies of this thesis in microform, paper or electronic formats.

The author retains ownership of the copyright in this thesis. Neither the thesis nor substantial extracts from it may be printed or otherwise reproduced without the author's permission.
L'auteur a accordé une licence non exclusive permettant à la Bibliothèque nationale du Canada de reproduire, prêter, distribuer ou vendre des copies de cette thèse sous la forme de microfiche/film, de reproduction sur papier ou sur format électronique.

L'auteur conserve la propriété du droit d'auteur qui protège cette thèse. $\mathrm{Ni}$ la thèse ni des extraits substantiels de celle-ci ne doivent être imprimés ou autrement reproduits sans son autorisation. 


\title{
TOWARDS A HUMAN RIGHTS - BASED CONTRACEPTIVE POLICY: A CRITIQUE OF ANTI-STERILISATION LAW IN POLAND
}

\author{
Master of Laws, 2000
}

\section{Małgorzata Ewa Rutkiewicz}

\section{Graduate Department of the Faculty of Law, University of Toronto}

\begin{abstract}
Sterilisation is one of the safest. most effective and most widely used method of family planning in the world. However, it is illegal and inaccessible in Poland. This thesis argues that there are certain harms imposed by the anti-sterilisation policy in Poland, and that they amount to a violation of human rights. It argues that limiting access to a comprehensive range of contraceptive option is harmful for reproductive and sexual well-being. Certain concerns associated with contraceptive sterilisation (e.g. fear of abuse or post-sterilisation regret) would be addressed more appropriately by less restrictive measures that respect rights of individuals and better respond to their needs. I argue that an array of contraceptive options that is as comprehensive as medical technology and modern health policy will allow is a necessary component of equality for women. As such, sterilisation policy should be part of the comprehensive reproductive health policy, which should be built upon principles of equality and public health rather than on moralities, myths and popular misconceptions about the people's capacity to control fertility.
\end{abstract}




\section{ACKNOWLEDGMENTS}

I would first like to thank Professor Rebecca Cook for her enthusiastic and dedicated supervision of my work. Her support, insightful comments, ideas and encouragement have helped me to develop my work and to take full advantage of my graduate studies in Canada. She has also helped me to get a wonderful start in my work in the area of Reproductive Health Law by teaching, advising on research and introducing me to others working in this field. I would also like to thank Professor Bernard Dickens for his insightful comments, teaching and input as a second reader.

I would like to acknowledge the very generous support of the Graduate Scholarship in Reproductive Health Law. which made it possible for me to study at the University of Toronto.

In my work I have turned for assistance to several non-governmental organisations, which have readily shared their resources and expertise. I want to express my gratitude, in particular, to: Wanda Nowicka from Federacja na Rzecz Kobiet i Planowania Rodziny (Federation for Women and Family Planning), Mindy Roseman from the Center for Reproductive Law and Policy, and Rachel Pine from AVSC International.

I want to express my appreciation for and gratefulness to Graduate Programme Coordinator, Julia Hall, without whose help at many critical times was invaluable to me, as well as to all graduate students. I also want to thank Tracey Pegg, Administrative Coordinator of the International Programme on Reproductive and Sexual Health Law at the Faculty of Law.

Thanks also to my supportive and patient family, who I have dearly missed during my wonderful stay in Toronto; my parents, my Grandmother, my sister, her husband and, of course, my beloved nephew, Krzyś.

Finally, I want to thank Tom, who commented on my work, helped in many difficult moments and who was always very supportive. 


\section{TABLE OF CONTENTS}

CHAPTER I. INTRODUCTION

CHAPTER II. POLAND'S ANTI-STERILISATION LAW: SUBSTANCE, HARM AND RATIONALE

PART A. The Legal Status of Sterilisation in Poland

PART B. Analysing the Harms to Polish Society of Inaccessibility of Sterilisation (Nature of the Harm) 15

Factual Background

Analysis of Implications

Conclusion

PART C. Perceived Harms of Legalisation of Sterilisation

CHAPTER III. THE LACK OF ACCESS TO STERILISATION AS A VIOLATION OF HUMAN RIGHTS

PART A. Introduction

The Place of International Human Rights Law in the Polish Legal System 42

Provisions of the Polish Constitution Pertaining to the Human Rights Protection 44

Conclusion - Polish Law and International Law 45

$\begin{array}{ll}\text { PART B. The Right to "Health" } & 48\end{array}$

The Concept of Health 49

$\begin{array}{ll}\text { Enforceability } & 50\end{array}$

Polish Provisions on the Right to Health

Conclusion on the Right to Health

PART C. The Right to "Respect for Private and Family Life"

$\begin{array}{ll}\text { Introduction } & 56\end{array}$

$\begin{array}{ll}\text { The Harm } & 60\end{array}$

Response of International Law 61

Conclusion on the Right to Respect for Private and Family Life 73 
$\begin{array}{ll}\text { PART D. The Right to "Equality" } & 87\end{array}$

$\begin{array}{ll}\text { Introduction } & 87\end{array}$

Spelling Out the Problem $\quad 88$

The Response of International Law

$\begin{array}{ll}\text { Non-discrimination in the Polish Constitutional Law } & 103\end{array}$

$\begin{array}{ll}\text { Conclusion on Equality } & 107\end{array}$

$\begin{array}{ll}\text { PART E. Conclusion } & 110\end{array}$

CHAPTER IV. JUSTIFICATIONS OF ANTI-STERILISATION LAW IN POLAND 112

$\begin{array}{ll}\text { PART A. Introduction } & 112\end{array}$

$\begin{array}{ll}\text { PART B. Protection of the Economic Well-being } & 115\end{array}$

$\begin{array}{ll}\text { PART C. Protection of Morals } & 128\end{array}$

$\begin{array}{ll}\text { Introduction } & 128\end{array}$

"Immorality" of Sterilisation $\quad 130$

Collective versus Individual Morality $\quad 139$

$\begin{array}{ll}\text { Role of Women in Shaping "Collective Morality" } & 141\end{array}$

Scrutinising the Necessity of the Measure $\quad 142$

$\begin{array}{lr}\text { PART D. Protection of Health } & 148\end{array}$

$\begin{array}{ll}\text { Introduction } & 148\end{array}$

$\begin{array}{lr}\text { Sterilisation as a Health Harm } & 150\end{array}$

Protection from Negative Implications of the Irreversibility of Sterilisation: Post-sterilisation Regret 154

Protection from Abuse

PART E. Conclusion 


\section{CHAPTER I.}

\section{INTRODUCTION}

Sterilisation is one of the most widely used methods of protection against unwanted pregnancy in the world. It is a relatively safe, quick, convenient, inexpensive and effective method of contraception. Women and their partners in many countries of the world can take advantage of this method to put an end to child-bearing when they decide that this is the best solution for their life-plans, their well-being, the welfare of their family and existing children. However, in Poland, this method is practically not accessible as a method of family planning. This thesis explores the question whether contraceptive sterilisation should be legalised and made accessible for the Polish society.

The reasons for exploring this issue are several. First, we can look at the accessibility of sterilisation in the broader perspective of accessibility of comprehensive range of family planning methods in Poland. In doing so. we will note several alarming tendencies. In 1997. Polish Constitutional Tribunal rejected as unconstitutional a legal reform liberalising access to abortion and making it available on social grounds, sustaining in this way the restrictive abortion law introduced in 1993. Unless the pregnancy constitutes a threat to woman's life or health; or if it results from a criminal assault, or else, when a foetus is genetically or otherwise seriously impaired, abortion is outlawed. One would think that such radical change, as compared to forty years of very liberal abortion laws in Poland, would prompt the state to secure access to means preventing women from unwanted pregnancies and assist them in not being forced into situations where they would turn to illegal abortions. However, such response has not taken place. In fact, in 1998, the Polish government withdrew subsidies for five out of eight available oral contraceptives, limiting drastically their affordability. Moreover, no state programmes or policies exist which would promote and facilitate access to modern methods of family planning. What that implies for Polish families is that access to means of protection from unwanted pregnancies is rendered increasingly more difficult, not easier. 
The second reason for focusing on accessibility of sterilisation comes from taking a reproductive health perspective. What must be noticed is that in the last ten years a radical change has taken place in this sphere. This is most visible when we look at outcomes of the 1994 United Nations International Conference on Population and Development in Cairo and 1995 World Conference on Women in Beijing. The evolution reflected in the final documents of these conferences concerns the requirement that countries form and advance comprehensive strategies, reproductive health policies, which would follow principles, guidelines and standards developed in last years and which would have as their goal the well-being of members of the society. Poland has not met this requirement. The government's approach to matters associated with reproduction, reproductive health and reproductive services is neither uniform nor stable. It is not based on clearly explicated principles or guidelines, but rather it is seen as a very political and ideological topic.

Finally, from the comparative perspective. it seems that Polish anti-sterilisation law poses some apparent questions. First, sterilisation is the only contraceptive method criminalised in the Polish law. Second, as it was stated earlier. sterilisation is one of the most widely used methods on a global scale. Moreover, many post-communist countries, for example Russia and Hungary, which have been undergoing a similar transition in terms of economic and political situation as Poland has, introduced recently policies regulating access to sterilisation on liberal terms. Polish authorities, on the other hand, have left the issue of restrictive sterilisation law unattended. Likewise, this method is often available even in countries with restrictive policies towards abortion, such as Ireland. All of these reasons guide us to ask such questions as: what reasons lie behind the anti-sterilisation law, is the ban on sterilisation necessary, is the ban on sterilisation harmful, should the law change and why.

The task requires first to examine carefully the legal status of sterilisation, since there exists certain controversy whether the provisions of criminal code apply to this procedure. Such controversy is mostly attributable to the lack of enforcement of the law. It is also necessary to lay out all available information concerning the popularity of this method, society's awareness of it or the existing need for its accessibility, however scarce this data may be. The goal of such review is to give a factual background to further analysis of its implications. 
As the next step, two sides of anti sterilisation law should be explored - on the one hand, negative implications of the law, and, on the other, the implied advantages for individuals and society of having such restriction. In other words, we want to look at potential harms of the lack of access to this method, as well as, at the implied harms of its proposed legalisation. In order to analyse negative implications of anti-sterilisation law, first of all, one should look at reasons for the popularity of this method in other countries. Furthermore, the connection hetween the access to sterilisation, on the one hand, and sexual and reproductive health, on the other, shall be of importance. A different focus is required with regard to various groups of the society affected by this restriction: women, whose situation in connection with pregnancy, childbearing and childcare is distinct; men, for whom sterilisation is one of few available contraceptive options; and physicians. potential or actual providers of this service. I want to demonstrate that sterilisation as a contraceptive method has a lot of positive features and its accessibility can have positive influence on the lives of individuals and society.

As the next step I want to argue that the harms of anti-sterilisation law are such that they could amount to violations of provisions of international human rights law and equivalent provisions of the Polish Constitution. To this end, I undertake the task of analysing whether such provisions as: the right to health, the right to respect for private and family life and the right to equality give protection against the harms of anti-sterilisation law. The discussion here concentrates on relevant jurisprudence of international judicial and quasi-judicial bodies, and, where available and applicable, the jurisprudence of the Polish Constitutional Tribunal or Polish courts. The method utilised here is to project how the argument for legalising sterilisation could be made under the international human rights treaties, in particular: the European Convention on Human Rights, and the International Covenant on Civil and Political Rights. In doing so, obstacles that such argument would have to overcome should be discerned and evaluation of the feasibility and effectiveness of such argument should be made.

In arguing a violation of human rights provisions, discussion of harms of anti-sterilisation law is again only one side of the analysis. The other aspect of the question about sterilisation policy is to identify sources of resistance to legal and accessible sterilisation. The question is what concerns such a change is likely raise. Sterilisation is not without its shortcomings as a 
contraceptive method. There are several implications of its permanent character and irreversibility. There is an "ethical" concern associated with this method, the perception by some that the performance of contraceptive sterilisation is simply wrong. In Poland, these concerns can be attributed to:

- the influence of the Catholic church doctrine;

- the ascription of a speciai value to the ability to procreate in the Polisir society;

- the lack of open discussion on sexuality and sexual health; and

- a narrow understanding of well-being and health.

Another set of concerns is demographic: the linking of sterilisation with declining birth rates and an ageing population. Yet another barrier is an entrenched belief that sterilisation is inherently susceptible to abuse, a belief associated in large part with Nazi practices of coerced sterilisation and sterilisation experiments on women in concentration camps during World War II. The second phase of the analysis thus. is the juxtaposition of harms of the existing restriction with concerns about its dismantling. What will be done at this point is the weighing of arguments for and against the legal reform. In considering this question, I want to point out that the complete proscription of sterilisation is not the only available mean of addressing the implied harms and concerns expressed with regard to the wide accessibility of this method.

Sterilisation is not an ideal contraceptive and has some disadvantages which would necessarily have to be addressed if it was legalised in Poland. For example, because of its permanent character, special attention needs to be paid to ensure that the decision to apply this method is made voluntarily and with a full knowledge about its features, implications and alternatives. However, I want to demonstrate in this thesis that inaccessibility of sterilisation combined with the lack of access to abortion and difficult situation with regard to other methods of family planning outweighs state's interests in outlawing it. The concerns associated with contraceptive sterilisation can be addressed in ways other than by criminalising this procedure. 
CHAPTER II.

\section{POLAND'S ANTI-STERILISATION LAW:}

\section{SUBSTANCE, HARM AND RATIONALE}

\section{PART A. The Legal Status of Sterilisation in Poland}

There are no regulations in the Polish legal system that specifically concern sterilisation in any of its forms: voluntary. involuntary, therapeutic or non-therapeutic. However. Article 156 $\$ 1$ of the Polish Criminal Code $1997^{-1}$ (Criminal Code) criminalises the deprivation of the ability to procreate as an offence of the intentional infliction of a severe health detriment. along with the deprivation of the ability to see or the ability to hear and speak. Art. 156 is placed in Chapter XIX of the Criminal Code entitled "Offences against life and heaith." Article 156 reads:

Art. 156. $\$ 1$. Who inflicts a severe health detriment in the form of:

1) depriving a person of ability to see, hear, speak or procreate. [or]

2) causes other severe impairment .... terminal disease, ....

will be punished with imprisonment from one to 10 years. ${ }^{3}$

\footnotetext{
'Ustawa = dnia 6 czerwca 1997 r. Kodeks karny (Criminal Code from 6 June 1997) Dz.U. 1997 Nr 88 poz. 553 , Dz.U. $1997 \mathrm{Nr} 128$ poz. 840 [hereinafter: Criminal Code]. Polish Criminal Code is divided into three parts: General Part, Special Part and Military Part. The General Part treats of such matters as the basis of criminal liability. These principles apply to every offence, which is included in the Special Part. In this Part of the thesis I will mention principles, which are provided in Art. $2 \$ 1$ and Art. 26 of the CC. Art. $2 \$ 1$ reads: "A prohibited act, which is not socially pernicious or which is socially pernicious to a minimal degree, does not constitute an offence." Art. $26 \$ 1$ reads: "Whoever acts with the purpose of averting an immediate danger threatening a good protected by the law; if the danger may not otherwise be avoided and the good sacrificed represents lesser value than the good being rescued, shall not commit an offence."

"Chapter XIX is one of 22 chapters included in the Special Part of the Code. Each chapter of this Part creates a special category of offences. Chapters are organised in the order reflecting the seriousness of offences. The first chapter of this Part - Chapter XVI, for example, introduces crimes against peace, crimes against humanity and war crimes. Two following chapters embrace offences directed against state interests, such as, for instance, espionage. Chapter XIX is the first chapter criminalising "private" offences - the most dangerous of them - directed against life and health. Art. 156 is placed in this chapter. Other offences regulated in this chapter include: murder (Art. 148 CC) or manslaughter (e.g. Art. $155 \mathrm{CC}$ ), as well as less serious forms of causing health detriment (those that are not qualified as severe - Art.157 CC). Another chapter from Special Part which will be mentioned in this work is Chapter XXV entitled "Offences Against Sexual Freedom and Decency."

${ }^{3}$ Criminal Code, supra note 1 Art. 156 para. 1.
} 
But for the explicit reference to the deprivation of the ability to procreate, one could argue that sterilisation might not constitute a severe health detriment. However, the article, as formulated, could apply to any sterilisation procedure, with some narrow exceptions. ${ }^{4}$ Where it is necessary for the protection of health or life and the deprivation of the ability to procreate is a side-cffect, the procedure does not come under the scope of Art. $156 \S 1$, since it can he said that the deprivation of the ability to procreate has not been directly intended by the operating physician, even though this effect is usually foreseen. It has been also accepted in Polish legal doctrine that sterilisation performed on a woman is not illegal if a pregnancy would constitute threat to her health or life, since a doctor could invoke a defence that such an act belongs in the category of medical treatments. ${ }^{5}$

These two categories of sterilisation operations are described as medically necessary or. in other words, as therapeutic sterilisation. One important aspect of therapeutic procedures, which is one of the conditions (besides the observance of the medical standards of proceedings) of their immunity, is that they are performed with the consent of a patient. ${ }^{\circ}$ Sterilisation operations of women who have undergone several caesarean section, and for whom the next pregnancy could be dangerous belong to this category of therapeutic sterilisations and are the most common in Polish medical practice.' Such sterilisations are sometimes performed immediately following the last caesarean section, because of a technical facilitation.

Thus, there is no disagreement among Polish legal authorities that any form of involuntary, forced sterilisation, falls squarely under the scope of the Criminal Code and

\footnotetext{
"See e.g. E. Zielinska, "Warunki dopuszczalnosci zabiegow sterylizacji” (Conditions of Admissibility of Sterilisation) (1985) 9/1985 Panstwo i Prawo 66 at 67 (PiP 1985 nr 9) [hereinafter: "Conditions of Admissibility"]. s'bid.

- The exception from this rule is emergency procedures on a unconscious patients. Also, in case of a person not capable of giving a competent consent (minor, mentally disabled), the law might require that the consent be given by a legal guardian or, in some cases, be approved by a court.

${ }^{7}$ M. Sygut-Nowak, "Bezplodnosc na zyczenie: Czy sterylizacja powinna byc w Polsce legalna metoda antykoncepcyjna?" (Infertility on Request: Should Sterilisation Be a Legal Family Planning Method in Poland?) Wprost (10 August 1997) 58 at 58 [hereinafter: Wprost].
} 
constitutes the criminal offence of inflicting severe health detriment. ${ }^{8}$ This is distinct from nontherapeutic voluntary sterilisations, operations which are not medically necessary but are performed on the request from a patient, with his or her fully informed and competent consent, ${ }^{9}$ for the purpose of family planning. These have been sometimes referred to as sterilisations "for convenience", ${ }^{10}$ although the request for sterilisation can be made for a variety of reasons, such as a difficult material or life situation or a satisfaction with the present size of the family. Furthermore, the sterilisation of a man, whose partner's health is threatened by a pregnancy, needs to be included in this category, as the operation is not medically necessary for the protection of health of the person undergoing it."

The legal status of this category of sterilisation operation. the consensual non-therapeutic sterilisation. has raised some controversies in the Polish legal doctrine. In the majority opinion. non-therapeutic sterilisation falls within the scope of Art. $156 \$ 1$ of Criminal Code and constitutes the offence of inflicting severe health detriment. ${ }^{12}$ The restrictive effect of this provision has been considered by many scholars, already in the early sixties, as unnecessary and unjustified..$^{13}$ For this reason, they have attempted to explore whether it would be possible, on the basis of the interpretation of existing legal provisions, taking into consideration general principles of criminal law, to argue that Art. 156 would not apply to sterilisation. when performed with the consent of its recipient. The principles invoked by scholars include: the

' J. Sawicki, "Z problematyki lekarskiej w polskim prawie karnym" (Medical Issues in the Polish Criminal Law) in G. Williams, Swietosc zycia a prawo karne (Sanctity of Life and Criminal Law, edition in Polish) (Warszawa: Panstwowy Zaklad Wydawnictw Lekarskich, 1960) 336 at 342-343 [hereinafter: "Medical Issues in Criminal Law"].

${ }^{9}$ In this part I am only concerned with the legal status of sterilisation, which has been performed observing the requirements of informed and competent consent. The question of the necessity for precautions against involuntary sterilisation will be discussed in Chapter IV, Part D, below.

${ }^{10} \mathrm{~A}$. Wasek, "Czy dobrowolna sterylizacja jest przestepstwem?" ("Is Voluntary Sterilisation a Crime?”) (1988) 8/1988 Panstwo i Prawo 87 at 89 (P i P 8/1988).

"Conditions of Admissibility", supra note 4 at 67-68.

${ }^{12}$ See e.g. ibid at 68-69. See also "Medical Issues in Criminal Law", supra note 8 at 343-345. See also J. Radzicki, Ryzyko zabiegow lekarskich w prawie karnym (Warszawa, 1967) at 195.

${ }^{13}$ See e.g. "Medical Issues in Criminal Law", ibid at 344. See also "Conditions of Admissibility", ibid at 70. See also Wasek, supra note 10 at 94. 
situation of a high necessity, ${ }^{1+}$ the lack of the requisite element of social perniciousness ${ }^{15}$ and the defence of consent of the "victim."

The first principle - "the situation of a high necessity" is set out in Art. 26 of the Criminal Code. $^{16}$ It could potentially apply in the case where a man undergoes sterilisation in order to protect the health of his partner, where it would be threatened by pregnancy. The argument would be that the lesser good is sacrificed - the man's ability to procreate - for the sake of saving the greater good - the health or life of a woman. However, in Polish legal doctrine. the application of this institution is contingent upon three conditions: (1) the threat to the good which is being protected has to be immediate and direct; (2) the threat cannot be avoided in any other way; and (3) the value of goods sacrificed and protected is in due proportion. ${ }^{17}$ It has been suggested that in the case of sterilisation two of the above conditions would not be satisfied. ${ }^{18}$ First. there is no immediate threat to the health of a woman, the threat is remote, and it is conditioned on the fact that she becomes pregnant. Second. the danger could be avoided in other ways besides male sterilisation: sexual abstinence, other contraceptive means or. for example. abortion. ${ }^{19}$ On this view, the principle may not protect a physician from criminal liability.

The second principle has its source in Art. $1 \S 2$ of Criminal Code, which provides that an act does not constitute an offence if its social perniciousness is insignificant or none. ${ }^{20}$ This principle is based on the two-element definition of a criminal offence in Polish criminal law. The two components are the formal and material elements of the offence. The formal element is satisfied where a person's act falls under the description of the offence. The material element

\footnotetext{
it Polish name of the institution: stan wyzszej koniecznosci.

15 Polish name of the institution: brak spolecznego niebezpieczenstwa czynu.

${ }^{16}$ See supra note 1.

${ }^{17}$ Ibid

18 "Conditions of Admissibility", supra note 4 at 68.

19 Ibid.
}

20 See supra note 1. Under the previous Criminal Code 1969, Dz.U. $1969 \mathrm{Nr} 13$ poz. 94 (with amendments), the institution's name was "social dangerousness". For a brief description of the institution in English-language literature, see e.g. J. Stepan \& E.H. Kellogg, "The World's Laws Concerning Voluntary Sterilization for the Purposes of Family Planning" (1974) 5 Cal. W. Int'I L. J. 72 at 94-95. The change of the name in Criminal Code 1997 was made in response to critical opinions that the principle was being abused for political reasons under the communist regime. However, as a legal principle, the rationale for such principle has remained the same regardless of the name. 
requires the social perniciousness of the act to be significant. The purpose of this principle is to enable the courts and prosecutors to refrain from punishing petty misconduct or acts that would be otherwise socially acceptable. ${ }^{21}$ It allows the court to refrain from holding a person liable of an offence based on the factual circumstances of the case. The materiality principle, however, does little to assist the decriminalisation of voluntary sterilisation. First, because it is applied on a case-by-case basis, courts have a wide discretion to find sterilisation socially pernicious in any given case. Further, to pronounce generally that all voluntary, consensual sterilisation operations do not constitute criminal offences just because they do not satisfy the material element of crime in Polish law would likely conflict with Polish legal doctrine as an intrusion of courts or prosecutors into the competence of the legislature."

The last principle of criminal law with regard to voluntary sterilisation. is the defence of consent. This defence is not codified, but has been developed in criminal law doctrine. There are. again. certain conditions and limitations for the application of this defence. One of them holds that not all categories of values or goods protected by criminal law can be left to a person's discretion, and to the infringement of which. a person can effectively consent. The law takes some values into its protection, and this protectionism prevails over the consent of a person to the attack on certain values. ${ }^{23}$ One of the values that has been considered as falling into this particularly protected category is the right to be protected from the severe health detriment. ${ }^{24}$ There are, however. certain exceptions to this general rule. In the context of sterilisation, the most commonly invoked are: the consent to donation of an organ for the purpose of transplantation, and the surgery of sexual organs requested by a transsexual..$^{25}$ The first exception - organ donation - will only succeed if transplantation is the only method of saving the recipient's life or health. ${ }^{26}$ This condition, as discussed earlier with regard to the principle of

\footnotetext{
"S See e.g. L. Gardocki, Prawo karne (Criminal law) $4^{\text {th }}$ ed. (Warszawa: Wydawnictwo C.H. Beck, 1999) at 55 [hereinafter: Criminal Law].

$=$ See e.g. ibid. at 141.

${ }^{3}$ See e.g. ibid. at 123.

is See e.g. ibid.

${ }^{2 s}$ See e.g. ibid. See also Wasek, supra note 10 at 93.

26 "Conditions of Admissibility", supra note 4 at 69.
} 
higher necessity, would not be satisfied in the case of sterilisation. For this reason, it would not be possible, in the case of sterilisation, to argue that it is an analogous situation.

It may be more likely to succeed to attempt to draw analogy to the second exception - the case of transsexuals. However, there are certain factors that might render this analogy more difficult. In the case of sex-change operation there exists some strong evidence based on scientific rescarch, which links the issue of transsexualism with not only psychological disorder, but also suggesting, for example. that it has physiological basis in the structure of brain. and thus. bringing the issue of transsexualism into the sphere of health in the narrow, physical meaning. ${ }^{27}$ Sterilisation, on the other hand. is still mainly considered in terms of the improvement of social well-being and more speculatively - psychological well-being. I want to argue in the further chapters of this work that sterilisation operation should be also considered as benefiting the overall health of a person. Nevertheless, there might be a distinction drawn between medical benefits of the operation changing sex of a person and the sterilisation procedure. The benefits of the latter might be said to be more speculative, having weaker support in the scientific or medical evidence. Such distinction could defy the drawing of the analogy between the case of the operation of sex-change and the sterilisation procedure for the purposes of defence of consent in criminal law. It has to be pointed out that no authoritative body, so far, has attempted to draw such analogy between sterilisation and sex-change operation. For these reasons, this line of thinking does not influence the interpretation of the criminal law provisions applicable to sterilisation.

Further, attempt to rely on any of these three principles to exempt criminal sanctions in the case of voluntary sterilisation has one common fundamental flaw. While it would be possible in a particular case to use one or all of these principles to argue that a doctor should not face criminal sanctions, the effectiveness of these defences cannot be ascertained, as the court's decision is discretionary. Furthermore, none of this method result in the assertion that the

\footnotetext{
I7 See e.g. L.J.G. Gooren, "Biological Aspects of Transsexualism", Council of Europe Document no. CJ-DE/XXIII (93) 5. See also Zhou et al., "A Sex Difference in the Human Brain and its Relation to Transsexuality" (1995) 378 Nature 68.
} 
consensual sterilisation operations for contraceptive purposes as a category of acts does not fall within the scope of application of Art. $156 \S 1$ of the Criminal Code.

Scholar Andrzej Wasek asserted that consensual sterilisation should not fall within the scope of criminal law. He supported this view with a teleological interpretation of the provision concerning severe bodily harm, looking at the logic and purpose underlying the provision. ${ }^{28}$ His argument was made when the previous Criminal Code 1969 was still in force. He pointed to the contradiction existing in the legal system between a very liberal abortion law. allowing a woman to undergo abortion on her request, and the restriction of sterilisation, which involves less health risks and does not involve terminating foetal development. ${ }^{29}$ This argument. however. cannot be supported after the restriction of abortion law was introduced in $1993 .{ }^{30}$ None of the other arguments made by Wasek, (i.e. that the law is paternalistic if it prohibits consensual sterilisation or that it violates a person's right to self-determination) are useful to interpretation of the provision in force. but are more directed at appealing for a change of law.

One more issue that Wasek brings forward is the fact that the criminal provision has never, in practice, been applied by justice system in Poland in the case of sterilisation. ${ }^{31}$ No practitioner has ever been sentenced by a court for performing sterilisation, nor has there ever been charges brought against a physician by the prosecutor's office. And, as I will be discussing further. it is not because the procedure has only been performed for therapeutic reasons. Still, as long as the law is in force, it can potentially be enforced at any time. The doctrine of desuetude meaning a long-term non-application or non-observance of legal norms, which may result in the loss of its binding character - in Polish law may seem to assist in the decriminalisation of sterilisation. However, the concept has not been applied in judicial practice and thus, it meets with serious doubts as to who, when (after what period of non-application of the law) and in what

\footnotetext{
3 Wasek, supra note 10 at 87 . Wasek's argument has been made when the previous Criminal Code 1969, supra note 20, was still in force. There, the deprivation of the ability to procreate was described as a form of a severe bodily harm, not a severe health detriment.

9 Ibid. at 94.

${ }^{30}$ Ustawa zdnia 7 stycznia 1993 r. o planowaniu rodziny, ochronie plodu ludzkiego i warunkach dopuszczalnosci przerywania ciazy (Act on Family Planning, Human Embryo Protection and Conditions of Legal Pregnancy Termination from Jamuary 7, 1993) Dz. U. $1993 \mathrm{Nr} 17$ poz. 78, with amendments [hereinafter. Act on Family Planning].
} 
proceedings can pronounce its effects. ${ }^{32}$ Without some authoritative interpretation confirming the effect of desuetude, we should accept that the lack of enforcement is not by itself the evidence that the law could not be applied in the case of voluntary sterilisation.

Without a declaration from a court or tribunal that Art. $156 \S 1$ does not apply to nontherapeutic sterilisation, the only remaining is the restrictive interpretation. Thus, it can be cuncluded that in the current legal system, contraceptive stcrilisation is illegal and constitutes the criminal offence of inflicting severe health detriment. A physician charged with such an offence could submit several defences. but with no guarantee of success.

Such opinion about the legality of sterilisation is to be found in various informational materials available to general public and medical practitioners as well as in the statements of public officials. Information about methods of contraception is usually available in popular publications or guides and brochures published by family planning associations. Most of them will not mention sterilisation as a contraceptive method, and. if they do mention it. the information will be usually accompanied by a disclaimer that the method is illegal in Poland. ${ }^{33}$ In addition, the idea that sterilisation is illegal in Poland has often appeared in newspapers and other media. ${ }^{34}$ Finally, the illegality of sterilisation was publicly announced in 1997 by a high ranking official from the Ministry of Health. ${ }^{35}$

All these sources of information influence the general legal awareness with regard to sterilisation. In such circumstances, the general public and medical practitioners might either not be aware of sterilisation as a contraceptive option, or, if they are aware of it, they have reasons to

\footnotetext{
${ }^{31}$ Wasek, supra note 10 at 91.

${ }^{32}$ T. Stawecki \& P. Winczorek, Wstep do prawo:nawstwa (Introduction to Legal Theory), 2nd ed., (Warszawa: Wydawnictwo C.H. Beck, 1999) at 78.

${ }^{33}$ See e.g. A. Szarewski \& J. Guillebaud, Wszystko o antykoncepcji (Everything about Contraception) (Krakow: Medycyna Praktyczna, 1997) (popular publication on the methods of contraception). See also: online $<$ http:/www.linkownia.it.pl/antykoncepcja > (internet website on contraception targeted at young people). See also: Federacja na rzecz Kobiety i Planowania Rodziny (Federation for Women and Family Planning - FW\&FP), Sterylizacja: Trwala chirurgiczna metoda antykoncepcyjna (Sterilisation: Permanent Surgical Contraceptive Method) (leaflet published by the Federation).

${ }^{34}$ See e.g. "Legalizacja sterylizacji?" ("Legalisation of Sterilisation?") Gazeta Wyborcza (4 June 1997) 3. See also E. Olczyk "O zdrowiu reprodukcyjnym: Kobiety za legalizacja sterylizacji" ("Reproductive Health: Women in favour of Legalising Sterilisation”) Rzeczpospolita (27 February 1997) Section: kraj.
} 
doubt its legality. Doctors might fear the potential threat of criminal prosecution as well as the loss of their license, what can take place in disciplinary proceedings according to Art. 42.1 of the Act on Medical Associations. ${ }^{36}$ Thus, the medical profession is unwilling to perform the procedure. When asked by a patient about the possibility of being sterilised, the first answer from the physicians will most probably be that, they are not allowed to do it because it is illegal. This severely curtails accessibility of sterilisation.

This situation does not imply that non-therapeutic sterilisation is never performed for contraceptive purposes in Poland, although there is no exact data available on the number of illegal sterilisations performed. The only information available so far is anecdotal. gathered by non-governmental organisations involved in reproductive health matters, who have encountered men and women who obtained illegal sterilisation. Most such operations are performed on women, sometimes directly following delivery. ${ }^{37}$ One reason it is performed in connection with childbirth, besides the fact that it is technically facilitated, is that the chances of discovery are much smaller, whereas, if it was performed independently, the operation would have to be somehow recorded in medical files, most probably under the disguise of a therapeutic sterilisation, or some other procedure.

Not everybody, however will be able to access this service illegally, because finding a physician willing to perform it requires time and money. ${ }^{38}$ Not every doctor will take the risk of performing an illegal service, and if one does, he might charge an additional cost for taking the risk. An example is the case of a man, reported by the Federation for Women and Family Planning, who finally managed to find a doctor, who would perform vasectomy, after two years of searching for one. ${ }^{39}$

\footnotetext{
Is PAP (Polish Press Agency) press release, "Zdrowie - sterylizacja" ("Health: Sterilisation") (3 June 1997) [hereinafter: PAP press release]. See also: Wprost, supra note 7 at 58.

${ }^{36}$ Ustawa z dnia 17 maja 1989 r. o izbach lekarskich (Act on Medical Associations from May 17, 1989) Dz.U. 1989 $\mathrm{Nr} 30$, poz. 158, with amendments.

${ }^{37}$ PAP press release, supra note 35 .

${ }^{38}$ Federacja na Rzecz Kobiet i Planowania Rodziny (FW\&FP), "Sterylizacja i jej regulacja prawna" ("Sterilisation and its Legal Regulation") (1995) l (13) Seksuologia 23 at 24 [hereinafter: "Sterilisation and its Legal Regulation"]. ${ }^{39}$ PAP press release, supra note 35.
} 
Besides the general limited accessibility of therapeutic sterilisation, another consequence of its illegality is that women constitute the prevailing majority of illegal sterilisation operations' acceptors. ${ }^{10}$ The following factors contribute to such situation: women have much more opportunities of contact with specialists, who deal with methods of contraception and could have some information about the procedure or could give advise about it, for example, women usually visit gy naecolugisis on regular basis. Furthcrmorc, as it has been mentioned earlier, sterilisation can be performed in connection with delivery. Finally, women, as it will be discussed further in this work, are more determined to find effective methods of contraception, as they carry most of the burden of unwanted pregnancies.

As well, the denial of access to sterilisation means that for certain marginal groups, e.g. people living in remote areas and those having lower income, it is virtually inaccessible. given that these groups have limited choices of health facilities and physicians and limited financial resources.

In conclusion, although there may be some doubt as to whether consensual contraceptive (non-therapeutic) sterilisation falls under Article $156 \$ 1$ of the Criminal Code. both the plain meaning of this provision and how sterilisation is characterised in media and official government statements reaffirm a restrictive interpretation of this provision. This has a deterrent effect on medical profession. As a result, sterilisation is very difficult, and sometimes impossible, to access. Although the total number of illegal sterilisations is not known. it cannot be very high. ${ }^{41}$ Nevertheless, the evidence shows that it is sometimes performed illegally, much more often on women than men. Despite this, no one has yet been charged with performing it.

\footnotetext{
40 "Sterilisation and its Legal Regulation", supra note $\mathbf{3 8}$ at 25.

"I Federacja na rzecz Kobiet i Planowania Rodziny (FW\&FP), Zdrowie Reprodukcyjne Kobiet w Polsce (Reproductive Health of Women in Poland) (Warszawa: Federacja na rzecz Kobiet i Planowania Rodziny, 1997) at 31. (available in English online: FW\&FP Website <http:/www.waw.pdi.net/-polfedwo> (date accessed: September 17, 2000), also available in Polish from the Federation) [hereinafter: Reproductive Health of Women in Poland]. In the survey conducted by the FW\&FP, $2,4 \%$ of respondents declared that either they $(1,7 \%)$ or their partners $(0,7 \%)$ have undergone sterilisation. However, there has been no distinction made in the survey question between the therapeutic and non-therapeutic sterilisation.
} 


\section{PART B. Analysing the Harms to Polish Society of Inaccessibility of Sterilisation (Nature of the Harm)}

As it was discussed in Part A of this chapter the criminalisation of sterilisation results in the procedure being inaccessible or, at least, very difficult to access in Poland for people who could otherwise choose this method as a way to protect themselves from unwanted pregnancies, but for whom this procedure is not necessary for therapeutic reasons. Since it is illegal, those searching a suitable method of family planning, will usually not learn from doctors or other sources that it could potentially be available to them. If they do learn about it from some source. they will be usually informed that it is illegal in Poland, and that a doctor performing the procedure might potentially face the risk of criminal sanctions for performing it. Although the real risk of prosecution at present is minimal, it is a sufficient deterrent for the medical profession. who could also face the risk of disciplinary proceedings and the loss of a license to practice medicine.

The fact that this method is practically not accessible for family planning purposes, has. or can potentially have, negative implications on the lives of Polish men and women. as well as, more generally, families and society as a whole. In this chapter I want to look carefully at and analyse the meaning of the criminalisation of this service for lives of Polish people. In doing so, we should distinguish between two potentially affected groups: individuals, who could benefit from contraceptive sterilisation ${ }^{\text {t2 }}$ and physicians performing or willing to perform this procedure. ${ }^{13}$

\section{Factual Background}

First of all, I would like to discuss advantages of sterilisation as a birth-control method. This will help me identify categories of potential harm caused by its inaccessibility. I should not,

\footnotetext{
${ }^{12}$ Another distinction which will be discussed in this Part, below, is that the inaccessibility of this method affects men and women differently.

${ }^{43}$ The majority of discussion in this part will focus on implications for sterilisation acceptors. Only in the last heading of the section "Analysis of implications" - entitled: "Harms for medical profession", below, the focus will be on implications for the medical profession.
} 
certainly, ignore the disadvantages of this method, which are linked to the concerns, associated with the proposal to decriminalise this procedure. Such concerns will be considered in detail in subsequent chapters of the thesis.

Sterilisation is one of the most effective methods of preventing unwanted pregnancy. ${ }^{\text {H }}$ It can be described as an easy-to-use method in the sense that it is a one-time and permanent procedure, requiring oniy few visits to a ductur and no routine follow-up care or regular visits in order to, for example, obtain prescriptions. ${ }^{45}$ For these reasons, it is a relatively inexpensive contraceptive method. It does not require further systematic. repetitive application, such as, oral contraceptives require. Moreover, it does not interfere with the act of sexual intercourse itself, in a way that methods. which are to be applied before or during the intercourse. could interfere. Because it is a one-time and a permanent procedure. its effectiveness does not depend on the diligence of the recipient, there is no so-called user failure.

Another positive feature of sterilisation is that it is very safe as compared to other contraceptive methods, it has less side-effects. ${ }^{16}$ For this reason, it can be recommended and be particularly attractive for those who might be prevented from using other contraceptive means due to their particular side-effects. For instance. oral contraceptives are not recommended for smokers and women over 35 years, and all other groups that can be at a higher risk of cardiovascular disease and hypertension. ${ }^{77}$ Furthermore, oral contraceptives are sometimes, though not always, associated with such side-effects as: weight gain, nausea, headaches, depression and reduced libido. ${ }^{48}$ These side-effects are often discounted as insignificant, as they

\footnotetext{
" AVSC International, Reproductive Health: Voluntary Sterilization: Commonly Asked Questions (New York: AVSC International, 1999) at 5 [hereinafter: AVSC brochure]. The rates of failure of sterilisation reported there: for male sterilisation - vasectomy between $0.2 \%$ to $0.4 \%$, and for female sterilisation - between $0.3 \%$ to $0.4 \%$. See also: "The Canadian Conference on Contraception: Female and Male Sterilisation" (1998) $58 \mathrm{~J}$. SOGC. This source gives a ten years cumulative probability of failure as $1.8 \%$.

${ }^{15}$ S. Keller, Female Sterilization Safe, Very Effective (1997) 18 (1) Network, online: Family Health International Webpage <http://www. fhi.org> (date accessed: September 17, 2000).

${ }^{+6}$ AVSC brochure, supra note 44 at 2.

${ }^{17}$ International Planned Parenthood Federation (IPPF), International Medical Advisory Panel (IMAP), Statement on Contraception for Women over 35, 1997, online: IPPF Webpage <http:/www.ippf.org/imap/contr35/index.htm>.

${ }^{48}$ B. J. Oddens "Women's Satisfaction With Birth Control: A Population Survey of Physical and Psychological Effects of Oral Contraceptives, Intrauterine Devices, Condoms, Natural Family Planning and Sterilization Among 1466 Women" (1999) 59 Contraception 277 at 277 [hereinafter: "Women's Satisfaction with Birth Control"].
} 
do not endanger physical health. However, if we look at this issue from the perspective of a woman who might be experiencing these effects every day for many months or years, their significance for her should not be evaluated by anybody other than the woman herself. Intrauterine devices (IUDs) - another common contraceptive method - may cause heavier, prolonged and painful menstruation and their application may also result in genital infections. ${ }^{.9}$ While menstruai pain and heavier bleeding has also been experienced by women who have undergone sterilisation operations, it occurs to a lesser extent than in the case of IUDs. ${ }^{50}$

For male partner. one of the most important advantages of sterilisation is that it is practically only one of the two methods men can use. If they were prevented from using condoms. due to, for example, latex-allergies, sterilisation would become their only option.

It has been found that as many as $92 \%$ of the users of this method were satisfied with it. which is a higher percentage than that in the case of other contraceptive methods. ${ }^{51}$ The positive evaluation of this method is linked to the fact that users find this method as positively influencing their sex life, allowing them for more spontaneity, giving them more control over their sexual life, and making their sexual life more pleasurable. ${ }^{52}$

On the other hand, this method should be viewed as a regular surgical intervention. although not of a major character. Nevertheless, all potential risks of a surgery should be mentioned here, such as infection, bleeding or anaesthesia-related complications. In case of the failure of female sterilisation, in almost half of the cases, women have experienced ectopic pregnancies. ${ }^{53}$ However, as indicated above, the failure rates of this method are very low.

Finally, as far as disadvantages are concerned, sterilisation should be treated as permanent. ${ }^{54}$ In addition to that, this method of contraception does not give any protection from

\footnotetext{
s9 Ibid.

${ }^{50}$ Ibid.

${ }^{51}$ lbid at 280 . Levels of satisfaction of other methods: OC $68.4 \%$, IUD $58.6 \%$, Natural Family Planning (NFP) 42.8 , and Condoms 29.8. On the other hand, levels of dissatisfaction were following: Condoms $42.0 \%$, NFP 32.9, OC 13.6 and Sterilization - only $4.4 \%$.

52 Ibid. at 281-283.

53 AVSC brochure, supra note 44 at 4.

${ }^{54}$ For a more detailed discussion on this issue, see Part C, Chapter IV, below.
} 
sexually transmitted disease (STDs). The same can be said, however, about the natural family planning methods.

While it may not be the "ideal contraceptive," sterilisation is still very popular. To put this issue in perspective, there is no and, most probably will never be. an "ideal contraceptive," which would satisfy the needs of everybody. It must be taken into account, among others, that these needs change and are contingent on age of a person. his or her health conditions and lifestyle. ${ }^{56}$ Certain proposals of features of the "ideal contraceptive" have been proposed in the family planning literature. For example, the Working Group on Family Planning Methods at the XXII Conference of the Council for International Organizations on Ethics and Human Values in Family Planning in 1988 proposed the following set of them: affordability and accessibility. safety (i.e. minimum side-effects), ease of use, reversibility and reliability. ${ }^{57}$ Sterilisation seems to meet a lot of these requirements such as: effectiveness, safety, comfort and affordability, even though it fails with respect to the full safety and reversibility. Thus, it may constitute an attractive, and in some cases the only, option to certain individuals or groups of the society, in certain stages of their lives.

Because of the described above advantages, sterilisation is one of the most popular methods of contraception in the world. Female sterilisation itself is being used by about $32 \%$ of all users of modern contraceptive methods on the global scale. Male sterilisation is less popular; its users constitute about $7 \%$ of all contraceptive users globally. ${ }^{58}$ Sterilisation is more popular in less developed countries - constituting $38 \%$ (female) and $7 \%$ (male) of contraceptive use. In developed regions, its use is significant and comparable to the levels of popularity of condoms

\$s "Reports of the Working Groups: Family Planning Methods" in Z. Bankowski, J. Barzelatto \& A.M. Capron, eds., Ethics and Human Values in Family Planning (Geneva: Council for International Organizations of Medical Sciences (ClOMS), 1989) 248 at 249 [hereinafter: Ethics and Human Values].

${ }^{56}$ See e.g. "Changes in Contraceptive Use Among Canadian Women" (1999) 8(3) Can. J. Human Sexuality 203 at 203 [hereinafter: "Changes in Contraceptive Use"].

57 Ibid.

${ }^{58}$ United Nations, Department of Economic and Social Affairs, Population Division, Levels and Trends of Contraceptive Use as Assessed in 1998: Key Findings, online: Population Information Network (POPIN) Webpage <http://www.undp.org/popin> (date accessed: September 17, 2000). Popularity of other contraceptives: IUD 22\%, Oral Contraceptives (OC) $14 \%$, Condom $7 \%$, Injectables $3 \%$ and Other $15 \%$. 
and oral contraceptives - 12\% (female) and $7 \%$ (male). ${ }^{59}$ There are some countries, in more developed regions, where the rates of sterilisation use are much higher than on average. For example in the United States, $24 \%$ of women and $14 \%$ of men use sterilisation as a contraceptive method. ${ }^{60}$ There are also some countries where sterilisation is very popular, and in addition to that, more popular among men than women. For instance: in Canada - $14 \%$ of men and $10 \%$ of women have chosen stcrilisation ${ }^{61}$; in New Zealand- $19 \%$ of men and $15 \%$ of women $^{62}$; and in United Kingdom - 18 and $14 \%$ respectively. ${ }^{63}$ In Canada. the growing proportion of male to female sterilisation has been observed recently. This trend has been evaluated positively, because vasectomy is a much more simple. less expensive and faster procedure, which takes about fifteen minutes and does not require general anaesthesia. ${ }^{64} \mathrm{On}$ the European continent, sterilisation is popular in: Belgium. Denmark. France. the Netherlands (in the Netherlands, sterilisation rates of men are twice as high as that of women) and Switzerland. ${ }^{65}$

The above figures demonstrate that the Polish society is denied a contraceptive method which is one of the most popular methods globally and which is very popular in. for instance. many other European countries. Furthermore, Polish society is denied of the method, which has been usually evaluated as highly satisfactory by its users. Sterilisation, as a highly effective method, which does not depend in this respect on the user-failure, might be the best solution for women or their partners in situations, where they are determined to do everything in their

\footnotetext{
${ }^{59} \mathrm{Ibid}$. More developed regions: OC 24\%, Condom 19\%, and Other 30\%. Less developed regions: IUD 26\%, OC $4 \%$, Condom $4 \%$, and Other $10 \%$. What is worth noting is that rates of male to female sterilisations are different as compared between less and more developed countries. In more developed countries male sterilisation is almost as popular or, in some countries, even more popular (as will be demonstrated below) than female procedures.

${ }^{\infty}$ United Nations, World Contraceptive Use 1998. (New York: United Nations, 1999), online: POPIN Webpage, ibid. [hereinafter: UN World Contraceptive Use]. Data from U.S. were solicited in 1990.

ol "Sterilization Among Canadian Women and Their Parmers: Practices and Opinions" (1999) 8(3) Can. J. Human Sexuality 195 at 195 [hereinafter: "Sterilization Among Canadians"]. (data from 1998).

62 UN World Contraceptive Use, supra note 60. Data (preliminary or provisional) for New Zealand comes from 1995.

${ }^{63}$ Ibid.

ot "Sterilization Among Canadians", supra note 61 at 198.

${ }^{65}$ Ibid. Data from some other European countries (reported here for these countries, where data was available from more recent years - after 1989): Belarus (1995) - 1\% (female - f), Czech Republic (1995) 3\% (f), Germany - $1 \%$ (f), Hungary (1992/1993) - 4 (f) and 0.1 (male), Latvia - 2\% for both, Norway (1988/99) - $10(\mathrm{f})$ and $4(\mathrm{~m})$, Romania (1993) - 1 (f), Slovakia (1991) - 4 (f).
} 
capacity to avoid going through pregnancy or child-bearing. Denial of this method for the Polish people is a denial of one of the most effective and safe contraceptive method.

It has been previously noted that contraceptives needs differ because of different life situations, life styles or health conditions. Sterilisation. due to its permanent character, has been found to be particularly attractive and chosen mostly by married couples. ${ }^{66}$ Also, it is preferred by iung-term couples, on average married for at least ten or fiften years. In the majority of cases, couples choosing this method have two or more children. ${ }^{67}$ In the experience of providers. many requests for this service are being made by those who have reached the size of family they intended to have and sometimes already have more children than they wanted. ${ }^{68}$

What this implies is that Polish couples, who have reached the size of family that agrees with their life-plans, and, more often than not. with their financial and social capacities. will be denied the method best guaranteeing them the ability to make a choice whether to reproduce again.

\section{Analysis of Implications}

The picture so far suggests that the anti-sterilisation law is a restriction on the freedom of choice that citizens of other countries are allowed to exercise. What needs further demonstration are direct and indirect implications of this restriction on the lives of Polish people and Polish society.

Repression of sexuality and its potential consequences on individual well-being and family life

The denial of any form of contraception limits the choices that are available to individuals. This can be most clearly experienced by those who already have limited options due to, for example, health conditions. Of course, the methods which are always available for couples are natural family planning methods (NFP) - periodic abstinence methods: calendar method,

\footnotetext{
${ }^{66}$ See e.g. "Changes in Contraceptive Use", supra note 56 at 205.

${ }^{67}$ See e.g. S.G. Philliber \& W. W. Philliber, "Social and Psychological Perspectives on Voluntary Sterilization: A Review" (1985) 16:1 Studies in Family Planning 1 at 3.
} 
rhythm method or withdrawal (coitus interruptus); which do not have physical side-effects or health risks associated directly with its use. However, what the natural family planning methods cannot guarantee is spontaneity, regularity of sexual intercourse, and freedom from fear of pregnancy. In a study conducted in Germany, $29 \%$ of respondents using methods of natural family planning have experienced unwanted pregnancy. ${ }^{69}$ The efficiency of NFP is usually estimated as between $80-90 \%,{ }^{70}$ but it is very dependent on a couple's precision and diligence. That implies that on average one in four couples aiming at avoiding child-bearing through NFP will be unsuccessful in their efforts. In addition to that, this method encourages a couple to have a sexual intercourse at a time, when the female partner might have less sexual desire. and might be less inclined to have intercourse." On the other hand, a lot of pregnancies among users of NFP are the result of non-abstention in fertile periods. because of one partner persuading the other to have an intercourse or because of the shared need by a couple for this form of intimacy.

Thus, natural family planning methods are fallible or require periodic abstinence, in which case the need for sexual intimacy between people will be suppressed. at least in certain periods. Because of high failure rates, the sexual enjoyment. intimacy for people using NFP. more often than not. is compromised by the uncertainty about a resulting pregnancy. These deficiencies could be successfully resolved with artificial means of contraception. such as sterilisation.

It has to be emphasised again that the practice shows that sterilisation is mostly used by married couples or people in otherwise permanent relationships, who have been living for many years together. One of the reasons is that, if their relationship was less permanent, unstable, they would, most probably, not decide for such a "radical" form of contraception. Thus, the harms that will be discussed below, the harms of the denial of safe and effective contraception, resulting in the suppression of sexual intimacy or an interference with it by the fear of pregnancy, should be viewed, in the first place, from the perspective of a committed spousal relationship.

\footnotetext{
os lbid.

69 "Women's Satisfaction with Birth Control", supra note 48 at 281 .

${ }^{70}$ E. Olczyk, "Wiekszosc wybiera metody niepewne" ("Most Choose Unreliable Methods") Rzeczpospolita (26 September 1998) Section: kraj.
} 
The premise of this section is not to glorify sexuality or promote it as a paramount value or a panacea. The goal of this section is not to advocate sexuality for its own sake, for the mere physical pleasure it can give. This could be misunderstood as saying that sex is good regardless of a partner or situation. Rather, my argument is that sexual intimacy is a natural part of life, an important aspect of spousal or permanent relationships and that a healthy, satisfying sexual life is very important for the wcll-being of the relationship. Interference with this aspect of the relationship might result in harm both to individuals and to the relationship.

Sexual intimacy is important for building emotional intimacy. It can be "an expression of the qualities of love. commitment, fidelity, and mutual concern for one another." ${ }^{\text {"72 }}$ It affirms admiration, care for, and love for the partner, without which. the partner might feel unappreciated. As English psychiatrist. Dr. Jack Dominian stated in 1984:

Sexual intercourse is first and foremost an encounter of persons. It is the fulfilment of sexual intimacy at the social. emotional. intellectual. physical and spiritual level. Personal love and sexual pleasure together form the essence of the sexual act, not the biological potential. This is how intercourse is experienced by the couple and the attempt to make the procreative element supreme is a violation of its true meaning. Implicitly, the Church has always acknowledged this. giving permission for the sterile and the old to marry, and gradually allowing that intercourse may take place during pregnancy.... Spiritually, the sexual act is the central pivot that sustains the bond of the couple.... In the act of intercourse, the two persons donate the totality of themselves to each other. ${ }^{\text {s }}$

Further, Mark MacGuigan wrote in 1994:

[T] he act of sexual intercourse ... confirms sexual identity, through its encounter of two persons with differentiated characteristic, physically and emotionally. [I]t brings ... the complete acceptance of the other's selfhood. ${ }^{71}$

Lack of sexual intimacy can undermine the self-confidence and well-being of a partner. A lot of studies have linked satisfaction with sexual life and sexual intimacy with marital

${ }^{1}$ R. Radford Ruether, "Sex and the Body in the Catholic Tradition" (1999/2000) 20:4 Conscience 2 at 7.

Ibid. at 9.

73 "Humanae Vitae' Revisited (3): Beyond Biology" The Tablet (10 November 1984) I1 18; reprinted in M. R. MacGuigan, Abortion, Conscience and Democracy (Toronto: Hounslow Press, 1994) at 32-33. [emphasis added by MacGuigan]

${ }^{74}$ MacGuigan, ibid at 33. [emphasis in original] 
satisfaction. $^{75}$ Furthermore, there is a lot of evidence showing the mental consequences of the lack of intimacy, such as low self-esteem or depression. ${ }^{76}$

The necessity of having to suppress the need for sexual intimacy is one aspect of the problem of the lack of comprehensive contraception options. The other aspect, mentioned earlier. is the anxiety associated with the risk of pregnancy. NFP. for instance, has been associated by its users with feeling more tense, rcstlcss. anxious and less relaxed. ${ }^{17}$ It seems that it is not only the suppression of intimacy, but also, the way this intimacy, the quality of sexual life. is influenced by the fear of pregnancy, which results in the anxiety. The fear of pregnancy will appear when a couple feel they are not capable - financially or emotionally - to take care of another child. This fear might result, especially in the case of women. in the more general resistance and "negative attitudes towards sexuality and toward ... partners." ${ }^{78}$ which could be prevented by employing effective contraception.

There also exists the possibility that one of partners. because of the fear of pregnancy or because the other partner resists sex, could turn to other means or to other partners to satisfy the unmet need for sexual intimacy, and take advantage of ways that are not associated with the fear of pregnancy. This could be potentially harmful for a marriage, and. could, perhaps, be prevented by the accessibility of a wide range of contraceptive choices.

\section{Stigmatisation of sexuality}

Besides making sterilisation inaccessible to Polish people, the criminalisation of this method has also another effect. By criminalising a method of contraception, the message is being sent that there is some moral stigma, or at least some negative evaluation to be attached to its

\footnotetext{
${ }^{75}$ Several studies are cited in M.P. McCabe, "The Interrelationship Between Intimacy, Relationship Functioning, And Sexuality Among Mend and Women in Committed Relationships" (1999) 8:1 Can. J. Human Sexuality 31 at 31.

${ }^{76}$ See e.g. M.R. West et al., "Anxious Attachment and Self-Reported Depressive Symptomatology in Women" (1998) 43:3 Can. J. Psychiatry 294.

$\pi$ "Women's Satisfaction with Birth Control", supra note 48 at 281.

${ }^{73}$ R. Dixon-Mueller, Population Policy and Women's Rights: Transforming Reproductive Choice (Westport, CT: Praeger Publishers, 1993) at 151.
} 
practise even within the context of marriage. We can point to two examples of how such stigmatisation could be harmful.

First of all, a person who undergoes sterilisation - either illegally in Poland or legally in another country - may be inclined to think that she has done something morally bad. Since sterilisation is a criminal offence of the "deprivation of the ability to procreate," the reputation of the person may be questiuned by those who assume that if something is prohibited by the criminal code, it must necessarily be wrong. Such would be the case where a man underwent a vasectomy with praise-worthy motivation of preventing his partner from becoming pregnant when the pregnancy could threaten the partner's health or life. In this way a man could prevent his partner from undergoing tubal litigation, which is more risky and more complicated than a vasectomy. Such behaviour should be definitely seen as positive. while the stigma attached to the procedure because of its criminalisation might disrupt this positive image.

Another example concerns the fact that by stigmatising the use of a contraceptive method. there is also a message sent that there is something bad in the sexual act which involves the use of contraception even if, for instance, this act is taking place in the context of marriage. This message sustains the negative view of sexuality. which has been influenced by the Catholic tradition, and which has lead, in the opinion of Rosemary Radford - Ruether, to a "split personality toward sexuality". Ruether states:

On the level of 'super-ego', sex is disdained, feared and treated as an obscene subject. On the 'id' level, covert sexuality takes place in all sorts of places outside of marriage, often in exploitative and violent ways that are implicitly, if not explicitly, misogynist. ${ }^{79}$

On the level of sub-conscience a person experiences the need for sexual intimacy, for the satisfaction of this natural desire, since this is a natural part of a person's life. Thus, the level of sub-conscience, "id" suggests that sexual intimacy is a positive aspect of one's life, is necessary for the well-being. At the same time, culture. up-bringing or church's teaching (influencing conscience - the level of "super-ego") imposes a negative view on sexuality, represses the natural need. However, the natural instincts cannot be completely suppressed. A need for sexual intimacy, suppressed by its negative view created by external influences, might demonstrate 
itself in searching for the forms of sexual behaviour which should not be encouraged by the state and should not replace more safe, healthy, responsible, mutually respectful forms of sexual behaviour between partners in a relationship.

The message that I have been attempting to communicate in this section, concerning the harm of the denial and stigmatisation of the use of sterilisation. which may result in the disruption of the hamony of the relationship and thus contribute to the weakening of the bond between partners, has been also conveyed in the Platform for Action - the final document of the Beijing World Conference on Women in 1995 (Beijing Platform). ${ }^{30}$ The Beijing Platform. which was adopted with the participation of the Polish delegation. emphasises the importance of reproductive health and sexual health for the well-being of individuals and relationships. This document is an expression of states commitment to take steps towards guaranteeing sexual health of its citizens. "the purpose of which is the enhancement of life and personal relations"." The special emphasis is given to the ability to have "a satisfying and safe sex life". 82 the ability to control the reproductive capacity, for which access to the full range of "safe. effective. affordable and acceptable methods of family planning of [individuals ${ }^{*}$ choice ${ }^{* 83}$ is indispensable. This commitment was further confirmed during the special session of the United Nations General Assembly, which ended on 10 June 2000, with the consensus agreement on the document appraising the progress made by countries during the five years following the Beijing Conference. The Beijing Plus Five Final Outcome Document (Beijing Plus Five) ${ }^{8+}$ has also provided the countries with recommendations on how to continue and improve their progress towards the achievements of goals set out five years earlier.

\footnotetext{
${ }^{79}$ Radford Ruether, supra note 71 at 2.

${ }^{80}$ United Nations, Report of the Fourth World Conference on Women, t-15 September. 1995, UN Doc. A/CONF.177/20 [hereinafter: "Beijing Platform"].

s1 lbid para 94.

s Ibid.

${ }^{83} \mathrm{lbid}$.

${ }^{34}$ United Nations, Report of the Ad Hoc Committee of the Whole of the twenty-third Special session of the General Assembly, A/S-23/10/REV.I (SUPPL. No. 3), online: Division for the Advancement of Women Webpage <http://www.un.org/womenwatch/daw> (date accessed: September 18, 2000), para. $107 \mathrm{~g}$ ter [hereinafter: "Beijing Plus Five"].
} 
Once again, it should be emphasised here that, just like the two above mentioned documents, my argument is not meant to promote promiscuity, infidelity, absolute sexual freedom or separation of love and commitment from sexual intimacy. Rather, it is to demonstrate how the criminalisation of sterilisation, just as it would happen in the case of criminalising other means of contraception, can be harmful for individuals and relationships, because of the way it interferes with sexual intimacy and scxual hcalth of a couple. From the point of view of an individual person:

Sexual health is fundamental to the development of one's full human potential, to the enjoyment of human rights and to the overall sense of well being."s

And from the point of view of the well-being and stability of a relationship or marriage. sexual intimacy, free from the fear of unwanted pregnancy, is very important for the enhancement of the relationship. for its stability, allowing the couple to express their love and satisfy their need for intimacy.

\section{Denying alternatives to abortion}

In the introductory chapter, it has been pointed out that in Poland abortion is not available to end pregnancy that is unwanted due to the difficult life situation of parents, their social or economic hardship. The goal of criminalising abortion has been to eliminate this procedure. The government has been obliged to report every year how the law, by which the criminal ban on abortion was introduced, has been implemented in practice. ${ }^{86}$ The government, thus, has been obliged to report, among other facts, the number of abortions performed in a given year in Poland, both legally and illegally. The number of abortions reported by government has been very low - lower than 400 a year, of which only about 50 were the illegally performed procedures. ${ }^{87}$ These numbers have been interpreted by the Polish government as a great success of the restrictive law. However, in the opinion expressed by those who have been working in the

\footnotetext{
ss HERA (Health, Empowerment, Rights \& Accountability), "Sexual Health" in Women's Sexual and Reproductive Rights and Health Action Sheets, (published by HERA, copies available from HERA Secretariat c/o International Women's Health Coalition, NY, U.S.).

${ }^{86}$ Act on Family Planning, supra note 30, Art. 9.

${ }^{87}$ K. Montgomery, "365 Aborcji rocznie?" ("365 Abortions per year?") Gazeta Wyborcza (15-16 April 2000).
} 
area of reproductive rights and health in Poland, such as the staff of the Federation for Women and Family Planning, the government is not capable of estimating the real numbers of illegally performed abortions. ${ }^{88}$ Although the exact numbers are not known, they are said to be significantly greater than those given by government, in view of the high rates of abortion noted before the restriction. In support of such claims, the following facts are usually invoked: the existence of numerous advertisements of abortion services in newspapers and ancedotal data from women undergoing illegal abortions. ${ }^{99}$

This situation accords with opinions, which have been often expressed in various fora. that abortion rates in a country do not fully depend on its legal status. Still, to some extent. the restriction must influence people's behaviours. However, delegalisation of abortion results to a high extent in driving this service underground. ${ }^{90}$ It has been estimated. for instance, that " 20 million of the 46 million abortions performed annually world-wide occur in countries with highly restrictive abortion laws. ${ }^{.91}$ while the lowest rates have been noted in countries where abortion is legal, but, at the same time, the level of use of modern contraception is very high."

High rates of abortion in Poland before 1991 have been mostly attributed to the fact that access to family planning services and modern contraceptives was very limited under the pre1989 communist regime, making abortion a method of family planning, instead of a last resort. ${ }^{93}$ The inference that has been made on the basis of data like this is that the most effective and the most realistic way of decreasing the number of abortion is to provide the society with the wide range of safe, effective and affordable modern contraceptives. ${ }^{94}$

\footnotetext{
ss "Slepy raport" ("Blind Report") Gazeta Wyborcza (22 September 1999).

89 "Czy statystyka jest wiarygodna: Co dal zakaz aborcji" ("Are Statistics Reliable: What Has the Restriction of Abortion Law Achieved") R=ecspospolita (15 April 2000) Section: kraj.

${ }^{\circ} \mathrm{H}$. Honkanen \& G. Benagiano, "Reproductive Health in Eastern Europe: An Overview and the Challenges Ahead" in WHO Scientific Working Group on Reproductive Health Research, ed., Towards Better Reproductive Health in Eastern Europe: Concern. Commitment and Change (Budapest: CEU Press, 1999) I at 5 [hereinafter: Towards Better Reproductive Health in EE].

91 "Abortion in Context: United States and World-wide" (1999) Issues in Brief Series No. $I$ at 3.

9. Ibid.

${ }^{93}$ M. Okolski, "Abortion and Contraception in Poland" (1983) 14 Studies in Family Planning 263 at 271.

9i J. J. Rossoff "The Politics of Birth Control" (1988) 20 Family Planning Perspectives 312 at 318.
} 
Sterilisation, as it has been argued at the beginning of this section, could fulfil the expectation of people in this regard very well. Thus, the fact that sterilisation is illegal and inaccessible prevents, to some extent, a decline in Polish abortions rates. In this respect, the harm of criminalising sterilisation is two-fold. First, a lot of people who would take advantage of this mean of contraception will be forced to turn to abortion. In a lot of cases, they would prefer to avoid abortion, and, in fact, could avoid it, by undergoing sterilisation. The sccond aspect of the deprivation of safe and effective sterilisation, is that it not only "forces" some individuals to undergo abortion, which might be for them a less acceptable option than contraception. but it might also result in the risks associated with illegal abortion. since, by delegalising it, the state has lost control over the quality of this service. Such effect will be most severe on low-income people. who will not be able to access better quality underground abortion services, and may risk botched abortions performed by unqualified providers.

This form of harm has also been emphasised in the Beijing Platform and the Beijing Plus Five. The failure to fully implement the objective of "reduc[ing] the recourse to abortion through expanded and improved family-planning services" set in the Beijing Platform ${ }^{95}$ has been pointed out and stressed in the Beijing Plus Five. ${ }^{96}$ Furthermore, the obligation of governments to strive for the achievement of this goal by providing expanded family planning services has been reaffirmed. ${ }^{97}$

\section{Coerced parenthood}

Inaccessibility of sterilisation in Poland needs to be considered together with such factors as: the outlawing abortion, the deterioration of affordability of oral contraceptives (because of the lack of support for the provision of contraceptives from the government) or difficulties in access to various contraceptive options, which might take place in more remote, rural areas as well as the fact that some couples might be prevented from using other affordable contraceptives,

\footnotetext{
95 "Beijing Platform", supra note 80 para. 8.25. "Beijing Plus Five", supra note 84 para. C 9. (Obstacles in the critical area "Women and Health").

96 "Beijing Plus Five", ibid. para. $107 \mathrm{i}$.

${ }^{97}$ lbid.
} 
because of their side-effects or health risks. All of these factors combined can result in enforced child-bearing in the case of an unwanted pregnancy in Poland. The critics of the term "unwanted children" always stress that all children are a miracle and should be cherished and valued, and thus, such name is inappropriate, as suggesting some negative connotation. ${ }^{98}$ However, the reality is that for some couples, the birth of another child might be far from being miraculous. If their life situation - financial, social or familial - was different at the time, they would probably welcome the birth of a child with happiness and pride. The harm of denying parents effective and safe contraception at the time when they most need it then, is that they may not experience the wonderful miracle of having a wanted and expected child. had they had a chance to have a child in more favourable circumstances. Certainly, the option of giving the "unwanted" child up for adoption in cases of enforced parenthood should be mentioned here; however. again. not every couple will decide to do that. because of the uncertain future of the parentless child. and the general social stigma attached to those who give up infants for adoption. ${ }^{99}$ It is for the advantage and well-being of children to be born in an atmosphere of love and expectation.

The need to use effective and safe contraception is the result of feeling responsible for the well-being of the existing family. Most parents limiting the size of their family have the welfare of their children, as well as that of their partners, in mind. They decide that having more children would mean they would not be able to give as much of their time and care to the children they already have, which, in turn, could harm the children's emotional, intellectual and social development. Another harm could result from the fact that the parents themselves would not have enough time for each other, for spending time on couple-oriented activities, and for giving each other support. The lack of this opportunity might be harmful for the relationship, and, thus, also, for the whole family. For this reason, the overall harm of coerced parenthood is that it

\footnotetext{
${ }^{98} \mathrm{~J}$. Salij, "Birth Control from the Point of View of Catholic Ethics" in D.J. Roy et al., eds., Medicine, Ethics and Law: Canadian and Polish Perspective (Montreal, QU: Center for Bioethics, Clinical Research Institute of Montreal, 1991) 211 at 217.

"W. Nowicka, "Komentarz biezacy" ("Commentary") (Spring 2000) in Federacja na Recz Kobiet i Planowania Rodziny Biuletyn 2(15)/2000 (Newsletter v.2, year 2000 published by the Federation for Women and Family Planning) at 1, (available from FW\&FP, online: Federation Homepage <http://www.waw.pdi.net/polfedwo>).
} 
often deprives couples of the capability to take proper care of their family, which might be very frustrating for those who are trying to be responsible parents and partners.

Text of the General Comment 21 entitled "Equality in Marriage and Family Relations" accepted by the Committee Against Discrimination of Women tersely summarises the nature of benefits that the family can be availed of if contraceptive options are limited:

23. There is general agreement that were there are freely ayailable appropriate measures for the voluntary regulation of fertility. the health. development and well-being of all members of the family improves. ${ }^{100}$

The amount of attention, time and care which parents can devote to children will greatly influence their well-being and development - social, intellectual and emotional. The more children the family has, the less attention and care children might be able to receive from their parents. It will especially make a difference with regard to already big families. It will be a great difference whether parents have to take care of. for instance. four, as opposed to. seven children. Sterilisation can give a guarantee that the well-being of the existing family will not be jeopardised by future unwanted pregnancies.

\section{Implications for the status of women}

Aside from these general social and family harms, enforced parenthood or the deprivation of the means to avoid recourse to abortion have a particular impact on the lives of women. In spite of attaining formal legal equality, women in Poland still carry more burden and responsibility for reproduction and child-rearing. First of all. it is they who undergo the burden of pregnancy and child-bearing. Furthermore, the reality of women in Poland is, that, despite their formal emancipation, which took place under the Communist regime, and resulted in a lot of women working outside of the home, the responsibility of taking care of children and the home, is still held in the Polish society and Polish culture as the woman's task. ${ }^{101}$ Whenever home or

\footnotetext{
${ }^{100}$ Committee on the Elimination of Discrimination Against Women (CEDAW), Equality in Marriage and Family Relations, General Recommendation 21:: 04/02/94, para. 23 [hereinafter: GR 2l].

${ }^{101}$ E. Zielinska \& J. Plakwicz, "Strengthening Human Rights for Women and Men in Matters Relating to Sexual Behavior and Reproduction" (1994) 5:3 J. Women's History $9 \mathrm{l}$ at 96.
} 
children are neglected, it is a woman, who is blamed for that fact and not her partner. For this reason, women have much more to lose, if they are not able to control their fertility. ${ }^{102}$

Besides the aspects described above, there are also some other aspects of the denial of sterilisation for women. The first I would like to mention here is that, for a woman, the inability to control her fertility might radically limit her access to education, employment, career. and not aliow her to pursue the path of life she would have chosen. Since, as it was pointed above, the burden of child-bearing and child-rearing falls mostly on women, this aspect of restricting the ability to shape one's own life, has usually not been considered with respect to men. The following scenario can be invoked. A couple already has two or three or even more children. and the woman has decided to stay at home and take care of the small children. However. she has always planned to be able to go back. or maybe to start work or to continue education. after the children have grown. Her plans might never be realised if she is not able to use safe and effective contraception after giving birth to the last child she and her husband or partner wished to have. ${ }^{103}$

One note is necessary at this point. A recurring theme in the statements of reactionary politicians and some Romar Catholic officials is that those who stress the importance of a woman having a professional career or being involved in other social activities, devalue motherhood and cause harm to those women who choose to stay at home and take care of children. ${ }^{104}$ However, this misrepresents the position of feminists. These are not attempts to prefer one choice - career or motherhood - over another; and for good reason. First, such a comparison should never be made in the abstract, without taking into consideration the context of a particular woman's life. Second, in any case, the choice of what is more important for a woman, either in general or at a particular moment of her life, should be made by this woman herself. And finally, there is really no need for a woman to make such a choice, because it is possible to realise both of these goals, if a woman is able to choose how her life is shaped. If

\footnotetext{
${ }^{102}$ M. F. Fathalla, "Fertility Control Technology: A Women - Centred Approach to Research" in G. Sen, A. Germain \& L.C. Chen, eds., Populations Policies Reconsidered: Health, Empowerment, and Rights (Boston, Massachusetts: Harvard School of Pubic Health, 1994) 223 at 226 [hereinafter: Population Policies Reconsidered]. ${ }^{103}$ The scenario with reversed gender roles is, unfortunately, much less probable in Poland.
} 
family planning methods are available to her, she has greater control over her life. It is often forgotten that men are usually not put in the situation where they have to give up all their life plans, drop everything and stay at home and take care of children. This has usually not been expected from men, and it should be possible for a woman to not be forced into this situation, but to be able to choose it for herself.

The acceplance and availability of sterilisation would also promote a better understanding of the role of both partners in family planning and birth control. Sterilisation is one of the two contraceptive methods available to men. By having the choice to undergo a vasectomy, men can take responsibility for family planning and its consequences. This is important. since family planning responsibilities have been traditionally assigned to women. and to allow and to encourage men to take on some of these responsibilities could help them understand fully the importance and consequences of these issues for women. It can encourage men to adopt more responsible sexual behaviours, and may contribute to their greater involvement in the life of the family.

The importance of the involvement of men in family planning has been also emphasised in the documents adopted by governments during the Beijing Conference and the International Conference on Population and Development in Cairo. The Cairo Programme of Action in paragraph 4.24 states that in order to progress towards the achievement of equality between men and women, it is necessary "to encourage and enable men to take responsibility for their sexual and reproductive behaviour and their social and family roles." 105

Inaccessibility of vasectomy procedures does not allow men to, for example, take part in making sure their partner's health is protected in those cases where the pregnancy constitutes a danger to woman's health. In this way men could benefit the welfare of the family, and not put their partners to any risks associated with sterilisation. In the Cairo Programme, in paragraph 4.27, the countries undertook an obligation that:

\footnotetext{
${ }^{104}$ See e.g. "Prymas na Boze Cialo" (Primate on Corpus Christi) Gazeta Wyborcza (23 June 2000). The Primate (Head) of the Catholic Church in Poland was quoted as saying that feminist ideology is degrading for women and makes them feel inferior.
} 
Special efforts [w]ould be made to emphasise men's shared responsibility and promote their active involvement in responsible parenthood. sexual and reproductive behaviour, including family planning; ...; prevention of unwanted and high-risk pregnancies ... ${ }^{106}$

It has been noted that:

Across the regions, men have sometimes shown more interest in family planning than is usually assumed by service providers and policy makers. ${ }^{107}$

The inaccessibility of sterilisation denies men the choice to take on further family pianning responsibilities.

Yet, another aspect of the legal status of sterilisation in Poland is that it has been singled out from all other contraceptive methods and criminalised. One possible explanation is that it is distinguished by its permanent nature. As the criminal provision states. it is a permanent "deprivation of the ability to procreate". The question, then. is whether this ability has any special significance in the Polish society and. for this reason. needs a special protection. Some Polish authors have explained it in this way. ${ }^{108}$ They point to the stereotypical image of a Polish woman - Matka Polka - a caring mother that sacrifices herself for the welfare of the family. children, a husband, and the nation. This is not a negative picture in itself. The values which it embodies are naturally appealing and the concept is an expression of admiration. However. the value of playing such a role will only be appreciated by a woman if this role is voluntarily chosen by her, and not enforced on her by the society as the only way she can earn societal recognition. The biological fact that a woman is able to bear children should not delimit or determine her utility for the society; as a man's ability to inseminate does not determine his societal utility. Just as in the case of a man, a woman should be appreciated for her achievements in any sphere of social life regardless of whether she is married or not. has children or not, is a good mother or not.

\footnotetext{
${ }^{105}$ United Nations, Report of the International Conference on Population and Development. Cairo, 5-13 September 1994, UN Doc. AVCONF. 171/13, para. 4.24 [hereinafter "Cairo Programme"].

100 "Cairo Programme", ibid. para. 4.27.

${ }^{107}$ A. Germain, S. Noworojee \& H.H. Pyne, "Setting a New Agenda: Sexual and Reproductive Health and Rights" in Population Policies Reconsidered, supra note 102 at 39.

${ }^{108}$ See e.g. A. Kulczycki, "Abortion Policy in Postcommunist Europe: The Conflict in Poland" (1995) 2I Population \& Development Rev. 471 at 490 . See also "Sterilisation and its Legal Regulation", supra note 38 at 24.
} 
Putting on the pedestal the ability to procreate, by criminalising its voluntary deprivation by a woman, sends a message that there are no other values in a woman's life which could be more important than her ability to procreate, even if she already has children. In this way, her capacity to procreate is in fact, transformed into a duty to maintain the ability to procreate. ${ }^{109}$ And since such a duty would limit the woman's ability for the full participation in other spheres of life, she would be pronc to considering this ability as a burden rather than as a positive feature. if she did not have the choice to limit it by, among others. the access to sterilisation.

Katarina Tomasevski has invoked the fact that. as early as 1983. the European Parliament has taken a resolution which has stressed that:

[F]amily policy cannot in any way stand in the way of progress towards ensuring that women have their own non-derivative rights. ${ }^{10}$

The harm of "family policy" which creates the duty to maintain fertility is that the value of a woman is determined on the basis of her marital status, her number of children and whether she is a "good" mother and a wife. despite her own professional achievements. If so. a woman. who has chosen a different path of life will be always looked at as a woman of the second category. Again, I have to emphasise that this is not to say that a woman who chooses to remain at home is a woman of a second category. "' It is only to say that women will never achieve full equality with men, if, when they pursue a life-style which is valued when pursued by a man, would be seen as "bad" women, on the basis that they do not fit into the stereotype of Matka Polka.

\section{Moral harm and Health implications}

The denial of sterilisation has also some implications in the moral sphere, as imposing the one, and the only justified morality and questioning the moral choices made by others. There are also health implications for those who, by not being able to access sterilisation must employ less

\footnotetext{
${ }^{169}$ See e.g. J. Bridgeman \& S. Millins, Feminist Perspectives on Law: Law's Engagement with the Female Body (London: Sweet \& Maxwell, 1998) at 198.

${ }^{110}$ Eur. Parl. Res. (9 June 1983), reprinted in H.R. Information Sheet No. 13 Europe, Council of Europe Directorate of H.R. Doc. H/Inf. (83) 2 at 120 (Apr. - Oct. 1983) cited in K. Tomasevski, “European Approaches to Enhancing Reproductive Freedom" (1995) 44 A. U. L. Rev. 1037 at 1041.

"II It is worth noting that the same rule should apply to a man. If a man stays at home taking care of children and not working outside of a home, he should be valued on the basis of how good he is in what he is doing.
} 
suitable means of contraception and face side-effects and health risks associated with them. These aspects of implications of the lack of access to sterilisation will be discussed in more detail when the implied harms of the decriminalisation of this procedure will be considered.

\section{Misinformation}

The last point to he made with regard to harms of the anti-sterilisation law to the potential recipients of sterilisation services, is that such law represses the public knowledge about this method. Even though the risk of the enforcement of this law is minimal, nevertheless, because of its existence and the resulting stigma, it is not a particularly popular topic of a public discussion. It also questionss the purpose of discussing its advantages, as it is not accessible anyway. As a result. some unjustified, negative stereotypes concerning this method are not being refuted and remain current, such as: that it causes impotency in men. or that it is the equivalent of castration. or that it is not accessible at all for men, ${ }^{12}$ as well as that it is very painful and more dangerous for a man than a woman. The harm of such misinformation is, among others that, if the couple decides to use sterilisation as a contraceptive method, either illegally or legally in another country, it will be, most probably a woman, not a man, who will undergo the operation. while it could be often safer and easier for a man to do it.

Harms of anti-sterilisation law for the medical profession

It is necessary to look at the Polish anti-sterilisation law also from the perspective of interests of medical profession. We can talk about two basic harms. First, we can look at this law as an interference with the freedom of medical profession. Doctors who might view this method as beneficial and being in the best interests of a patient will be prevented by the threat of criminal sanction or the loss of professional licence from performing sterilisation demanded by a patient, when this procedure might, in their opinion, be suggested by medical knowledge. Second, in the case where a physician decides to perform such operation, he is placed in a very uncomfortable position. First, a physician is taking a risk of the potential legal or professional consequences.

112 "Sterilisation and its Legal Regulation", supra note 38 at 24. 
Second, he may be stigmatised for breaching the law and thus, loose credibility among patients or colleagues. His action can be judged by some as unethical since, as noted by Rebecca Cook and Bernard Dickens: "a well-established principle of ethical conduct is that it should conform to the law," $" 13$ even though the physician might view his behaviour as acceptable according to the guidelines given him by medical ethics. Further discussion of this category of harms will take place in Chapter IV. Part C.

\section{Conclusion}

The harms that result or may result from the criminalisation of sterilisation in Poland are related to the fact that this is one of the most effective and safe methods of family planning.

Lack of effective and safe contraception, which would give the comfort of the sexual intimacy without the fear of pregnancy and, which. more generally. can have a positive influence on sexual life and health, may be harmful for the well-being of relationship. Sexual intimacy is an important aspect of the relationship, necessary for its enhancement. stability. giving the partners feelings of being loved. admired, appreciated. cared for and respected. The harms associated with the suppression of sexual intimacy in marriage might include: harms to the psychological health of partners; turning to sexual behaviours outside of marriage that are not mutually respectful, safe and responsible; in order to satisfy the unmet need for sexual intimacy. All of the above may lead to dissatisfaction with the relationship which. potentially, could be avoided if the couple had taken advantage of the safe and effective contraception.

In order for the effective and safe contraception to be truly accessible for everyone, a comprehensive variety of methods must be provided, as contraceptive needs vary depending on health conditions, age and other factors. Sterilisation might be particularly beneficial for either of the partners of a married couple with children: women in their later reproductive years and men in general, as their choices in this sphere are very limited; because they are in a position to decide that irreversibility of the method is no longer a barrier, and it does not outweigh the benefits the method gives them. 
The inaccessibility of sterilisation can mean that there has not been sufficient alternatives given to prevent recourse to abortion. It also can result in enforced child-bearing.

Furthermore, I have attempted to demonstrate the link between the lack of access to sterilisation and the ways it prevents the improvement in the status of women in Polish society. The inability of a woman to control her fertility limits her access to educational or professional development. Criminalisation of sterilisation contributes to the preservation of such stereotypes as "Matka Polka" - a woman whose only respected and valued social role is that of mother. who takes care of children and the home without help from her partner and is held responsible for any failures on this front, especially if she decides to make a career. And because it is her role and responsibility to employ methods of contraception and she is expected to drop all her plans and take care of children if she fails in this sphere. the importance. and the burden of these expectations is not appreciated by men. unless they are encouraged to get involved in them. Accessibility of vasectomy could be one way to get them involved.

Finally, in addition to the inaccessibility of this method. there are particular harms associated with the fact that this procedure is regulated by criminal law. Criminalisation per se imposes a stigma. stigma which might be associated with a person who undergoes the sterilisation procedure. as well as stigma that maintains a negative view of sexuality. One further implication of the fact that sterilisation has been criminalised is that it puts excessive emphasis on preserving fertility, implying it deserves special protection. Such protection results in imposing a duty to maintain the ability to procreate, which has the potential to turn it into a burden rather than a value.

In further parts of this work I will be returning to the harms of the criminalisation of sterilisation and discussing them from different perspectives.

\footnotetext{
${ }^{113}$ R.J. Cook \& B.M. Dickens "Ethics and Human Values in Family Planning: Legal and Legislative Aspects" in Ethics and Human Values, supra note 55, 117 at 128.
} 


\section{PART C. Perceived Harms of Legalisation of Sterilisation}

We need to look now at anti-sterilisation law from the broader perspective and consider what arguments can be raised in support of it and against the legal reform. We need to look thus, at various objections, negative features which can be ascribed to this procedure as a method of birth-control.

First of all, in the previous part of this chapter, several disadvantages of this contraceptive method were mentioned. such as its side-effects: heavier menstrual bleeding or pain. risks of a surgery and anaesthesia or a risk of ectopic pregnancy in the case of failure of the method and. finally, a potential irreversibility of the inability to procreate.

Another set of concerns about legalising sterilisation has its source in the common perceptions of this method. Some of these perception include the confusion of this method with castration (the removal of sexual organs or depriving them of their functioning) or the belief that this method causes impotence or interferes with sexual drive. These concerns should not constitute barriers to the legal reform, because they are based on misinformation or ignorance. However, one negative connotation of sterilisation - the association with, for instance. Nazi practices of coercive sterilisation ${ }^{114}$ - should be taken into account as it can invoke an argument that this method is susceptible to abuse and coercion in the degree greater than in the case of other contraceptive methods. Such argument is likely to be invoked also in view of the fact that sterilisation has been lately most often referred to in Polish media in association with coercive policies of over-populated states directed at decreasing fertility rate. Such alarming news were reported in Polish media with regard to, for instance, Bangladesh, ${ }^{115}$ China ${ }^{116}$ or India. ${ }^{117}$ The question then, is whether this potential for abuse - the possibility that this procedure could be

\footnotetext{
${ }^{114}$ See e.g. Wasek, supra note 10 at 89.

115 See e.g. B. Nizienski, "Brakujace Pytanie" (Missing Question) Rzecepospolita (24 March 1999).

${ }^{116}$ See e.g. T. Belerski, "Walka o zdrowe spoleczenstwo" (Battlle for a Healthy Society) Rzeczpospolita (24 December 1993).

${ }^{117}$ See e.g. R. Stefanicki, "Co czwarty porod w Indiach" (Every Fourth Child-birth in India) Gazeta Wyborcza (22 September 1999).
} 
provided in non-voluntary manner, imposed on unwilling patients - could outweigh the benefits it can bring, if accessed voluntarily.

Furthermore, it has been pointed out in the previous part of this chapter that this method as permanently depriving a person of the ability to procreate - would be incompatible with, for example, the concept of "Matka Polka." If, in the value system of a society, the ability to procreate was ascribed a particular place. legalisation of stcrilisation might bring concems of attacking values shared by this society, especially if this value was to be considered essential for the preservation of the society's identity. Similarly, the opposition to accessibility of this method can flow from religious morality. In Poland. the clear condemnation of sterilisation by the Roman Catholic church should be taken into account as one argument in the discussion about challenging anti-sterilisation law. We should thus. take into consideration potential perceived moral harms associated with this method as opposed to moral harms of the criminalisation of this method signalled in the previous part.

Finally, one more concern alluded to by some Polish scholars is an apprehension about the possibility that the accessibility of sterilisation on a wider scale could have significant influence on the demographic situation of a country. ${ }^{118}$ This apprehension needs to be viewed in relation to the fact that Poland has been in the last years experiencing a gradual decrease of birth rates and just recently, for the first time in the history of Poland, the fertility rate has been negative and below the generation replacement level. ${ }^{119}$

The first two concerns discussed above: health concerns and concerns about the method's susceptibility to abuse and coercion; can be referred to as micro-concerns. Such classification gives emphasis to the fact that these are concerns over how legalisation of sterilisation could influence welfare of individuals - the potential recipients of this method.

The remaining two concerns are macro-concerns. They require us to put forward a question whether the legalisation of sterilisation could negatively impact the demographic and

\footnotetext{
${ }^{118}$ See e.g. Wasek, supra note 10 at 95 . See also "Conditions of Admissibility", supra note 4 at 66.

119 "Demografia: Polakow mniej o trzynascie tysiecy. Niekorzystne Prognozy" (Demographics: Thirteen Thousands Less of Poles. Unfavourable Prognosis) Rzeczpospolita (30 December 1999) Section: kraj.
} 
economic situation of Poland or whether it could undermine the system of values shared by the Polish society in the way that would justify the retention of the existing restriction.

Both micro- and macro-concerns about the accessibility of contraceptive sterilisation can give basis for pursuing arguments against the legal reform. These arguments need to be juxtaposed with harms of the existing anti-sterilisation law.

The rights and ficcdoms which could be held to be violated by anti-sterilisation law wil! be discussed in Chapter III. The juxtaposition of harms of anti-sterilisation law with the concerns associated with legalisation of this method - identified in this Part - will be made in Chapter IV. Such juxtaposition should assist in determining whether the concerns constitute sufficient reasons to justify the maintenance of anti-sterilisation law despite its harmful effects. 


\section{CHAPTER III.}

\section{THE LACK OF ACCESS TO STERILISATION AS A VIOLATION OF HUMAN RIGHTS}

\section{PART A. Introduction}

In the previous chapter. I have identified two sets of issues. Focus of Part B was on negative implications of anti-sterilisation law on the Polish society. In this part I have attempted to draw a broad picture. identify different categories of potential harms of this law and demonstrate impact of this law on groups of society: differential impact on two genders, impact on the welfare of a family, impact on the medical profession and impact on the society as a whole. In Part $C$ the focus shifted to implied harms of making contraceptive sterilisation accessible in Poland, which could likely be reasons for retaining anti-sterilisation law and resisting the legal reform.

In this chapter I want to ask whether the alleged harms of anti-sterilisation law identified in Part B could be held as violations of the international human rights law and relevant provisions of the Polish constitutional law. It will be a two-steps process. First we need to ask whether it is possible to argue that law gives individuals protection from the harms of the existing regulation. This step will be taken in this Chapter. And second, we need to look at arguments which could be raised against the legal reform and could justify the existing restriction besides its harmful effects. The weighing of arguments for and against the reform will be made in Chapter IV.

While embarking on the mission set up for Chapter III - the analysis of protection given by international human rights law and Polish Constitutional law against harms of antisterilisation legislation, one needs to be aware that, most probably, not all of the identified harms can be directly linked to a violation of rights. However, in such a case, the harms that cannot be said to amount to rights violations, should be still considered as relevant for the weighing of arguments in favour and against of the challenge of anti-sterilisation law. 


\section{The Place of International Human Rights Law in the Polish Legal System}

Binding force of the international law provisions in the domestic legal order

The new Polish Constitution ${ }^{120}$ adopted by the Polish Parliament on 2 April 1997 and approved in the national referendum on 25 May 1997, for the first time in the history of Polish constitutionalism, contains a separate chapter - chapter III entitled "Sources of Law." This chapter in a very clear way presents what acts constitute binding sources of legal obligations in Poland and introduces the hierarchy of these sources. The sources are enumerated in Art. 87 of the Constitution. They include: the Constitution. statutes, ratified international treaties and regulations. The Constitution in Art. 91 explicitly states that a ratified international treaty following its promulgation becomes part of the domestic legal order and is directly applicable. The only exception regards non self-executing provisions. which require the enactment of specific legislation to become binding in the domestic legal order.

Place of international law in the hierarchy of sources of law

International law and Constitution - regulation in the Constitution

The Constitution is the highest law in Poland. ${ }^{121}$ In principle, all ratified international treaties are subjected to the constitutional scrutiny. In the case of conflict, the Constitution, as the highest law, must prevail. This is one of the reasons why, these international treaties which pertain to the same subject matter as constitutional provisions or pertain to the sphere of civil freedoms, rights and civic obligations, can only be ratified with the prior approval of the Polish Parliament. ${ }^{122}$ Provisions of international human rights law fall in this category.

Intemational law and Constitution - in jurisprudence

\footnotetext{
${ }^{120}$ Konstytucja Rzeczpospolitej Polskiej z dnia 2 kvietnia 1997 r. (Constitution of the Republic of Poland from April 2, 1997), Dz.U. Nr 78, poz. 483 [hereinafter. Constitution].

:21 Constitution, ibid Art. 8.

I2: lbid. Art. 89.
} 
It is important to note that, although in Polish legal system, as stated above, the international treaties have a lower status than the Constitution. Constitutional Tribunal and Polish courts, when interpreting constitutional principles, often refer to the provisions of treaties - which are their equivalent - and to the way these provisions are interpreted in international jurisprudence. ${ }^{123}$ It can be assumed that Poland will not ratify treaties that are not compatible with the provision of the Polish Cunstitution, being the highest law in Poland. ${ }^{24}$ However. once ratified, a treaty and international jurisprudence developed under the treaty will influence the way the constitutional principles are interpreted in the domestic legal order.

\section{International law and domestic statutes - regulation in the Constitution}

There are two categories of international treaties - those that. as indicated above. require prior approval of Parliament before their ratification and those that can be ratified without such approval. The former, through the ratification in the "parliamentary procedure" acquire higher position in the legal order than domestic statutes. As provided in Art. 91(2), in the case of conflict between domestic legislation and the provisions of the international treaties ratified with the prior approval of Parliament, the provisions of the treaty prevail. The place of the latter category - treaties that have not gone through the "parliamentary procedure" - is not explicitly regulated by the Constitution. From the interpretation a contrario of Art 91(2) we can infer that their status is either equal or lower to that of domestic legislation. This question still needs to be clarified in practice.

\section{Intemational law and domestic statutes - in jurisprudence}

Prior to the adoption of the new Constitution in 1997, the place of the international law was not normatively regulated. However, even before 1997, international law provisions have been treated as directly binding on the state institutions in the jurisprudence of the Constitutional

\footnotetext{
${ }^{19}$ See. e.g. Judgement of the Supreme Court of 18 August 1999, II CKN 321/99, OSNC 2000/3 poz.49. The judgment referred to Art. 8 of the European Convention, infra note 131 and Art. 17 of the Political Covenant, infra note 127, as well as the jurisprudence of the European Court of Human Rights, when interpreting Art. 47 of the Polish Constitution. See also: Judgement of the Polish Constitutional Tribunal of 19 May 1998, U 5/97.
} 
Tribunal. For the first time, in 1992, ${ }^{125}$ the Constitutional Tribunal invalidated a statute on the basis that it was incompatible with Constitution of $1952,1^{126}$ as well as, with provisions of the International Covenant on Civil and Political Rights. ${ }^{127}$ The Constitutional Tribunal has also often referred to international law, not to invalidate domestic provisions, but to give them a broader interpretation and expand their scope in accordance with international standards. ${ }^{128}$ In doing so, the Tribunal invoked the principle of the democratic rule of law ("Rechtsstat" ${ }^{\text {"199) }}$ which, in the view of the Tribunal, requires, that the democratic country observes standards of the human rights protection which are recognised by the international community. ${ }^{130}$

\section{Provisions of the Polish Constitution Pertaining to the Human Rights Protection}

Human rights provisions occupy a prominent place in the Polish Constitution. They are regulated in Chapter II entitled "Freedoms. Rights and Obligations of a Person and a Citizen." Fifty seven articles (Art. 30 through 81 ) regulate freedoms and rights as compared to five (Arts. 82-86), which provide with civil obligations. Rights and freedoms are grouped under the following headings: general principles (Arts. 30 - 37); personal (private) rights and freedoms (Arts. 38 - 56); political rights and freedoms (Arts. 57 -63); and economic, social and cultural rights (Art. 64 - 76). Articles 77 through 81 concern procedural matters. The human rights provisions of the Polish Constitution are greatly influenced by international human rights

\footnotetext{
${ }^{124}$ Polish Parliament considering the ratification of a treaty which is incompatible with a Polish constitution might consider amending a constitution to allow for the ratification of that treaty.

125 Judgment of the Constitutional Tribunal of 7 January 199, K 8/91, 1992 (I) OTK 76 at 84.

130 Konstytucja Polskiej Rzeczpospolitej Ludowej = dnia 22 lipca 1952 r., Dz.U. $1976 \mathrm{Nr} 7$ poz. 36 with amendments [hereinafter: Constitution 1952].

${ }_{127}$ International Covenant on Civil and Political Rights, G.A. Res. 2200 (XXI), 21 U.N. GAOR Supp. No.60 at 52, U.N. Doc. A/6316 (1966) [hereinfter: Political Covenant]. Poland ratified the Political Covenant on March 3, 1977, Dz.U. $1977 \mathrm{Nr} 38$ poz. 167.

${ }^{128}$ See e.g. Judgment of the Constitutional Tribunal W 3/93 and Judgment of the Constitutional Tribunal of 29 September 1993, K 17/92, 1993 (II) OTK 297 at 309. Both the decisions referred to the European Convention, infra note 131 .

139 'Rechisstaat' - the principle developed in the German legal doctrine. It refers to the principle of the 'state based on the rule of law.' This is a complex concept, which encompasses several principles - pertaining both to formal requirements (rule of law in the formal meaning: that the state institution act according to the law), as well as some material requirements (such as: due process of law, pacta sunt servanda, division of powers, and others). See Stawecki \& Winczorek, supra note 32 at 171-172.
} 
treaties, mainly by the Convention for the Protection of Human Rights and Fundamental Freedoms $^{131}$ (European Convention), the International Covenant on Civil and Political Rights ${ }^{132}$ (Political Covenant) and the International Covenant on Social, Economic and Cultural Rights ${ }^{133}$ (Economic Covenant), all ratified by Poland. Thus, the international human rights provisions that will be invoked further in this chapter will find their equivalent in the provisions of Polish Constitution.

We can point to the following articles of the Constitution. which are relevant for further discussion in this chapter: Art. 68 - the right to the protection of health. Art. 47 - the right to legal protection of private and family life and decisions about personal (private) life. Art. 32 the right to equality and non-discrimination and Art.33 - the right to equality between genders. Furthermore, Art. 31 of the Constitution provides a general clause concerning limitations that can be imposed on the rights and freedoms guaranteed in the Constitution.

\section{Conclusion - Polish Law and International Law}

To sum up ideas from previous sections, we can say that provisions of international human rights law have an established position in the Polish legal order. They become directly binding upon their ratification and promulgation. By invoking international human rights provisions we can challenge domestic statutes conflicting with international law. In the case of a treaty provision which has its equivalent in the Polish Constitution (such is the case of provisions which will be discussed in this work to challenge anti-sterilisation law) we should invoke both provisions - domestic and international - together. A treaty and international jurisprudence developed under this treaty should inform our interpretation of the provisions and principles of the Polish Constitution. This method of interpretation can be justified and supported by reference

\footnotetext{
${ }^{130}$ See e.g. Judgment of the Constitutional Tribunal of 24 June 1997, $\mathrm{K} 21 / 96$ (decided prior to the coming into force of the new Constitution 1997).

${ }^{131}$ Convention for the Protection of Human Rights and Fundamental Freedoms, 4 November 1950, 213 U.N.T.S. 221 at 223, ETS No. 5 hereinafter. European Convention]. Ratified by Poland on January 19, 1993, Dz.U. $1993 \mathrm{Nr}$ 61 poz. 284-286.

132 Political Covenant, supra note 127. Ratified by Poland Poland on March 3, 1977, Dz.U. 1977 Nr 38 poz. 167.

${ }^{133}$ International Covenant on Social, Economic, and Cultural Rights, 16 December 1966, 999 U.N.T.S. 3 art. 12 [hereinafter Economic Covenant]. Ratified by Poland on March 3, 1977, Dz.U. 1977 Nr 38 poz.169.
} 
to the principle of the democratic rule of law (rechtsstaat) which, in the new Constitution, is embraced in Art. 2. ${ }^{134}$

The language of international human rights law can be a powerful advocacy tool. It can challenge regressive domestic legislation and practices. It has a power of authority. This manifests itself in decisions of judicial or quasi-judicial international bodies which have prompted reform of legislation in many countries. For this reason. the main focus of this work will be on provisions of international human rights law.

\section{Classification of harms for the purpose of legal analysis}

The goal of the following parts of this chapter is to explore whether the harms discussed in the previous chapter could be protected by provisions of the international human rights treaties. For the purpose of this analysis, I have grouped the harms into three categories.

The first category encompasses the implied harms to health interests of a person. By health interests I understand interests of an individual in controlling his or her health and in accessing (whether by public or private means) the full range of goods and services required to promote his or her individual health and well-being, assuming that we can understand "health" in this context as encompassing not merely the medical definition of health as an absence of illness or injury, but a broader conception that takes into account mental, emotional and even sexual well-being. Among the harms discussed in the previous chapter, such issues as: potential harms to the mental health of an individual caused by the interference with the sexual intimacy (which can result from the lack of effective and safe contraception), health risks of other contraceptive methods (used in the place of sterilisation) or health risks of pregnancy or illegal abortion, as well as the general interference with sexual health by limiting contraceptive choices fall into the first category of health interests. The analysis of whether harms to these interests could amount to the violation of the right to health under international law will be discussed in the section entitled The right to health.

\footnotetext{
${ }^{134}$ Constitution, supra note 120, Art. 2. Art. 2 reads as follows: "Republic of Poland is a democratic state based on
} the rule of law, which promotes the principle of social justice." 
The second category is created with an initial assumption that the human rights violation with regard to access to sterilisation could also be established even if, or despite of, the health concerns of the lack of access to this service. Such harms as: the inability to choose the contraceptive method of one's choice, or the interference with sexual life resulting from the anxiety about the potential pregnancy, or the enforced childbearing or parenting, can be treated together as the interference with the liberty interests of an individual. In looking for protection of liberty interests I will turn to the right to respect for private and family life in section The right to respect for private and family life.

Finally, when discussing harms, the link between anti-sterilisation law and a status of women has been outlined. Such issues as an unequal burden of childbearing and child-rearing. which falls upon women, their inability to realise life-plans in the case of unwanted pregnancy were signalled. These will be discussed more in-depth in section The right to equality. where the question to consider will be whether the circumscription of contraceptive choices could give rise to claims of women under the right to equality and non-discrimination. 


\section{PART B. The Right to "Health"}

In the previous chapters I have identified the following health harms which could potentially result from the lack of sterilisation as a contraceptive option: the health risks associated with other contraceptive methods, employed in the place of sterilisation; the possibility that the unsatisfied need for the sexual intimacy (resulting from the anxiety associated with the risk of pregnancy) could lead to some psychological problems; and finally, the general interference with sexual life and sexual well-being of partners. In this section I want to discuss whether it would be possible to claim that by exposing individuals to those health risks the state violates international provisions, which pertain to the right to health.

The invocation of the right to health in the international law can meet with serious difficulties resulting from the lack of clarity concerning its scope and content which. in turn flows from the indeterminacy of the term "health" itself, as well as the weakness of the mechanisms provided to enforce this right. ${ }^{135}$

The right to health is guaranteed in Article 12 of the Economic Covenant, which, read together with Article 2, urges countries to make a continuous effort towards the full realisation of "the right of everyone to the enjoyment of the highest attainable standard of physical and mental health". ${ }^{136}$ Another instrument that invokes the right to health is the Convention on the Elimination of All Forms of Discrimination against Women (Women's Convention). ${ }^{137}$ Its Article 12 reads as follows:

1. States parties shall take all appropriate measures to eliminate discrimination against women in the field of health care in order to ensure. on the basis of equality of men and women, access to health care services, including those related to family planning.

2. Notwithstanding the provisions of paragraph $l$ of this Article States Parties shall ensure to women appropriate services in connection with pregnancy, confinement and the post-natal period, granting free services where necessary, as well as adequate nutrition during pregnancy and lactation. ${ }^{138}$

\footnotetext{
${ }^{135}$ See e.g. B.C.A. Toebes, The Right to Health as a Human Right in International Law (Antwerpen: Intersentia, 1999) at 4 (Ibid. at 20-25, See also ibid. at 167 and 346).

${ }^{136}$ Economic Covenant, supra note 133.

${ }^{137}$ Convention on the Elimination of All Forms of Discrimination against Women, GA Res. 34/180, UN GAOR, 34th Sess., Supp. No.46 at 193, UN Doc.A/39/45 (1979) (entered into force, Sept. 3, 1981) [hereinafter Women's Convention].

${ }^{138}$ lbid. Art. 12.
} 
The task of analysing whether the health harms identified above could amount to a violation of these provisions requires to grapple with two issues. First question is whether these health harms would fall within the scope of the right to health. And, second, whether the right, with regard to these harms, could be legally enforceable against the state.

\section{The Concept of Health}

The conceptual and enforcement difficulties with the right to health have recently prompted the Committee on Economic, Social and Cultural Rights (Economic Committee) ${ }^{139}$ to proclaim General Comment 14 interpreting Art. 12 of the Economic Covenant. ${ }^{1+0}$ General Comment 14 is extremely useful for understanding the degree to which one can rely on this provision for claiming violations.

The Committee refers to the definition adopted by the World Health Organisation. which describes health as: "a state of complete physical, mental and social well-being and not merely the absence of disease or infirmity, $" 1+1$ suggesting that this is the direction the interpretation of the term health should follow in the context of Art. 12 of the Economic Covenant. Another indication of the broad understanding of the right to health can be found in the reference to the definition of reproductive health in the Cairo Programme of Action and Beijing Platform for Action. The definition of reproductive health in these documents reads:

Reproductive health is a state of complete physical, mental and social well-being and not merely the absence of disease or infirmity, in all matters relating to the reproductive system and to its functions and processes. Reproductive health therefore implies that people are able to have a satisfying and safe sex life and that they have the capability to reproduce and freedom to decide if, when and how often to do so. Implicit in this last condition are the right of men and women to be

\footnotetext{
139 The Committee on Economic, Social and Cultural Rights (CESCR) was established in 1987 to supervise compliance by states parties with their obligations under the Economic Covenant. In many respects it works in the similar way as the Human Rights Committee (HRC) (created to supervise the work of the Political Covenant), although it is not authorised to consider individual communications. It can only review reports of the states parties and enunciate concluding observations and general comments.

${ }^{1+0}$ CESCR, General Comment 14, The Right to the Highest Attainable Standard of Health: 0t/07/2000. E/C. 12/2000/4, online: United Nations High Commissioner for Human Rights Webpage (Treaty-bodies database) <http $/ /$ www.unhchr.ch> (Treaty Bodies Database, date accessed: September 21, 2000) [hereinafter: GC 14]. ${ }^{1+1}$ Constitution of the World Health Organisation in: Basic Documents, $39^{\text {th }}$ ed (Geneva: World Health Organisation, 1992), referred to in GC It, ibid. para. 4.
} 


\begin{abstract}
informed and to have access to safe, effective, affordable and acceptable methods of family planning of their choice, as well as other methods of their choice for regulation of fertility which are not against the law ....It also includes sexual health, the purpose of which is the enhancement of life and personal relations, and not merely counselling and care related to reproduction and sexually transmitted diseases. ${ }^{142}$
\end{abstract}

These references posit that health should be understood in a broad sense not limited solely to physical health, but also pertaining to psychological and social well-being and to sexual and reproductive health. One of the elements, which is necessary for the achievement of reproductive health. and, thus, health in general, is access to comprehensive range of contraceptive choices, and the ability to freely choose the method of contraception that best suits one's needs. The question still to be resolved is whether it is possible to claim the violation of the right to health with regard to all the elements suggested in this broad concept of health.

\title{
Enforceability
}

The Economic Committee states in the General Comment 14 that the right to health provided in Art. 12 of the Economic Covenant encompasses both freedoms and entitlements. and one of the entitlements is the right to control one's health and body. which includes sexual and reproductive freedom. ${ }^{1+3}$ The Committee indicates that Art. 12(2)(a) specifically "may be understood as requiring measures to improve sexual and reproductive health, including access to ... safe, effective, affordable and acceptable methods of family planning of [one's] choice." ${ }^{\text {1+4 }}$ Furthermore, the Committee in the Comment also employs a tripartite typology of obligations that flow from the right to health - the obligations to: (1) respect, (2) protect and (3) fulfil. ${ }^{145}$ Such typology has been developed in scholarly writing and subsequently adopted by the international bodies. ${ }^{1.6}$

These recommendations could lead to the conclusion that anti-sterilisation law in Poland is a violation of the right to health, as far as it violates the obligation to respect by interfering

\footnotetext{
142 "Cairo Programme", supra note 105, para. 94. "Beijing Platform", supra note 80, para. 7.2.

${ }^{143}$ GC 14 , supra note 140 , para. 8.

it Ibid., para. 14.

${ }^{145}$ GC 14, supra note 140 para. 33.

${ }^{146}$ See e.g. CEDAW, General Recommendation 24, Women and Health (Article 12), CEDAW/C/1999/

IW.G.ILWP.2/Rev.I. para. 14-17 [hereinafter: GR 24].
} 
with access to a safe and effective method of contraception, which is considered to be the measure leading to the improvement of sexual and reproductive health. This theory also finds support in paragraph 34 of the GC 14, which states: "States should refrain from limiting access to contraceptives and other means of maintaining sexual and reproductive health." ${ }^{~} 1+7$ furthermore, to support the state's obligation to respect the right to health of women, in its General Reconmendation 24 Women and Health the Committee on the Elimination of Discrimination against Women submitted:

14. The obligation to respect rights requires States to refrain from obstructing action taken by women in pursuit of their health goals.: ${ }^{1+8}$

One remark is necessary in this place. In the case of anti-sterilisation law in Poland, there are certain health interests infringed, which are not immediate nor physical, but. as suggested above. may still be prohibited by the right to health. Those include: harms to psychological health. emotional and social well-being and sexual and reproductive health, which may result from two circumstances: (1) the use of ineffective methods of contraception resulting in anxiety about the risk of pregnancy, or (2) from the unmet need for the sexual intimacy. Despite this risk. the argument would encounter certain difficulties. First. one can argue that. as far as the first risk is concerned, it is always possible to point to the fact that there are other contraceptive means available to protect oneself from the unwanted pregnancy. Furthermore. with regard to the second risk, one can reply that non-abstention from sexual life is the source of the risk and not the state's prohibition. Finally, it will not always be possible to determine in the definite way whether the emotional or psychological problems result directly and exclusively from the lack of contraceptive means. Such diagnosis is usually the question of speculations, which can be questioned when trying to make a legal argument.

Furthermore, despite the Economic Committee's purportedly wide conception of "health", and its suggestion, which could be interpreted as meaning that the right to health would include the right to have access to sterilisation as a contraceptive method, its views that explicitly

\footnotetext{
${ }^{147}$ GC 14, supra note 140 para. 34.

${ }^{148}$ GR 24, supra note 146, para. 14.
} 
refer to the kinds of state actions that constitute violations of the right to health seem much more narrow:

Violations of the obligation to respect are those state actions, policies or laws that contravene the standards set out in article 12 of the Covenant and are likely to result in bodily harm, unnecessary morbidity and preventable mortality. ${ }^{1+9}$

This formulation suggests that, as far as the enforcement of the law is concerned, only in the case of those state actions that result in an immediate, physical harm to heaith the ciaim of the states violation of the right to health could be successful.

Still, with respect to certain immediate health risks, the Polish law authorises the performance of legal, therapeutic sterilisation. These include cases where pregnancy is an immediate threat to woman's physical health or life, and all efforts need to be made to prevent pregnancy, including the employment of therapeutic sterilisation. If the law prohibited this category of sterilisation. it would clearly amount to the violation of the right of health.

Also, the claim concerning the immediate health risks of being forced to use other. legal contraceptive methods, could fall into category of enforceable risks. However, again, one could argue that it is non-abstention from these methods or from sexual life, which is the source of risk and not the state. It can be also argued that treating the exposure to those risks as a violation of the right to health could justify prohibiting those methods as well.

The fact that not all aspects of the right to health are legally enforceable has been indicated in GC 14 in paragraph 1: "the right to health includes certain components, which are legally enforceable" 150 One of those elements pointed out by the Committee is "the principle of non-discrimination in relations to health facilities, goods, and services." This is supported specifically with regard to sex discrimination by Art. 12(1) of the Women's Convention, which provides for the obligation to ensure, "on the basis of equality of men and women, access to health care services, including those related to family planning". ${ }^{51}$

\footnotetext{
${ }^{149}$ GC 14, supra note 140 , para. 50. [emphasis added]

${ }^{150}$ Ibid. para. 1 [emphasis added].

ist Women's Convention, supra note 137, Art. 12(1).
} 
Nevertheless, as Brigit Toebes notes, "states cannot be expected to ensure access to all [family planning methods]." 52 The right to health under Art.12(1) could be invoked if the state allowed, for example, a man, but not a woman to undergo sterilisation, or if it required the spousal approval of the decision to undergo this operation only from women but not men. ${ }^{153}$

Finally, the Economic Committee in one of its concluding observations, commenting on the restrictive aburtion law in Cyprus, stated that "the legality of abortion is a mattcr of civil and political rights, [only] the circumstances under which such operations are performed fall within the purview of the Committee [under the right to health]." ${ }^{54}$ This can support the view that the question of delegalising or legalising of the specific method is not the issue that would be considered as enforceable under the right to health.

\section{Polish Provisions on the Right to Health}

The last remarks will concern the provision of the right to health in the Polish legal system. Art. 68 of the Polish Constitution reads as follows:

1. Everybody has the right to the protection of health.

2. All citizens, irrespective of their financial situation. must be provided by public authorities with the equal access to health services, funded from the public resources...

3. Public authorities are obliged to ensure special health protection to children, pregnant women. people with disabilities and elderly people.... ${ }^{155}$

Although paragraph one introduces a general clause of the right to protection of health, it does not seem feasible to interpret it as allowing to claim access to sterilisation under this provision, due to the following reasons. First - this general clause seems to be only an umbrella statement, which is made more specific in the following paragraphs. Paragraph two and three guarantee, similarly to the international law, the right to non-discrimination in the provision of

\footnotetext{
152 Toebes, supra note 135 at 302. The author also notes that Art. 12(2) has a different character than Art. 12(1) and it actually requires from the state to provide concrete services which are mentioned in this provison, such as: prenatal and post-natal care to women.

${ }^{153}$ This has been also indicated in the General Comment 28 of the Human Rights Committee, General Comment 28, Equality of Rights Berween Men and Women (article 3):. 29/03/2000. CCPR/C/21/Rev.I/Add IO, online: UN High Commissioner on HR Webpage, supra note 140, para. 3 [hereinafter. GC 28].

${ }^{154} \mathrm{Mr}$ Simma with regard to Cyprus, UN Doc. E/C.12/1990/SR.5, para.2 cited in Toebes, supra note 135 at 130.

${ }^{\text {iss }}$ Constitution, supra note 120, Art. 68.
} 
health services, ${ }^{156}$ and the specific obligation to actually provide certain services to particular groups, including pregnant women. ${ }^{157}$ Furthermore, the existing jurisprudence of the Constitutional Tribunal demonstrates that this right is not treated as wider than its equivalent in international law. ${ }^{138}$

\section{Conclusion on the Right to Health}

We can conclude that there is an increased support of the wide conception of health in international law. Such concept encompass, besides immediate, physical health and treatment of disease, such elements as psychological and social well-being as well as sexual and reproductive health. However, as far as the enforcement of such elements is concerned. the system seems to have some weaknesses. One of the reasons for such situation is that there are not many cases where judicial bodies held the right to health to be violated by the state in categorical terms. It seems that in the existing jurisprudence of the Economic Committee there is yet not enough support to make the argument that the non-physical harms imposed by the anti-sterilisation law in Poland amount to a violation of the right to health under the Economic Covenant or Women's Convention. However, the state should be held politically accountable for the harms, since the commitment to address them has been made by signing to the Economic Covenant as well as to the Women's Convention, the Cairo Programme and the Beijing Platform. Aart Hendriks, when discussing difficulties with enforcement of the right to health and, in particular, the right to reproductive health argues:

Until the mechanisms for supervising and enforcing implementation of social human rights are strengthened, the answer appears to be that many aspects ... related to sexual and reproductive health, are probably better protected indirectly, through enforcement of related classical human rights, than by way of reliance on the right to health itself. ${ }^{159}$

\footnotetext{
${ }^{156}$ This would accord with the requirement established by Art.12(1) of the Women's Convention, supra note 137.

${ }^{157}$ This would accord with the requirement established by Art. 12(2) of the Women's Convention, ibid.

${ }^{158}$ See e.g. Judgment of the Polish Supreme Court of 15 July 1998, (II) UKN 131/98, WOKANDA 1999/3 at 23. (question of non-discrimination in access to public funding for health services). See also: Judgment of the Constitutional Tribunal of 23 March 1999, K 2/98, OSG 1999/l 1-12 poz. 130 (involving potential physical, immediate health harms).

${ }^{159}$ A. Hendriks, "The Close Connection Between Classical Rights and The Right to Health, with Special Reference to the Right to Sexual and Reproductive Health" (1999) 18 Medicine \& Law 225 at 234 [emphasis in original].
} 
Hendriks suggests that such strategy, basing the claims on classical rights, which have a stronger grounding and position in most societies, could be more effective in "holding a state accountable" 160 for those harms that fall within the scope of the concept of health, but might meet with difficulties in their legal enforcement under the provisions of international law that guarantee the right to health. In the next section I will turn to two of these classical rights, that could morc cffectivcly protect access to sterilisation - the right to respect for private and family life and the right to equality.

${ }^{100} \mathrm{Ibid}$. at 235. 


\section{PART C. The Right to "Respect for Private and Family Life"}

\section{Introduction}

As it was noted in the introduction to this chapter, in this part I want to discuss those harms of the criminalisation of sterilisation, which impinge on the liberty interests of individuals. This category of interests, in the opinion of Wilson J.,(minority opinion) was violated in the case of Morgentaler ${ }^{161}$, decided in 1988 by the Supreme Court of Canada. in addition to the right to security of a person. which was found to be violated by the majority of the Court. Both rights the right to liberty and the right to security of a person are guaranteed in section 7 of the Canadian Charter of Human Rights. ${ }^{102}$ The case concerned restrictive abortion law, allowing a woman to have abortion only if there was a threat to her life or health. In the majority opinion. the right to security of a person was violated because the law interfered with physical integrity of a woman and imposed severe mental distress on her. In addition to that. as Wilson J. argued. "the right to liberty guaranteed by s.7 of the Charter gives a woman the right to decide for herself whether or not to terminate her pregnancy." ${ }^{.63}$ Wilson J. based her reasoning on the following arguments:

[A]n aspect of the respect for human dignity on which the Charter is founded is the right to make fundamental personal decisions without interference from the state. This right is a critical component of the right to liberty....In my view, this right, properly constructed, grants the individual a degree of autonomy in making decisions of fundamental personal importance. ${ }^{10 t}$

In support of this view, she invoked the decision of the U.S. Supreme Court in Eisenstadt v. Baird ${ }^{165}$, where the Court stated:

If the right of privacy means anything, it is the right of the individual ... to be free from unwanted governmental intrusion into matters so fundamentally affecting a person as the decision whether to bear or to beget a child. ${ }^{106}$

\footnotetext{
${ }^{161}$ R v. Morgentaler. (1988), 44 D.L. R. (4 $\left.{ }^{\text {th }}\right) 385$ (SCC).

${ }^{162}$ Canadian Charter of Rights and Freedoms, s. 7., Part [ of the Constitution Act, 1982, being scheduled B to the Canada Act 1982 (U.K.), 1982, c. Il [hereinafter: Charter].

${ }^{163}$ Morgentaler, supra note 161 at 491 .

104 Ibid. at 486.

${ }^{165}$ Eisenstadt v. Baird, 405 U.S. 438 (1972).

${ }^{160} \mathrm{Ibid}$ at p. 453 cited in Morgentaler. supra note 161. at 488.
} 
Furthermore, Wilson J., also referred to the decision in the U.S. case Roe v. Wade, ${ }^{167}$ where the U.S. Supreme Court held that the right to privacy guarantees protection from the state interference with such fundamental personal decisions as: education, child-rearing, procreation, marriage and contraception. ${ }^{168}$ Wilson J. concluded by asking whether "the decision of a woman to terminate her pregnancy falls within this class of protected decisions $" 169$ and answered it in the pusitive arguing: "[t]his decision is one that will have profound psychological, economic and social consequences for the pregnant woman." 170

In short. Wilson J. claimed that there is a certain sphere of people's lives, the sphere of fundamental personal decisions, which is protected from the interference of a state. This sphere. according to Wilson J., is protected by the right to liberty in the Canadian law. In the U.S. the courts have developed the concept of the right to privacy. although not explicitly provided by the Constitution, but based on a penumbras of rights guaranteed in the Constitution, which gives protection to liberty interests. In the international law, such sphere is protected by the right to respect for private and family life ${ }^{171}$ embraced in Article 8 of the European Convention ${ }^{172}$ and. on the universal level - in Art. 17 of the Political Covenant. ${ }^{173}$ which have been both inspired by Article 12 of the Universal Declaration of Human Rights (UDHR):

No one shall be subjected to the arbitrary interference with his privacy, family. home or correspondence, nor to attacks upon his honour and reputation. Everyone has the right to the protection of the law against such interference or attacks. ${ }^{174}$

\footnotetext{
${ }^{107}$ Roe v. Wade, 410 U.S. 113 (1973). The applicants in the case: Roe - a pregnant single woman. Does - a childless married couple and Hallford - a licensed physician, who had two state abortion prosecutions pending against him, all complained about the Texas criminal abortion laws as vague, overbroad and restricting their privacy rights. Although the American Constitution does not explicitly mention the right to privacy, the court held that, in the line of previous cases it has recognised the sphere of protected personal privacy, in which fundamental personal rights belong and that this right has extension to activities relating to marriage, procreation, relationships and child rearing or education. The Court also found that this right is not absolute, but qualified by compelling state interests in protecting health, potential life and maintaining medical standards.

${ }_{168}$ Morgentaler, supra note 161 at $\$ 89$ [emphasis added].

${ }^{169}$ lbid. at 490.

170 Ibid.

${ }^{171}$ R.J. Cook “International Protection of Women’s Reproductive Rights" (1992) 24 N. Y. U. J. Int'l L. \& Pol. 645 at 703 [hereinafter: "International Protection"].

ir: European Convention, supra note 131, Art.8.

is Political Covenant, supra note 127, Art.17.

${ }^{174}$ Universal Declaration of Human Rights, GA Res. 217(III), UN GAOR, $3^{\text {rd }}$ Sess., Supp. No. 13, UN Doc. A/810 (1948) 71 , Art. 12.
} 
The formula "right to respect for private life", and, even more so, "the right to privacy", might be confusing because of its association with the right of people to hold certain information or knowledge secret, in the concealment from public authorities or third parties (this can pertain both to, for instance, criminal proceedings, as well as, to everyday life - e.g. personal data prolection). This stands for "the privacy with its rather narrow connotations of the secrecy of information or seclusion." ${ }^{175}$ However. Art. 8 of the European Convention and Art. 17 of the Political Covenant have been given, in the international law, a much wider interpretation. and can encompass interests discussed by Wilson J. in Morgentaler - the right to have autonomy in a certain sphere of fundamental personal choices, protected from the interference of the state.

As described by Jed Rubenfeld, the sphere of "privacy" delineates a certain sphere of the individual's life within which, the individual is free to undertake certain activities. make choices and decisions, without interference of state, such as "proscription or penalty. ${ }^{-176}$ However, the most important dilemma, pointed out by both Wilson J. in Morgentaler and Rubenfed is "which choices and decisions are protected"177 from the state's interference. The question to resolve in this section is whether the ability to undergo sterilisation can be said to belong to this. protected by the law. sphere.

I will base my reasoning in this section mostly on the decisions of the European Commission and the European Court, ${ }^{178}$ the bodies that have been established by virtue of Article 19 of the European Convention "[t]o ensure the observance of the engagements undertaken by the High Contracting Parties in the Convention." 179 I will also refer to the scholarly writing

\footnotetext{
${ }^{175}$ D. J. Harris, M. O'Boyle \& C. Warbrick, Law of the European Convention on Human Rights (London: Butterworths, 1995) at 303.

176 J. Rubenfeld "The Right to Privacy" (1989) 102 Harv. L. Rev. 737 at 741 . Ibid. at 751 . Rubenfeld discusses the scope of the right to privacy with regard to the American Constitution. Nevertheless, as far as the legal concept and not specifically limits of this right is concerned, his reasoning can be relevant also for the international order.

17 lbid. at 751 .

i7 Protocol 11 to the European Convention, which came into force on 1 November 1998 has changed the structure of the supervisory organs of the Convention. The European Commission ceased to exist and the Court itself took over the functions previously performed by the Commission. However, there is the vast body of the Commission's "jurisprudence" that has been developed during the years of its work, included in it, the Commission's decisions on admissibility of applications, decisions on merits or reports prepared for the Court's proceedings.

${ }^{179}$ European Convention, supra note 131 Art.19.
} 
developed with regard to this body of jurisprudence. There are several reasons that contributed to the thorough review of these materials.

First of all, the European Convention's organs' jurisprudence under Article 8 (alike under other provisions) is very extensive ${ }^{180}$ and diverse. Secondly, the decisions of the European organs are characteristic for their well-developed reasoning. Conclusions concerning admissibility of the application or determining whether the alleged violation of law took place are supplemented by in-depth reasoning. Furthermore, the jurisprudence of the European Commission and Court plays a vital role and contributes to the "normative development of other parts of the international human rights system."181 Finally, the European human rights system. developed under the European Convention is considered to have the most effective enforcement mechanisms. $^{182}$

Where applicable and available. I will be also taking into account the views of the HRC with regard to Article 17 of the Political Covenant.

The right to respect for private or family life?

Article 8 of the European Convention mentions, in fact, four different concepts: the right to respect for private life, the right to respect for family life, the right to respect for home and the right to respect for correspondence. The two last elements are not relevant for this work. However, the question to be answered under this heading is whether I want to argue that the criminalisation of sterilisation is the violation of the right to respect for private or for family life. In the previous chapter I have pointed to the fact that the lack of access to sterilisation can have harmful effects on both individuals and relationships, due to the interference with sexual life and well-being, and, for this reason - both individual and family aspects should be considered respectively.

${ }^{180}$ See e.g. H.J. Steiner \& P. Alston, International Human Rights in Context: Law, Politics, Morals (Oxford: Clarendon Press, 1996) at 571.

181 Ibid. at 598.

${ }^{182}$ See e.g. L.R. Helfer "Consensus, Coherence and the European Convention on Human Rights" (1993) 26 Cornell Int'l L.J. 133 at 133. 
The claim to be explored in this section is the claim that the anti-sterilisation law in Poland violates an individual's right to respect for private and/or family life guaranteed in Art.8 of the European Convention and Art. 17 of the Political Covenant.

\section{The Harm}

We should start from recapitulating briefly arguments from the previous chapter, the part concerning harms of anti-sterilisation law in Poland. I argued that sexual intimacy is an important aspect of the life of an individual and a spousal or permanent relationship. With regard to an individual. sexual expression is part of one's sexual identity; it is means to express one's affection, admiration for another person, it is important for one's self-confidence and general well-being. The interference with sexual intimacy may result in low self-esteem and distress. For a couple, sexual intimacy is a mean to build emotional intimacy. it allows for the expression of commitment, fidelity. Sexual life is closely linked to the satisfaction from a relationship. it affirms commitment and enhances relationship. A disruption of sexual life may lead to the disruption of harmony in the relationship and to the weakening of the bond between a couple.

Such disruption, interference with sexual intimacy may result, as I have discussed in the previous chapter, from the lack of comprehensiveness of contraceptive options. Besides the interference with sexual intimacy, the lack of comprehensive contraceptive options may also result in enforced parenting, which, as I have implied earlier, may have negative effects on the well-being of a relationship by putting more restraints on the couple's time and resources. This may be harmful for the social, intellectual and emotional development of children, because parents might have less time and not be able to pay as much attention to the care of children as necessary. Enforced parenting can be also harmful for the bond between a couple, since they will have less time for couple-oriented activities. Anti-sterilisation law, in general, can interfere with the well-being of all members of the family and the family as a whole. 


\section{Response of International Law}

\section{Does decision about sterilisation belong to the sphere protected by Art. 8 ?}

The European Commission of Human Rights in the case of Brïggeman and Scheuten $v$. Federal Republic of Germany ${ }^{183}$ considered harms, similar to the ones described above. In Brïgyemun, two German women claimed violation of Article 3 of the European Convention. which, in their view, resulted from provisions of German law restricting access to abortion ${ }^{184}$ and forcing them to either renounce sexual life or use contraceptive methods that they have disapproved of or to carry unwanted pregnancy to term. ${ }^{185}$ The Commission had to examine whether this amounted to the interference with the right to respect for private life. The Commission has resolved this question in negative. Since this decision discusses a lot of similar issues to the case of anti-sterilisation law, the reasoning of the Commission in this case requires careful consideration.

First, the Commission's conclusion on merits in Brüggeman (Brüggeman II) was based on the finding that "pregnancy cannot be said to pertain uniquely to the sphere of private life."186 This was in a striking contrast to the decision made in the admissibility proceedings in this case (Brüggeman $I$ ), in which it was concluded that "pregnancy and the interruption of pregnancy are

\footnotetext{
${ }^{183}$ Brügemann and Scheuten v. Federal Republic of Germany (1977), App. No. 6959/75, Commission's decision on admissibility of 19 May 1976, 5 Eur. Comm. H.R. D. R. (D\& R) 103 [hereinafter: Brügemann I]. Commission's decision on merits 3 E.H.R.R. 244 [hereinafter: Brigemann II].

14-Prior to 1974, German Criminal Code made an abortion punishable except if indicated on medical grounds. In 1974 Bundestag introduced a liberal amendment - the Fifth Criminal Law Reform Act, which would allow abortion up to 12 weeks after conception without any particular indications. The only requirement for a woman was to undergo consultation and receive medical counselling. In 1975 the Federal Constitutional Court first suspended the proposed legislation before it came into force and later decided that the amendment was incompatible with the Basic Law (German Constitution) and rendered it void. The Court reasoned that the Act "does not comply in sufficient degree with the constitutional obligation to protect the unborn child". Subsequently the Bundestag in 1976 enacted the Fifteenth Criminal Law Amendment Act. This law was more liberal than prior to 1974 in respect of permitting abortion if "in view of her present and future living conditions the termination of the pregnancy is advisable according to medical knowledge in order to avert a danger to her life or the danger of a serious prejudice to her physical or mental health ..." However, it was possible for a court to abstain from punishment if a woman was in a particular distress. (Facts regarding legislation summarised after the European Human Rights Reports, Brügemann II, ibid. para. 15-25 at 245-251).

185 Ibid. para. 50 at 251.

${ }^{186}$ Ibid. para. 59 at 253.
} 
part of private life, and also, in certain circumstances, of family life""\$87 and that "legal regulation of abortion is an intervention in private life which may or may not be justified under Article 8(2)." 188 The latter was based on two important principles developed in earlier jurisprudence of the European Commission. First of them was:

[C]oncept of private life in Art.8 comprises also, to a certain degree, the right to establish and to develop relationships with other human beings. especially in the emotional field for the development and rutrïiment of one's own personaiity. ${ }^{100}$

Second, in the case of $X v$. Federal Republic of Germany, ${ }^{190}$ it was noted by the Commission: "[a] person's sexual life is undoubtedly part of his private life of which it constitutes an important aspect."

It is important to note that cases. starting from $X$ v.FRG. ${ }^{192}$ in which the principle that sexual life is an important aspect of private life meriting protection of Art. 8 has been developed and reaffirmed, concern complaints with regard to the legislation punishing homosexual relations. This fact might have contributed to the situation where this sphere - the sphere of sexual life - has not been pronounced as also meriting protection under the clause of respect for family life. This can be illustrated by the case of $X \& Y v$. United Kingdom. ${ }^{193}$ In this case applicants: a Malaysian citizen and U.K. citizen had a stable homosexual relationship and complained about immigration rules which did not allow them to stay together legally in the U.K. They brought their complaint under not only the provision of the right to respect for private life, but also the right to respect for family life. However, the Commission announced:

\footnotetext{
${ }^{187}$ Brügemann l, supra note 183 at 115.

188 Ibid.

${ }^{189}$ Xv. Iceland (1976), App. No. 6825/74, 5 Eur. Comm. H.R. D. R. (D \& R) 86. The applicant complained about not being able to keep a dog in the city of Reykjavik. The Commission held the application inadmissible and stated that Art. 8 of the European Convention does not protect the right to keep a dog.

${ }^{190} X$ v. Federal Republic of Germany (1975), App. 5935/72, 3 Eur. Comm. H.R. D. R. (D \& R) 46. The applicant complained of a conviction for the commitment of indecent acts with minors of the same sex. The Commission held that although "sexual life is undoubtedly part of his private life of which it constitutes an important aspect", "[t]he fact remains that the action of the German legislation was clearly inspired by the need to protect the rights of children and adolescents and enable them to achieve true autonomy in sexual matters." [hereinafter. $X v$. FRG]. 191 lbid.at 54.

${ }^{192} X v$. FRG, supra note 190.

${ }^{199} X \& Y$ v. United Kingdom (1983), App. No. 9369/81, 32 Eur. Comm. H.R. D. R. (D \& R) 220.
} 
Despite the modern evolution of attitudes towards homosexuality, the Commission finds that applicant's relationship does not fall within the scope of the right to respect for family life ensured by Art. $8 .^{194}$

This ruling has been interpreted as the Commission's unwillingness to broaden the concept of family to encompass relationships between homosexuals. ${ }^{195}$ Such limitation, however, should not have a bearing onto the question of whether, in general, sexual life should be considered as part of family life. After all, sexual life is an important aspect of family life and has a bearing on the quality of life of a family.

The resolution of this matter - whether sexual life and interests associated with it merit protection under the right to respect for family life - would be facilitated if the Commission in Brïggeman I indicated how it understood the "certain circumstances" in which the regulation of abortion could be considered as interference with family life. We can presume, however, that one of such circumstances could be the family situation of people concerned. If their life as a family, and not only as individuals. could be influenced by the decision on abortion. then we could talk about the interference with family life. If this is the case, then the decision about sterilisation. when considered in the context of a married couple with several children. should be considered as pertaining to the protected sphere of family life. since family can be greatly influenced by a birth of another child - making the family's financial situation more difficult and putting more pressures onto the parenting capabilities of a couple.

We should now return to the reasoning, which allowed the European Commission in Brïggeman II to conclude that the termination of pregnancy did not belong to the private sphere protected by Art. 8, despite the principle developed in its earlier jurisprudence that sexual life forms an important part of private life. In justifying its decision, the Commission referred to case of $X$ v. Iceland" 196 in which it stated that whenever a particular behaviour is "necessarily

\footnotetext{
194 lbid. at 221.

${ }^{195}$ See e.g. J. Cooper, "The Last Taboo - Establishing a Right to Sexual Identity" (1995) 9(4) Interrights Bulletin 107 at 108.

$196 \mathrm{Xv}$. Iceland, supra note 189 . In fact, the decision of the Commission that the right to keep a dog is not protected by the right to respect for private life was based on two findings. First, that the right to private life comprises of the right to develop relationships with other human beings - but not with the entire immediate surroundings - not with animals. Only subsidiary did the Commission remarked on the fact that the keeping of the dog "by the very nature
} 
associated with certain interference with the life of others...", it does not come within the scope of private life. In the opinion of the Commission, when a woman is pregnant, her behaviour, including the decision to terminate pregnancy is "closely connected with the developing foetus" 197 and its interests. Hence, the decision transcends the private sphere. There are certain aspects of this decision that indicate that its conclusion as to the scope of private sphere should not be, at present, determinative for the exclusion of the right to sterilisation from the private sphere protected by Article 8 of the European Convention.

The Commission claimed that the decision that abortion does not come within a scope of private life allowed it to avoid a comparison and weighing of interests of a woman and a foetus. as well as, to avoid deciding on the issue of the foetus's right to life. ${ }^{198}$ As a matter of fact. it could be argued that the Commission took into account interests of the foetus as if it was another entity, whose rights were intrinsically involved in any decision concerning the woman's body during the pregnancy and whose rights had to be protected by the state. The distinction between an intervention of a state in a decision, which is not considered a private matter. because it necessarily touches upon interests of another entity and an intervention in a decision, which is considered a private matter, but which does not constitute an unlawful interference, because it involves interests of another party - is not clear enough. It also results in the same conclusion as to the legal implications of the intervention. It would be more straightforward and probably more convincing for the Commission to frame it in terms of article 8(2), as Commissioner Fawcett suggested in his dissenting opinion. ${ }^{199}$ In conclusion, the final decision of the Commission to exclude the decision to terminate pregnancy from the sphere of private life was based on the fact of existence of state interest in protecting certain rights of a foetus.

As far as sterilisation is concerned, the decision about sterilisation may have important influence on persons other than a person undergoing it, especially one's sexual partner, thus, we can talk about certain interests of a partner in the other partner's ability to procreate. However,

of that animal [is] necessarily associated with certain interferences with the life of others and even with the public life."

${ }^{197}$ Brüggeman II, supra note 183, para. 59 at 253.

${ }^{198}$ lbid. para. 60 at 253. 
these interests, according to the principles developed in the jurisprudence of international bodies, cannot infringe on the person's right to make decisions in the sphere of procreation. Thus, we can't talk about the existence of the state interests intrinsically involved in protecting the partner's right to the other partner's ability to procreate. In this regard, we should revoke the principle that access to contraceptives and abortion (if legal) can not be conditioned on the partner's approval. ${ }^{2 m}$ This principle has been affirmed by the European organs, for instance, in the case of Paton v. United Kingdom ${ }^{201}$, where the European Court rejected the application of a potential father claiming to be a victim of violation of the right to life of a foetus as well as his own right to respect for family life, because he did not have to be consulted and was not able to veto a woman's decision on abortion. This principle supports the view that the case of antisterilisation law can be distinguished from the case of Brüggeman because the former does not. in an inherent way, involve the rights of other entities. And as such. the decision about sterilisation, which has bearing on the sexual life of a person and on her ability to develop relationships should be considered as belonging to the sphere of private life.

This point, was. in fact, admitted by the government of Germany in Brïggeman II. which. while protesting against the notion of including decision about abortion into the sphere of private life, has, at the same time stated the following:

There are no objections to the assumption that the arrangement of the sexual relations as well as family planning, come on principle, within the sphere of private and family life protected by art. 8(1).

Finally, the view that decision about abortion, and, thus, even more so, the decision about sterilisation, should be considered as belonging to the protected private sphere was also expressed in Brüggeman II by the minority of three judges: Opsahl, Nørgard and Kellberg. Opsahl J., writing for minority, stated that the decision of a woman to terminate pregnancy in its

\footnotetext{
${ }^{199}$ lbid, Dissenting Opinion (Mr. J. E. S. Fawcett) para. 1-7at 255.

$=00$ See e.g. GC 28, supra note 153 (HRC on equality) para. 20: "Another area where States may fail to respect women's privacy relates to their reproductive functions, for example, where there is a requirement for the husband's authorization to make a decision in regard to sterilization ..."

${ }^{201}$ Paton v. United Kingdom (1980), App. No. 8416/78, 3 E..H.R.R. 408. See also R. J. Cook \& J. M. Haws, "The United Nations Convention on the Rights of Women: Opportunities for Family Planning Providers" (1986) 12:2 Int'l Family Planning Perspectives 49 at 50. See also "International Protection", supra note 171 at 697.
} 
early stage "is the most consistent with what we think a right to respect for private life in this context ought to mean in our time."202

The arguments invoked above give strong support for the opinion that decision to undergo sterilisation belongs to the sphere of private life, protected by Art. 8 . The conclusion that it also pertains to the second sphere safeguarded by Art.8 - the sphere of family life - should follow from the fact that harms of anti-sterilisation !aw influence in a fundamental way not only the lives of individuals treated separately, but also the well-being of a family as a whole. Two aspects of the well-being of family were pointed in the section concerning harms: first. the importance of sexual intimacy for the enhancement and durability of a bond between a couple. and second - the importance of the ability to control the size of the family. which allows to ensure its financial security and enables more time for parenting responsibilities to existing children, to ensure their best emotional, intellectual and social development. This seems to have been acknowledged by the Commission in Brïggeman 1. 203 It seems that it is only the legacy of the European organs" unwillingness to name a homosexual relationship "a family" that have contributed to leaving out the "family" part with regard to the importance of protection of sexual life and interests related to it. It was not the fact that these kinds of harms should. in principle, be excluded from falling within the protected sphere of "family life".

Can the anti-sterilisation law constitute interference with the right to respect for private life?

The determination that certain decision belongs to the sphere of private or family life is not sufficient for the conclusion that state interference with this decision would amount to the interference with the right to respect for private or family life. This was emphasised by Opsahl in Brüggeman II, who stated that many legislative decisions have some influence on private or

202 Brügemann II, supra note 183, Separate Opinion (Mr. T. Opsahl) at 258. Opsahl, however, immediately after this statement, makes a reservation that the Convention might not prohibit the state to interfere into this decision, but that this should be based on a different reasoning than that provided by the majority decision. This aspect will be discussed below.

${ }^{203}$ Supra note 187 and accompanying text. 
family life, but they might not "represent interference with the right to respect for private [and family] life." $20+$

In this section, I will only consider this question with regard to the first sphere - the sphere of private life. This separate consideration is justified by the fact that cases relating to "family life" bring into play a different set of concerns, which need to be examined individually.

Opsahl in Brüggeman II argued that the impugned German abortion legislation did interfere with private life. but that it still gave respect for this sphere. In my view, such conclusion was possible, because the impugned legislation maintained the option of abstaining from punishment for the performance of abortion in the situation of a risk of serious distress of a woman. This option, as remarked in the proceedings before the Commission, was interpreted in practice rather liberally. ${ }^{205}$ As a result, the situation with regard to access to abortion in Germany was less restrictive than in many other countries of the Council of Europe. This is another feature of Brïggeman, by which we can distinguish it from the case of Polish anti-sterilisation legislation. Anti-sterilisation law in Poland is highly restrictive as compared to the situation in the majority of European countries. ${ }^{206}$ Other European countries may not provide with an unlimited access to sterilisation, but may sometimes stipulate certain restrictions concerning age limit or a number of children that a person wishing to undergo sterilisation operation must have. Restrictions like that can be seen as measures to secure that the decision about sterilisation is made in the fully informed and competent way. ${ }^{207}$ These kinds of regulations of access to sterilisation, as compared to the complete ban on it, could, supposedly, be considered as an example of interference with private (or family) life which would not amount to the lack of respect for it. On the other hand, Polish anti-sterilisation law is an example of a highly restrictive regulation, and as such, should be considered as having no respect for the private sphere.

\footnotetext{
204 Ibid. [emphasis in original].

205 Brügemann II. supra note 183, para. 65 at 255.

${ }^{200}$ This aspect will be discussed in more detail in Chapter IV, part B, below in the context of the evolving "European Consensus" concerning accessibility of sterilisation as a contraceptive option.

${ }^{207}$ This aspect will be discussed in Chapter IV, part C, below.
} 
Can the anti-sterilisation law constitute interference with the right to respect for family life?

Even though sterilisation decision can be said to pertain to the sphere of family life protected by Art.8, the establishment that the Polish anti-sterilisation law amounts to the interference with the right to respect for family life, in the view of existing jurisprudence relating to family life might be more difficult to advance than with regard to private life.

In the case of Marckx $v$. Belgium, ${ }^{208}$ the European Court established the principle that the right to respect for family life requires from the state to act in such a way as to allow family ties and family life to develop normally. ${ }^{209}$ In the cases following Marckx, various actions or inaction of the state have been considered as either infringing on the normal development of family life or as required from the state to fulfil its positive obligation towards guaranteeing such development. ${ }^{210}$

The majority of cases relating to family life concerned matters of immigration or deportation, child custody, access to children, or else, the ability to create a legal tie between children and their biological or social parents. An example from this category is the case of Eriksson v. Sweden. ${ }^{211}$ where Mrs. Eriksson complained about the decision to remove her child to a foster home for an indefinite period of time and about limitations imposed on her access to the child. The European Court in this case established the principle that " $[t]$ he mutual enjoyment by parent and child of each other's company constitutes a fundamental element of family life."12 The characteristic feature of this case and the majority of cases in this category is that they

\footnotetext{
${ }^{208}$ Marckx v. Belgium (1979), 31 Eur. Ct. H. R. (Ser. A), 2 E.H.R.R. 330.

209 Ibid. para. 45 at 348.

310 It was already in the Marckx case that the Court established that art. 8 "not merely compel the State to abstain from ....interference: in addition to this primarily negative undertaking, there may be positive obligations inherent in an effective 'respect' for family life.", ibid. para. 31 at 342. It was then reaftirmed in the case of Airey $v$. Ireland, (1979), 32 Eur. Ct. H. R. (Ser. A), 2 E.H.R.R. 305, para. 32 at 319 (The applicant, a married Irish woman complained about the ineffectiveness of the right to respect for family life, because of her inability - due to lack of financial resources for getting a lawyer - to apply for a judicial separation, and thus, for the effectively accessible right of a determination of rights and obligations created by Irish family law).

311 Eriksson v. Sweden, (1989) App. No. 11375/85, 156 Eur. Ct H. R. (Ser. A), 12 E.H.R.R. 183.

212 Ibid. para. 58 at 200.
} 
concern the most drastic measures - limitations or inability to meet on regular basis, ${ }^{213}$ to live together or to live in one country. ${ }^{214}$ All these cases concerned the minimum requirement for the "normal family life" - the requirement of being able to be together. They did not concern more substantive matters that influence the life of the family - such as, for instance, financial or social support for the family, while this is the category of concerns, which is at stake with regard to anti-sterilisation law. In this case, it is not the question of bcing able to be together but the question of quality of family life, the well-being of a family.

There are a few cases that have, to some extent, discussed the state is involvement (by either interference of abstention) in the sphere of "substance of family life." ${ }^{215}$ I will invoke, in this respect. three cases: the Belgian Linguistics ${ }^{216}$ case, the already mentioned Marckx ${ }^{317}$ case. and, finally, the case of $X . Y \& Z v$. United Kingdom. ${ }^{218}$

In Belgian Linguistics, a group of French-speaking parents claimed, among other things. that the government, under the right to respect for their family life. is obliged to fund education of their children in French-speaking schools. The Court stated that Art. 8 did not guarantee the right to be educated in the language of one's parents by the public authorities or with their aid. The Court emphasised that Art. 8 mainly concerned negative obligation of the state to abstain from the interference with lives of individuals. It did, however, at the same time, remarked that certain matters regulated by rules pertaining to education system could fall within the scope of protection afforded by Art. 8. Such protection could relate to measures such as that their "aim or result were to disturb private or family life", for example, separating children from their parents

\footnotetext{
${ }^{213}$ See also Olsson v. Sweden (1988) App. No. 10465/83, 130 Eur. Ct. H. R. (Ser. A), I I E.H.R.R. 259. In this case the fact that children were placed in foster homes in the great distance from parents' home and from each other and that restrictions on the parents' visits were imposed was found to be the violation of the right to respect for family life.

214 See e.g. Berrehab v. The Netherlands (1988), App. No. 10730/84, 138 Eur. Ct. H. R. (Ser. A), II E.H.R.R. 322. The case concerned a father who was refused a residence permit in the Netherlands, which inhibited him from maintaining regular contact with his daughter. The Court found it to be the violation of the right to respect for family life.

${ }^{215}$ The term used in Harris, O'Boyle \& Warbrick, supra note 175 at 331.

${ }^{216}$ Belgian Linguistics Case (No. 2) (Case Relating to Certain Aspects of the Laws on the Use of Languages in Education in Belgium) (1968), 6 Eur. Ct. H. R. (Ser. A), I E. H. R. R 252 [hereinafter: Belgian Linguistics]. ${ }^{217}$ Marckx, supra note 208.

${ }^{218} X, Y \& Z$ v. United Kingdom (1997), App. No. 21830/93, 24 E.H.R.R. 143 [hereinafter: $X, Y \& Z v . U K$ ].
} 
in arbitrary way. ${ }^{219}$ The European Court, in this case, despite the claims of applicants, pointed only to the most drastic measures, concerning the ability to be together that could be protected by Art. 8 and not those measure which could affect the internal life of a family which is allowed to live together. An important aspect of this case is that the parents' claim concerned appropriating public funding, a requirement of positive measure from the state.

The applicant in Marckx was a mother of an illegitimate child. According to Belgian law, in order to establish legal ties with her daughter, she had to recognise the child in legal proceedings. However, this act would not put the child in a position equal to that of a legitimate child, because of, for example, the illegitimate child's limited ability to inherit mother's property. The Court decided that "the dilemma which exists at present is not consonant with 'respect' for family life because it thwarts and impedes the normal development of such life."220 It is important to note that in the majority decision of the Court the understanding of "normal family life" or "normal development of family life" was, in fact, based more on the comparison between the situation of legitimate and illegitimate children. and not so much on analysing what is actually required to lead such family life. The discussion in this direction was developed in dissenting opinions accompanying the judgment. Vilhjalmsson J., for instance, noted that Art. 8 should not be read as dealing in any way with "the financial side of the relationship." 221 Similarly Fitzmaurice J., could not agree with broadening the sphere protected by Art. 8 to matters of inheritance. He agreed that "question of inheritance can have repercussions on family life" but stated that "so can many other things." protection afforded by Art. 8. Fitzmaurice argued:

It has at no time been suggested that there has ever been any lack of respect for the family life of Marckxes if the term 'family life' is given the meaning it would normally convey (and be confined to) in the understanding of the 'man-in-the-street', namely meaning the day-to-day life of the family in the home .....

\footnotetext{
219 Belgian Linguistics, supra note 216, para. 7 at 283.

220 Marckx, supra note 208 para. 36 at 344.

221 lbid. Partly Dissenting Opinion (Judge Thor Vilhjälmsson) at 363.

m Ibid. Dissenting opinion (Judge Sir Gerald Fitzmaurice) at 370.

29 lbid.

24 lbid at 369.
} 
Of a different opinion was Matscher J., who claimed that issues of succession on death should be held as "a significant element of family life"

It is really only the dissenting opinions that point to the confusion about the issue of whether the respect for family life could require intervention or the abstention from intervention in the internal life of the family, in its substance, in the quality of its life. The majority opinion has avoided this dilemma by making a comparison to the family situation of a legitimate child. which, in its view represented "normal family life." However, were such comparison not involved, the Court would probably be less inclined to broaden the scope of what is necessary for the "respect for family life" besides those "most drastic measures." discussed in immigration or custody cases. This unwillingness can be inferred from the remarks of Vilhjalmsson and Fitzmaurice, who tried to address this issue more directly by asking - whether the obligation to respect development of the "normal family life" would require, for example. ascertaining financial security for its members. It seems that the majority in Marckr, although avoiding to give a conclusive answer to this question, as compared to the straightforward negative resolution in Belgian Linguistics, has left the question unresolved. However. Marckx opened the possibility to bring forward issues that do not pertain solely to the question of the ability to live together. Matscher. who argued in favour of the positive answer to the question of the need to protect "the substance of family life," thought it was necessary at the same time to signal the potential "threat" of such approach. This provoked him to make the following reservation:

[I]t must be emphasised that ... the positive obligation that arise under Art. 8 is limited to what is strictly needed for establishing and developing family life...."

Finally, the substantive issues have been involved in the case of $X, Y \& Z v . U . K{ }^{127}$ The case concerned a transsexual $(X)$, his female partner $(Y)$ and her child $(Z)$, who complained about the fact that $\mathrm{X}$ was not permitted to be registered as $\mathrm{Z}$ 's father. The government of United Kingdom argued that the applicants were able to live together as a family and that $\mathrm{X}$ was not

\footnotetext{
Is lbid Partly Dissenting Opinion (Judge Matscher) at 382.

${ }^{26} \mathrm{lbid}$. at 380 . [emphasis added]

${ }^{m} X, Y \& Z v$. UK, supra note 218 .
} 
restricted in playing the role of a social father for $\mathrm{Z} .{ }^{228}$ The government, thus, based its objection on the fact that there was no interference with family life in the narrow meaning, limited to the "most restrictive measures," such as those in: Eriksson, Olsson or Berrehab229. The applicants in $X . Y \& Z v . U . K$. on the other hand, pointed to two classes of consequences arising from the inability to register $X$ as a father of $Z$ : legal consequences; no inheritance rights of $Z$ in the case of $X^{\prime}$ 's intestacy and no succession to certain tenancics; as well as, social and psychological impact on Z, such as: distress arising from the lack of father's name on birth certificate or social and development difficulties which could result from undermining the sense of $Z$ 's personal identity and security within the family. ${ }^{230}$ The Court took these harms into account and considered them carefully, although it did not go as far as to regard them as amounting to the violation of the right to respect. It has justified this move by pointing to the following reasons. First of all, as far as legal consequences were concerned, these difficulties were evaluated as not resulting in an undue hardship imposed upon applicants, since the applicants were able to find a sufficiently satisfactory solution to these problems - such as, for instance, to ascertain that $Z$ is included in X's will. Furthermore, with regard to social or psychological harms. the Court stated: "[I]t is impossible to predict the extent to which the absence of legal connection between $\mathrm{X}$ and Z will affect the latter's development." 231 The Court argued also:

[A]t present time [there is among the Contracting States no generally shared approach, certainty] with regard to how the interests of children in $Z$ 's position can best be protected and [thus] the Court should not impose any single viewpoint. ${ }^{32}$

The basis for rejecting the inclusion of the harms concerning the "substance of family life", were, it seems, two-fold. First, the Court seems to must have agreed to some extent with the government claim that "the concerns expressed by [applicants] were ... theoretical." (what has also contributed to the first finding), the Court referred to the fact there has not been the European consensus developed which would, first of all, give support and confirm the

\footnotetext{
${ }^{m s}$ Ibid. at 170.

229 See supra notes $211,213,214$.

230 lbid. at 170-171.

${ }^{31}$ Ibid. para. 51 at 171.

32 Ibid.

33 Ibid. para 46 at 170 .
} 
applicants' claims as to the link between the state's restrictions and the implied harms resulting from it, and second, which would point to the uniform solution for the question of this issue in domestic legal orders of European countries.

We should view the decision in $X, Y \& Z v . U . K$ as a one step further from Marckx. The majority in $X, Y \& Z v$ v. U. $K$ expressed its willingness to discuss harms pertaining to the substance of the life of a family, especially if, as in this case, the question is not one of positive obligations - requiring from the state to provide with resources. but it is a question of abstaining from interfering with the way individuals want to shape their own lives. ${ }^{234}$ However, the Court suggested that the link between the implied harms and the state's interference would have to be supported with strong evidence. and would have to be made more clear and certain. Another obstacle to overcome was that the Court suggested it would be inclined to leave a wide margin of appreciation for the state to justify harms of this kind if there was no consistent practice with regard to the measures in question in other State Parties. ${ }^{235}$

\section{Conclusion on the Right to Respect for Private and Family Life}

I have argued in this part that the decision about sterilisation should be regarded as a fundamental personal choice belonging to the sphere of private and family life protected by Art. 8 of the European Convention and Art. 17 of the Political Covenant. The argument forwarded in support of this view was the fact that this decision may have a bearing on the ability of an individual to arrange one's sexual sphere and to control the size of a family. This decision has a bearing on one's sexual and overall well-being. Furthermore, contraceptive choice, as influencing sexual intimacy, is important for the development and enhancement of a relationship, and the well-being of a family. Finally, the ability to control a number of children allows a couple to influence the well-being of the family by having more control over its financial

\footnotetext{
${ }^{34}$ See e.g. ibid. Dissenting Opinion (Judge Foighel). at 179.

is Ibid. para. 44 at 169: "Since the issues in the case ... touch on areas where there is little common grounds amongst the Member States of the Council of Europe and, generally speaking, the law appears to be in a transitional stage, the respondent State must be afforded a wide margin of appreciation."
} 
situation and by being able to put more time and efforts into their parenting roles, crucial for the social, emotional and intellectual development of children.

The total ban on sterilisation in Polish law, being highly restrictive as compared with regulations in the majority of other European countries and as compared to the regulation of access to other contraceptive means. should be regarded as interfering with the right to respect for private lifc. Such conclusion is more difficult with regard to the right to respect for family life in view of the more stringent test established in the cases relating to family life. So far, the European Commission and Court have found that only those measures, which have been described in this section as "most drastic measures" interfering with the ability to live together as a family have been found as amounting to the lack of respect for this sphere. However. the life of the family and its well-being depends not only on the ability to live together, which obviously is the basic requirement, but also numerous other circumstances. such as financial situation. or social support, or, as I have been arguing in this work, access to the full and comprehensive choice of contraceptive means. All of them have a bearing on the "substance of family life." European organs have been called to recognise state's action or inaction pertaining to such substantive matters in several cases. As the last of them $-X, Y$ and $Z v$. U.K. demonstrates, the European organs are becoming increasingly sensitive to such issues. In the case of antisterilisation law there would be no barrier such as the lack of European consensus on this issue and it would not concern positive obligations, which the Court might be less willing to impose upon a state. For this reason, the chances of holding anti-sterilisation law to violate the right to respect for family life are even bigger than in $X, Y \& Z v$. U.K. However, $X, Y \& Z v$. U.K. puts a very stringent requirement of demonstrating with high precision and certainty that there are on other ways to avoid the harms implied. This might be a rather difficult task in the case of antisterilisation law. Furthermore, the harms of this law could be, as in $X, Y \& Z v$. U.K., held as more speculative. ${ }^{236}$ There are, nevertheless some differences. We can, for instance, point to the

\footnotetext{
${ }^{36}$ This aspect has been mentioned in the part concerning the right to health. Chapter III, Part B, above.
} 
jurisprudence of the Committee on the Elimination of Discrimination Against Women, which describes that "there is a general agreement" with regard to the occurrence of such harms. ${ }^{237}$

Nevertheless, the fact that the invocation of violation of Art. 8 with regard to family life has lesser chances of success, should not restrain us from invoking the violation of Art. 8 with respect to these two spheres taken together. The practice of the European organs demonstrates that it is not always necessary to imply the violation of only one or only the other. In some cases European organs themselves used a co-terminacy ${ }^{238}$ referring to all spheres protected by Art. 8 . Invocation, of both spheres, even if it was unsuccessful with regard to family life. which can be said to be a "qualified" category of private life. ${ }^{39}$ is important for emphasising that these are not only individualistic, personal interests involved in this matter, but also, the well-being of a family.

Limitations on the right to respect for private and family life

Article $8(2)$ of the European Convention states limitations on the right to respect for private and family live:

There shall be no interference by a public authority with the exercise of this right except such as in accordance with the law and is necessary in a democratic society in the interests of national security, public safety or the economic well-being of the country, for the prevention of disorder or crime, for the protection of health and morals, or for the protection of the rights and freedoms of others. ${ }^{2+0}$

Article 17 (1) of the Political Covenant reads: "No one shall be subjected to arbitrary or unlawful interference with his privacy"2+1! The HRC in its General Comment 16 provided states with interpretation of this Article ${ }^{2+2}$. The HRC interprets "arbitrary interference" as being "in accordance with the provisions, aims and objectives of the Covenant and reasonable in particular

\footnotetext{
${ }^{37}$ See supra note 100 and accompanying text.

${ }^{238}$ See e.g. Klass and Others v. Federal Republic of Germany (1978), 28 Eur. Ct. H. R. (Ser.A), 2. E.H.R.R. 214.

29 See e.g. G. Cohen-Jonathan, "Respect for Private and Family Life" in R. St. J. Macdonald, F. Matscher \& H. Petzold, eds., The European System for the Protection of Human Rights (Dordrecht: Martinus Nijhoff Publishers, 1993) 405 at 407.

$2+0$ European Comention, supra note 131, Art. 8(2).

241 Political Covenant, supra note 127, Art. 17(1).

${ }^{242}$ Human Rights Committee, General Comment 16. The Right 10 Respect of Privacy. Home and Correspondence, and Protection of Honour and Reputation (Article 17): 08/04/88.
} 
circumstances"243 Martin Scheinin on the basis of this Comment and case law of HRC draws a conclusion that limitations of right to privacy (Art. 17 of the Political Covenant) and right to respect for private and family life (Art. 8 of the European Convention) are comparable in scope. ${ }^{2+4}$ This has also been confirmed in the case of Toonen v. Australia, ${ }^{2+5}$ in which the HRC has extensively referred to the jurisprudence of the European Court. ${ }^{216}$ This is consistent with the general practice of the HRC to take benefits of and apply in its practice principles developed by the European Commission. Alston and Steiner write:

the [HRC] ha[s] frequently referred to judgements of European Court. Its unacknowledged and perhaps unrecognised influence may have been even greater. ${ }^{2+3}$

The reasoning of the European Commission and Court in the cases concerning violation of the right embodied in Article 8. as a result of the formulation of its second paragraph, is always broken up into certain segments. according to the "list" of the elements determinative whether the state's intervention into the sphere of privacy is justified. as provided by that paragraph. Each element of the list: the fact of an interference by a public authority (1); the issue of the proscription by law (2); and 6 permissible grounds for justification (3): national security, public safety, the economic well-being of the country. prevention of disorder or crime, the protection of health and morals, and the protection of the rights and freedoms of others; are discussed separately in the decisions of European organs. The last element of the list. the necessity in a democratic society (4), is the verification test that has to be applied against each of the proposed grounds for justification.

\section{(1) The fact of an interference by a public authority}

In the decision in Johnston v. Ireland, ${ }^{2+8}$ the European Court emphasised that it is not necessary to demonstrate existence of an actual detriment, but that the applicants claiming the

\footnotetext{
${ }^{243}$ Ibid. para. 4.

244 M. Scheinin, "Sexual Rights as Human Rights - Protected under Existing Human Rights Treaties?" (1998) 67 Nordic J. Int'l L. 17 at 30.

iss Toonen v. Australia, Communication No. 488/1992: Australia. 04/04/94. CCPR/C/50/D/488/1992

${ }^{246}$ The HRC referred to following cases decided by the European Court: Dudgeon v. United Kingdom, infra note 250, Norris v. Ireland, infra note 253, Modinos v. Cyprus, infra note 254.

${ }^{247}$ Steiner \& Alston, supra note 180 at 598.
} 
violation of their right to privacy by a particular provision of law, need to show that "they run risk of being directly affected by it" and demonstrate "effects of the laws on their lives."

In our case, the "victims" of the alleged violation, are women and men of reproductive age, who would take advantage of sterilisation as a contraceptive method, but cannot do that due to the existence of criminal law provision, ${ }^{2+9}$ resulting in the inaccessibility of this service, and doctors, who are potential and actual providers of this service. The interference of the state, in principle, constitutes of making the performance of sterilisation a criminal offence. The state of affairs explored below is the direct effect of this regulation.

In the section concerning nature of the alleged violation, I have outlined the potential effects of the outlawing of sterilisation as a contraceptive method, such as: depriving individuals of the choice to have a sexual relationship free from constant fear of unwanted pregnancy. Such advantage could contribute to the development of intimacy and fostering of the relationship. The restriction may also, as stated there, result in "enforced child-bearing" or force them to seek illegal, and, thus, potentially unsafe medical procedures. Furthermore there are the harmful aspects of criminalisation - stigmatisation of the procedure: sustaining a negative representation of the procedure, not allowing for a fully open popularisation of the method, misunderstandings about its effects, advantages and disadvantages, stigmatisation of the person who undergoes this.

This category of indirect effects of legal provisions, as opposed to the criminal prosecution, has been discussed by the European Court, among others, in the case of Dudgeon $\mathrm{v}$. United Kingdom, ${ }^{250}$ in which a homosexual complained that "he has experienced fear, suffering and psychological distress directly caused by the very existence of the laws in question [criminalising homosexual sexual activities between consenting adults]."2s1 In his dissenting opinion, Judge Matscher argued that the fact that the law has not been executed for many years and that organisations advocating on behalf of the rights of homosexuals were able to function without greater restraints, puts into question the claim of "fear, suffering and psychological

\footnotetext{
248 Johnston v. Ireland (1986), . App. No. 9697/82, 112 Eur. Ct. H.R. (Ser. A), 9 E.H.R.R. 203.

${ }_{299}$ Art. 156(1) of the Criminal Code, supra note 1 and accompanying text. The interpretation of this provision and its implications was analysed in detail in Chapter II, Part A, above.

${ }^{250}$ Dudgeon v. United Kingdom (1981), 45 Eur. Ct. H. R. (Ser.A), 4 E.H.R.R. 149.
} 
distress." He concluded that the applicant and the organisations supporting him were seeking more; they were seeking the express and formal repeal of the laws in force, that is, a "'charter' declaring homosexuality to be an alternative equivalent to heterosexuality". ${ }^{252}$

In my view, the assessment of Matscher J. of what victims of the alleged violations in the case of Dudgeon have hoped for, is not mistaken. Similarly, in the case of sterilisation. the expectation from arguing the violation of the right to privacy is the repeal of the law, or rather. since the impugned provision has a much broader scope of application, the clarification - in the form, preferably, of the legislation concerning specifically conditions of performing the voluntary sterilisation - that this provision does not concern voluntary sterilisation. The result. however. of such decriminalisation is also that the procedure. as no longer criminal. becomes an accepted method of family planning, and is not stigmatised. The stigmatisation by the criminal sanctioning of this procedure is what constitutes. among others, an interference with the right to privacy.

Matscher J. in his opinion has also raised another issue concerning the interference of the state. He claimed that the lack of prosecution by state authorities is the evidence that there has been no interference with the right of privacy. The lack of enforcement of criminal sanctions or any other individual measure against the complainant has also been discussed in the cases of Norris v. Ireland $d^{253}$ and Modinos v. Cyprus ${ }^{254}$. In the latter, the Commission stated:

the mere fact that the implementation of a penal law has not led to the criminal convictions, does not of itself negate the possibility that it has effects amounting to interference with private life. A primary purpose of any such laws is to prevent the conduct it proscribes, by persuasion or deterrence. It also stigmatises the conduct as unlawful and undesirable. ${ }^{\text {is }}$

231 lbid para. 37 at 160 .

32 Ibid. Dissenting Opinion (Judge Matscher) para 11-12 at 176.

${ }^{25 s}$ Norris v. Ireland (1989), App. No. 10581/83, 142 Eur. Ct. H.R. (Ser. A), 13 E.H.R.R. 186. The applicant, an Irish national and a homosexual, claimed that Irish legislation penalising certain homosexual acts in private between consenting male adults violated his right to respect for his private life under Article 8 of the Convention.

${ }^{34}$ Modinos v. Cyprus (1993), App. No. 15070/89, 259 Eur. Ct. H.R. (Ser. A), 16 E.H.R.R. 485. The applicant, who was a homosexual, complained about the Cypriot law, which rendered homosexual conduct in private between consenting adults a criminal offence. He claimed that it violated his right to respect for his private life, notwithstanding the policy of the Cypriot Attorney General not to prosecute the offence.

3s lbid para. 36 at 490. 
In the Norris case the European Court decided that the interference with the right might be taking place even if the risk of prosecution was minimal. It also stated:

A law which remains on the statute book, even though it is not enforced in a particular class of cases for a considerable time, may be applied again in such cases at any time, if for example there is a change of policy.

In our case, even though the provision of criminal code has never been applied to prosecute a doctor performing sterilisation, the existence of the law prevents doctors from pertorming nontherapeutic sterilisation and obstructs access to this service by individuals. We can also distinguish the mentioned above homosexual cases from the anti-sterilisation case by pointing to the following factors. Homosexual behaviour takes place in private, thus, the probability of the state authorities finding about it and pursuing charges is not that great and the probability of prosecution is lesser than in the case of sterilisation performed illegally. Sterilisation needs to be performed more publicly, by a qualified physician. who has to put some mention of a procedure into a patient's records. Thus, the chances of public authorities to find out about such procedure are greater. Furthermore, public prosecutors have the power to initiate proceedings against medical practitioners, as long as the law remains unchanged. Since the power to do so rests in the hands of individual public officials. the possibility of execution can not be excluded. This is especially important, if we take into account the atmosphere which at present surrounds issues of reproductive health and services. Since 1993, gradual restrictions have taken place in this sphere. It started with restrictions on abortion law in 1993, later confirmed in 1997 by the Constitutional Tribunal. Another example might be a withdrawal of subsidies of oral contraceptives or the withdrawal of sex education from schools. In this atmosphere, unfriendly to a greater freedom in the sphere of reproductive rights, the next step could potentially be the enforcement of antisterilisation laws by bringing actions against physicians performing illegal sterilisations. In this perspective, the deterrent effect of ant-sterilisation law is even stronger.

\section{(2) Proscription by law}

The restriction imposed upon the right on privacy, which is not proscribed by law, constitutes violation of the right to privacy. In the Open Door Counselling and Dublin Well 
Women v. Ireland ${ }^{256}$ case the European Commission submitted that the injunction on the provision of information concerning abortion services available abroad cannot be said to be proscribed by the general provision of the Irish Constitution concerning the protection of life from the moment of conception. In the Court's proceedings, however, it was decided, based on taking into account the overall protection given to unborn life in the Irish legal order, that the injunction was imposed in accordance with law, but that it was not necessary in the democratic society. In the case of the Polish Criminal Code provision applicable to sterilisation, ${ }^{257}$ as discussed in Chapter II, it has been argued by some Polish legal authorities. that this article does not apply to the case of voluntary sterilisation for contraceptive purposes. If the individual case of prosecution against the doctor performing sterilisation took place in Poland (in the case of Open Door - there was a specific injunction), one might consider arguing that this particular prosecution was not prescribed by law. I do not intend to pursue this line of thinking, because I do not find the arguments that the provision of Criminal code does not apply to sterilisation. convincing enough. However, it is another option, a different approach which could potentially be taken is argue that this measure is not prescribed by law.

\section{(3) Grounds for justification of the intervention}

The European Commission in the Briggemann II pronounced:

In principle, ...whenever the State sets up rules for the behaviour of the individual within this sphere, it interferes with the respect for private life and such interference must be justified in the light of Article 8 (2). ${ }^{2 s}$

The enormous, in my view, benefit of pursuing proceedings before the European Commission and Court of Human Rights, in particular in cases touching upon such "sensitive areas" as women's rights or reproductive rights, is that of challenging the state to make explicit the justifications of the laws that have existed in the domestic order of the country and

\footnotetext{
256 Open Door Counselling and Dublin Well Women v. Ireland, (1992), App. No. 14234/88 \& 14235/88, 246 Eur. Ct. H. R. (Ser. A), 15 E.H.R.R. 244 [hereinafter: Open Door].

${ }^{257}$ See supra note $I$ and accompanying text.

${ }^{258}$ Brïggemann II, supra note 183, para. 55 at 252.
} 
sometimes "survive[d] [only] by their stamp of unchallengeability" ass and not for rational reasons.

The task of identifying the justification for the alleged interference with the right to privacy falls upon the government. If the state does not provide any justification, the Court will assume that the interference cannot be justified and, thus, that the violation of the right to privacy ias taken place, as it has happened in the case of Modinos :. Cypras. ${ }^{260}$

In conclusion, the Polish government, in order to justify anti-sterilisation law, would have to identify one or more of the grounds as provided by Article $8(2)$ to justify its intervention in the sphere of privacy.

(4) Necessary in a democratic society - competition between the doctrine of the margin of appreciation and the promotion of the "European consensus"

Whenever the government brings forward a justification for the imposed restriction. it has to be verified whether this restriction is "necessary in the democratic society" for the advancement of the pursued goal. The most general indicators in the jurisprudence of the European Commission and Court as to the interpretation of this expression have been expressed by the Court in the Dudgeon ${ }^{261}$ case:

"[N]ecessary" in this context does not have the flexibility of such expressions as "useful". "reasonable" or "desirable", but implies the existence of a "pressing social need" for the interference in question..$^{262}$

Further, the Court introduces the concept of the "margin of appreciation":

[I] $\mathrm{t}$ is for the national authorities to make the initial assessment of the pressing social need in each case; accordingly, a margin of appreciation is left to them. ${ }^{203}$

The Court immediately makes a reservation about the "margin of appreciation" by stating:

However, their [national authorities'] decision remains subject to review by the Court."20-

\footnotetext{
359 Rubenfeld, supra note 176 at 759.

360 Modinos, supra note 254.

261 Dudgeon, supra note 250.

${ }^{262}$ Ibid. para. 51.

${ }^{263}$ Ibid. para. 52.

${ }^{20+1}$ lbid.
} 
And finally: "[A] restriction on a Convention right cannot be regarded as "necessary in a democratic society' ... unless, amongst other things, it is proportionate to the legitimate aim pursued."265

Application of these general rules has been. probably, one of the most extensively discussed issues - both in the jurisprudence of the European Commission and Court and by the scholarly writing, as it allows for a lot of different interpretations and applications in particular circumstances and allows for a lot of discretion for the European organs.

In the case of Toonen v. Australia. ${ }^{260}$ before the HRC. a similar test has been employed. which has been based on the concept of the restriction being "reasonable in particular circumstances," introduced in the General Comment 16 of HRC on Article 17 of the Political Covenant::267

The [Human Rights] Committee interprets the requirement of reasonableness to imply that any interference with privacy must be proportional to the end sought and be necessary in the circumstances of any given case. ${ }^{-0 s}$

Jacques Velu in 1973 argued that the determination of the necessity of the particular measure should be decided on basis of the "criteria generally adopted in democratic societies." 269 This was, at the time, in a firm opposition to the opinion of the Commission expressed. for instance, in the case of $X$ v. United Kingdom ${ }^{270}$ decided in 1975 , where the Commission put forward:

A measure may be "necessary ..." even if it is not applied in other European countries. It must be examined on its own merits ${ }^{71}$.... [W] $[\mathrm{W}$ ht is important is not the balance struck in other European countries, but the reasonable and objective nature of the arguments adduced in favour of [the

\footnotetext{
205 lbid. para. 53.

200 Toonen, supra note 245.

${ }^{267}$ See supra note 242 and 243 and accompanying text.

${ }^{208}$ Toonen, supra note 245, para. 8.3 .
}

$209 \mathrm{~J}$. Velu "The European Court of Human Rights and the Right to Respect for Private Life, the Home and Communications" in A.H. Robertson, ed., Privacy and Human Rights (Manchester: University Press, 1973) 12 at 72.

${ }_{270} X$ v. United Kingdom, App no. 7215/75, (1978), 19 Eur. Comm. H.R. D. R. (D \& R) 66. The case concerned a homosexual, who was accused of homosexual acts with two eighteen year old men and complained that the age of consent - different for homosexual and heterosexual acts - is discriminatory and that it is a violation of the right to respect for private life.

27 lbid. case summary at 66 . 
restriction $]^{22}$.... [It must be decided] in the context of the society for which it is considered appropriate. ${ }^{27}$

Velu's opinion has also been then in the contradiction with the then application of the doctrine of the "margin of appreciation" which requires the European organs to deter to the judgement of the national authorities, and which, at the early stages of the functioning of the European organs has been applied generously. ${ }^{274}$

In the Dudgeon ${ }^{275}$ case, we can really see the tension between these two approaches - the deference to the discretion of the national authorities. on the one hand. and the will to promote the progressive development of the human rights protection. requiring from the State to comply with the "European consensus" (the consistency between European countries as to the way the particular issue is resolved in their domestic policies). The Court in Dudgeon talks about the necessity to give the wide margin of appreciation to the national authorities in the matters of protection of morals, the aim, which has been pursued by the United Kingdom authorities as the justification for maintaining the prohibition of the sexual conduct in Northern Ireland. ${ }^{276}$ For this reason, the Court is lead to conclude that the fact that there exists the discrepancy between regulations in the Northern Ireland and other parts of the United Kingdom as well as other Member States of the Council of Europe does not settle the question whether the restrictions are not necessary in this particular case. On the other hand, one of the reasons the Court decides against the restrictions being unnecessary is the "marked changes which have occurred in this regard in the domestic law of the member States." 277 This is only one of the factors that have lead to such conclusion. Other factors include: lack of enforcement of the impugned laws and the lack of proportionality between the interests of state in pursuing its justification and the detrimental effects of the law on "victims".

\footnotetext{
272 lbid. para. 147 at 76.

${ }^{2 \pi}$ lbid. para 148 at 77.

${ }^{77 t}$ See e.g. P.J. Duffy "The Protection of Privacy, Family Life and Other Rights under Article 8 of the European Convention on Human Rights" (1983) 2 Yearbook Eur. L. 191 at 237. The reason given is the need for the Commission to build confidence among member States.

${ }^{275}$ Dudgeon, supra note 250.

${ }^{276}$ Ibid. para. 52 at 164.

27 lbid. para. 60 at 167.
} 
The Court referred in Dudgeon in support of its dynamic interpretation of the European Convention to another milestone decision, which demonstrates the change in the approach taken by the Convention's organs - Marckx v. Belgium ${ }^{278}$-- in which the Court decided to confer on Belgium the adoption of the principle - mater semper certa est, which has been accepted in "the domestic law of the great majority of the member States of the Council of Europe, in company with the relevant international instruments." ${ }^{279}$ From these three judgements: $Y$ v. United Kingdom, Dudgeon v. United Kingdom and Marckx v. Belgium, we could infer some guidelines as to the way the Court and Commission can interpret the meaning of the expression "necessary in the democratic society". First of all, the Commission and Court give respect to the doctrine of margin of appreciation, allowing the national authorities to provide with the reasoning concerning the link between the impugned restriction and the propounded ground for its justification, so that they can demonstrate the "pressing social need" for the existence of the restriction and proportionality between the way the restriction affects the lives of individuals and the aim pursued. Particularly with regard to the protection of morals. the European organs allow for the wide margin of appreciation. ${ }^{280}$ Furthermore, the Court and Commission take into account the way the particular issue is resolved in domestic laws of different member States. In the case of Dudgeon, as it concerned Northern Ireland, an important factor was the solution to this problem in other parts of the United Kingdom. Similarly, in the case of Toonen v. Australia. before the Human Rights Committee, the fact that other states of Australia have changed their legislation concerning homosexual relations, has played an important role. This may suggest that the special weight would be paid to the solution adopted in those countries that are in a similar situation, linked geographically, and supposedly also culturally. It seems, however, that the fact that there exists the discrepancy in solution adopted in one country and that adopted in other member States might not be a sufficient argument for the European organs to pronounce

27 Marckx, supra note 208.

279 Ibid. para. 41 at 346.

${ }^{280}$ Supra note 276 and accompanying text. 
violation. ${ }^{281}$ There must be some additional arguments in favour of the dynamic interpretation, especially since the way this interpretation has been justified by the European Commission and Court in particular cases has been subjected to a lot of criticism. ${ }^{282}$

The elements that turn the scale in favour of employing a dynamic interpretation, as pointed in the Dudgeon and Marckx cases are: in Dudgeon - the lack of enforcement of the impugned legislation, failure in the test of proportionality between the harm caused and the goals pursued, and, in Marckx, the development of international consensus - as demonstrated by reference to domestic laws and international conventions. Other examples suggested by authorities. on the basis of the review of the jurisprudence of the Court and Commission. which evidence the development of the international consensus are: regional legislation (resolutions and recommendations of legislative and executive branches of the Council of Europe), expert consensus and European public consensus. ${ }^{283}$ The elements spoken of above advocate in favour of pronouncing the restrictions imposed by the country in question as unnecessary in the democratic society. On the other hand, there are elements, which despite the fact that the legislation of the country might be out-of-line of the solutions widely accepted elsewhere. may decide in favour of accepting that the particular circumstances in the country make the discussed measure necessary in this country. One of the elements has been mentioned earlier - the character of the aim, which justifies the imposing of the restriction. In Dudgeon. specifically, it was the fact that the country has justified the restriction on the ground of promoting morality. ${ }^{2 s+}$ Other factors that the Court and Commission take into account in deciding the degree of the margin of

281 C.J. Forder "Legal Protection under Article 8 of the European Convention on Human Rights: Marckx and Beyond" (1990) 37 Netherl. Int'l L. Rev. 162 at 169.

${ }^{282}$ See e.g. Helfer, supra note 182 . Helfer criticises the fact that there is ambiguity in the European organs' employment of the "consensus methodology" - the inquiry as to the degree to which the "European consensus" on the particular issue at stake has been developed. He criticises that there is no doctrine or principles developed on how much weight should be given to various factors demonstrating the development of such consensus and suggests that the structural/textual interpretation should be always given priority. See also Forder, ibid.

${ }^{283}$ Helfer, ibid. at 139. Helfer gives examples of cases, in which each of the mentioned by him categories of evidence has been referred to by the Commission or Court.

234 Supra note 276 and accompanying text. 
appreciation left to the national authorities are: the nature of the activities involved ${ }^{285}$ and the human right at issue ${ }^{286}$.

Finally, the international tribunals consider the question of proportionality between harms imposed by a measure and the interests that state aims to protect and the harms that could result from the lack of the measure. In doing so, a weighing of the harms needs to be conducted and the consideration whether therc arc any other fcasible solutions to the problem - any less restrictive means through which the state's goals could be achieved. As the case of Open Door ${ }^{287}$ demonstrates, some additional factors in the proportionality test are: whether the application of the impugned legislation is not broader in its effects than necessary for the achievement of its goal. whether the measure applied is actually effective for the achievement of the goal, and whether the restriction does not affect in a more drastic way some more vulnerable groups of the society. In Open Door, the restraint imposed on applicants from imparting and receiving any information concerning abortion facilities outside of Ireland. was disproportionate to the aims pursued because: "the injunction limited the freedom to receive and impart information with respect to services which are lawful in other Convention countries and may be crucial to a woman's health and well-being." injunction sought to restrict was already available elsewhere ...[and] the injunction appears to have been largely ineffective in protecting the right to life of the unborn since it did not prevent large numbers of Irish women from continuing to obtain abortions in Great Britain."

\footnotetext{
${ }^{285}$ Dudgeon, supra note 250, para.52. In the Dudgeon the Court decided that since the case concerns "the most intimate aspect of private life, ... there must be particularly serious reasons [for] interferences ...".

${ }^{286}$ Helfer, supra note 182 at 144 . See also ibid. at 159 , where Helfer refers to the right to privacy as belonging to the group of such rights. The rationale given by him is two-fold. First, some of the Convention rights, including the right to respect for private life have the "exclusive list of rationales upon which the states may rely to restrict the exercise $f$ the right" (referring to Art. 8(2)). Second, in his view, the concept of "necessary in a democratic society" implicates that the state needs to respond to the evolution that the democratic society continuously undergoes.

${ }^{237}$ Open Door, supra note 256.

288 lbid para. 72 at 266.

${ }^{239}$ Ibid., para. 76 at 267.
} 


\section{PART D. The Right to "Equality"}

\section{Introduction}

The suggestion that laws restricting reproductive freedoms may violate the right to equality has been made by Sylvia Law in the article "Rethinking Sex and the Constitution." 190 This thought has been also developed by Rebecca Cook, who submitted:

When governments fail to reform laws and policies that discriminate against women such as:

-... laws that have a differential impact on girls, such as parental authorization requirements for adolescents to obtain reproductive services. or

- laws that criminalize medical procedures that only women need, such as abortion. ... they are in violation of their obligations to bring their laws into compliance with the human right to sexual non-discrimination. ${ }^{291}$

The criminal ban on sterilisation is not discriminatory, neither on its face nor in its application. Although. as we know, the law has never been enforced against somebody performing sterilisation, nevertheless, in theory, the proscription applies equally to men and women. Despite the fact that, according to the anecdotal data, sterilisation is used more often by women than men, the deterrent effect of this prohibition can be said, in general. as applying to both genders. ${ }^{292}$ However, we should now focus on, the link between access to contraceptive options and the situation of women.

The thesis, that I want to pursue in this section is that the prohibition of sterilisation has a disproportionate adverse and discriminatory impact on women. I will analyse this statement in more detail and look at whether this claim allows to argue a violation of the right to equality in international law, and what difficulties this argument would have to overcome.

\footnotetext{
290 S.A. Law, "Rethinking Sex and the Constitution" (1984) 132 U. Pa. L. Rev. 955.

291 R.J. Cook, "Human Rights Law and Safe Motherhood" (1998) 5 E. J. Health L. 357 at 366.

292 The fact that it is women, who undergo the majority of illegal sterilisations, and not their partners has been mentioned in Chapter II, Part A, above. See text accompanying note 37. This can be, as argued there, at least in some part attributed to its illegality. Its popularisation among men can have some impact on the status of women, as it has been discussed in Chapter II, Part C, above. For further analysis of this issue, see also below, in this part.
} 


\section{Spelling Out the Problem}

What is it about sterilisation that allows me to claim that its prohibition adversely and in a discriminatory way affects women? The answer to that question is premised on the observations made earlier in the part concerning harms. Sterilisation is one of the most widely used methods of contraception in the world. It is used by hoth men and women. In fact. the benefits of this method - the "absolute" prevention of unwanted pregnancies - are shared by both women and men, supporting their ability to shape their lives according to their plans, resources, and capabilities. However. in the case of an actual unwanted pregnancy - when contraceptive means are not used or when they fail. the burden of it cannot be said to be fully equally shared by both parents. First. "[n]ature demands that women alone bear the physical burdens of pregnancy." ${ }^{293}$ These burdens include: physical burdens of the pregnancy and birth. attendant health risks. as well as, in most cases. the inability to carry on wage-work at least for a certain period during pregnancy and immediately following it. These circumstances are attributable to the biological difference between the sexes. ${ }^{.94}$

Besides the unequal situation which results from the biological difference, there are further consequences for women of the inaccessibility of effective contraceptive alternatives. These take place after birth and are not directly linked to biology, but rather to social and cultural expectations about the role of mothers in taking care of children. These expectations are still significantly greater than those expected from the role of the father. ${ }^{195}$ As Sylvia Law observes:

Biology does not determine who cares for a child after birth. [When we assume so. we confuse] biology with social patterns and sex-based stereotypes. ${ }^{2 \%}$

$: 93$ Law, supra note 290 at 1016.

29 D. Greschner, "Pregnant with Meaning" Discourse, Democracy, and the Daigle Decision" in L. Samueison, ed., Power and Resistance: Critical Thinking About Canadian Social Issues, $2^{\text {nd }}$ ed. (Halifax: Fernwood, 1998) 155 at 157. Greschner argues "The regulation of reproduction will affect women more than men; pregnancy, abortion and birth are experiences for which men have no analogy."

${ }^{295}$ Sylvia Law observes that the birth of a child will not necessarily affect each and every woman in the same way, because some of them can, immediately after giving birth, leave the child - either for adoption or for the care of other members of their families. Law submits "It is not unheard of for a woman, after giving birth, to simply walk away.", see supra note 290 at 993.

${ }^{39} \mathrm{lbid}$ at 996 . Of course, we should not completely ignore the fact that women can breast-feed a child, while men cannot. However, this is also not true about all women, and this is also not necessary (even if recommended) for the survival of a child nowadays. 
Whether we attribute the fact that women take more responsibility for child-rearing to biology or social expectations, the effects of it are the same - the life of a woman in the majority of cases changes much more significantly because of pregnancy than the life of a man. In a lot of cases women do not start or continue wage-work. education or other activities that they may have planned or that they had been pursuing before becoming pregnant. These impair career advancement or other goals women may have. The problem has been emphasised forcibly in the General Comment 21 of the Committee for the Elimination of Discrimination Against Women, Equality in marriage and family relations, which reads:

21. The responsibilities that women have to bear and raise children affect their right of access to education. employment and other activities related to their personal development. They also impose inequitable burdens of work on women. The number and spacing of their children have a similar impact on women's lives and also affect their physical and mental health. as well as that of their children. For these reasons, women are entitled to decide on the number and spacing of their children. ${ }^{297}$

The Polish legal system recognises this problem by giving particular guarantees to women, such as, the guarantee that they be able to return to the same job after matemity leave and the employer's obligation to allow female employees to take breaks for breast-feeding. ${ }^{298}$ Nevertheless, in Poland, two things must be kept in mind. First. these guarantees might not be fully effective because of the difficult situation on the labour market in Poland generally, and the high unemployment rate among women. Thus, a lot of these guarantees exist on paper but not in practice. Furthermore, they will apply only to those women who already had a job before getting pregnant, and only to contracts of employment (as opposed to increasingly common "independent contractor" arrangements). This excludes from a full protection women, who have not been employed before getting pregnant, or who had part-time, casual, or non-contractual work relations.

Thus, when a mother start work or other activities, they effectively end up having two "jobs" - wage-work and house-work. Men, on the other hand will not have to compromise their life plans and stay at home and take care of children. They will not, in most cases, be affected as

\footnotetext{
297 GR 21, supra note 100.

${ }^{298}$ It is regulated by the Polish Labour Code.
} 
much by the birth of a child as women will, both in terms of the ability to work and pursue a career and in terms of having double the work - at both wage-work and home. An immediate reaction to these statements is that the burdens of child-rearing can, and ideally should, be shared by both parents. In fact, in some families these burdens are equally shared by parents or, in more rare cases it is the fathers who take more responsibility for bringing up and caring for children. However, the present situation in Poland and the practical reality in the prevailing majority of Polish families is that women still carry most of the burdens associated with child-care and home-care. However, neither labour market protections nor changing norms regarding child care responsibilities are complete answers to the disproportionate burden of pregnancy on women. This is especially so with regard to the biology-dependent effects of the pregnancy itself. With regard to socially-dependent effects. substantial progress cannot be expected to happen immediately. For this reason, other guarantees and responses are necessary, including comprehensive access to contraception.

As Sylvia Law states, regulating access to contraceptives can "either mitigate or exaggerate the costs of these burdens. "299 Access to contraception, even where it is accessed by men gives women the ability to take more control over their lives and to be able to pursue their plans. It allows women to choose, when and how many children to bear. In this way, access to contraception puts women on a more equal footing with men, in their ability to take advantage of opportunities given by education, work, public life, in achieving higher economic and social status. This link between the status of women and the access to effective contraception has been emphasised for many years in, among others, the work of the United Nations. As stated in a 1973 report prepared for the UN Commission on the Status of Women:

[T] he ability to regulate the timing and number of births is one central means of freeing women to exercise the full range of human rights to which they are entitled..$^{300}$

Thus, the link between contraceptive access and greater equality is not altogether novel.

\footnotetext{
299 Law, supra note 290 at 1016.

${ }^{300}$ See Report of the Special Rapporteur: Study on the Interrelationship of the Status of Woman and Family Planning, U.N. ESCOR, Comm. on the Status of Women, 25 ${ }^{\text {th }}$ Sess. para. 31, U.N. Doc, E/CN.6/575/Rev.1 (1973) cited in "International Protection", supra note 171 at 683-684.
} 
One can argue that criminalisation of sterilisation does not lead to a lack of contraceptive options. In fact, the argument goes, other legal contraceptive alternatives, that are non-permanent - e.g. those that are more often used to delay the first pregnancy or to space pregnancies - suffice as adequate access to contraception. However, on the other hand, sterilisation nearly guarantees and, hence, facilitates other life plans after having the last child. Moreover, criminalisation of sterilisation limits the range of available options, which. as pointed out in the previous chapter. may already be limited by other circumstances: health condition. age or resources.

The criminalisation of sterilisation limits access to a service which is predominantly needed by and beneficial to women to enable them to have equality of opportunities to pursue their life-plans and their rights to self-determination. education and participation in public life. This prohibition has an adverse, discriminatory effect on women by denying them opportunities to a life more equal with men, and by not protecting them from the consequences of unwanted pregnancies.

\section{The Response of International Law}

The right to equality in International Law is provided in two documents to which Poland is a party: the European Convention - Art. 14, ${ }^{301}$ and the Political Covenant - Art. 2, 3, and 26. ${ }^{302}$ The question here is whether these protections recognise and encompass the kind of the harm I have described above.

\footnotetext{
${ }^{301}$ European Comvention, supra. note 131. Art. 14: The enjoyment of the rights and freedoms set forth in this Convention shall be secured without discrimination on any ground such as sex, race. ..., religion, ....

302 Political Covenant, supra. note 127.

Art. 2. I Each State Party to the present Covenant undertakes to respect and ensure to all individuals within its territory and subject to its jurisdiction the rights recognized in the present Covenant, without distinction of any kind, such as race, colour, sex, ....

Art 3 The States Parties to the present Covenant undertake to ensure the equal right of men and women to the enjoyment of all civil and political rights set forth in the present Covenant.

Art. 26 All persons are equal before the law and are entitled without discrimination to the equal protection of the law. In this respect, the law shall prohibit any discrimination and guarantee to all persons equal and effective protection against discrimination on any ground such as race, colour, sex, ....
} 
The definition of what constitutes discrimination under Art. 14 of the European Convention was developed in Belgian Linguistics case ${ }^{303}$ and reaffirmed in subsequent cases. According to this definition, discrimination occurs when a law makes a distinction which results in the differential treatment of certain groups, and which does not have an objective and reasonable justification. If the distinction has an objective and reasonable justification, it will not constitute discrimination unless, the requirement of proportionality between the means employed and the ends sought to be realised by pursuing this distinction is met.

In the case of Abdulaziz, Cabales and Balkandali v. United Kingdom ${ }^{30+}$ (Abdulaziz), for instance, the European Court. after analysing the case according to the Belgian Linguistics's test. found that English law made an explicit distinction in immigration laws, in that it treated men and women differently, and that this distinction constituted gender discrimination. which was not justified by reasons pursued by the government. According to the immigration rules in question. men residing in other countries were not able to come to the U.K. to join their spouses and settle lawfully in the U.K.. where women were lawfully and permanently settled in the U.K.. At the same time, men who were permanent residents of the U.K.. could be joined legally by their wives coming from other countries. The Court decided that this distinction constituted a violation of Art. 14.

The Abdulaziz case concerned direct discrimination. The distinction was made explicitly on the face of the law. The different treatment of two sexes was directly attributable to the application of law. This category of discrimination has been also recognised under the Political Covenant. One example is the decision of the Human Rights Committee in the case of Broeks $v$. The Netherlands..$^{305}$ In this case, the law discriminated against married women by requiring from

\footnotetext{
${ }^{303}$ Belgian Linguistics, supra note 216. See e.g. Harris, O'Boyle \& Warbrick, supra note 175 at 475 . The authors state: "The language [the Belgian Linguistics case] used has stood up various challenges made to it since and still represents the core of the Convention meaning of discrimination."

${ }^{304}$ Abdulaziz, Cabales and Balkandali v. United Kingdom (1985), 94 Eur. Ct. H. R. (Ser. A) 7 E. H. R. R. 471 [hereinafter: Abdulaziz].

${ }^{305}$ Broeks v. the Netherlands (1987), Communication No. 172/1984, U.N. GAOR, 42 ${ }^{\text {nd }}$ Sess., Supp No. 40, para. 13, U.N. Doc. A/42/40, Yearbook of the Human Rights Committee 1987, vol. II (New York: UN, 1994) at 293 [hereinafter: Broeks].
} 
them, but not from married men, to prove that a woman was a "breadwinner" in order to qualify for the unemployment benefit.

Broeks highlights one issue that is of great importance for our case; that is, that in order to establish discrimination, it is not necessary to prove that the law was intentionally discriminatory. ${ }^{306}$ The Human Rights Committee acknowledged the facts as submitted by the Dutch government that the legislation "was inspired not by any desire to discriminate in favour of men and against women but by the de facto social and economic situation which existed at the time when the Act was passed ..." ${ }^{307}$ Nonetheless, the Human Rights Committee decided that it was sufficient to determine that the effect of the legislation was discriminatory in applying differently to men and women. in order for it to constitute violation of the right to equality guaranteed in Art. 26 of the Political Covenant. ${ }^{308}$

This is fundamental to showing that sterilisation prohibition are discriminatory. Although it is difficult to trace precisely back the historical rationale for this legislation. the present justifications may be seen as touching the issues of the protection of morals, public health. national economic well-being of the country, and protecting against the abuse of this procedure. It would be extremely difficult to support the claim that the law in this case is intentionally discriminatory. However, as I have argued earlier, it results in discriminatory adverse effects for women.

Moreover, in the case of sterilisation we are dealing with an even more complicated species of discrimination than the ones that have taken place in: Abdulaziz and Broeks. The law on sterilisation is neutral on its face. It is also applied in a non-discriminatory manner to both genders; indeed it prohibits vasectomies as well as tubal litigations. Furthermore, the law does not make a distinction between two groups of people, and does not treat them differently. The only source of discrimination, therefore, is that the risks of non-comprehensiveness in contraceptive choice are borne disproportionately by women.

\footnotetext{
${ }^{306}$ See also A. F. Bayefsky, "The Principle of Equality or Non-discrimination in International Law" (1990) 11 H. R. L. J. 1 at 8-10.

${ }^{307}$ Broeks, supra note 305 , para. 8.4 at 296.

${ }^{308}$ Ibid. para. 14-16 at 297.
} 
The issue of the indirect discrimination has been subject to the jurisprudence of the European Commission and Court, as well as the Human Rights Committee. The cases in which the issue has been discussed need to be scrutinised closely before it is possible to draw any conclusion as to whether this kind of impact of the impugned law could be considered as the violation of the right to non-discrimination.

Under the European Convention. Abdulaziz case, ${ }^{309}$ besides the gender inequality discussed earlier, has also involved the question of the adverse effect discrimination on the ground of race. In a dissenting opinion, three members of the European Commission indicated that the immigration requirement that the parties to the marriage must have met had an adverse effect on women residing in the U.K. wishing to marry men from the Indian sub-continent. because arranged marriages were a popular practice in this region and not in other regions of the world. The dissenting Commissioners argued that this requirement "by [its] practical side effect ... [was] indirectly racist. ${ }^{-310}$ This would imply that the case was one of the adverse effect discrimination. The European Court, however, following the majority in the Commission did not held this as the violation of Art. 14 discriminatory on the ground of race.

The Court has based its decision on the following premises. First of all, it stated:

[S]uch a requirement [of previous meeting] cannot be taken as an indication of racial discrimination: its main purpose was to prevent evasion of the rules by means of bogus marriages or engagements. ${ }^{311}$

This remark is very unfortunate. It could lead to the a priori conclusion that the adverse effect discrimination could not be considered discrimination under the European Convention, without directly analysing the merits of the issue itself. The Court has turned directly to the third - justification step of the analysis without first looking at the effects of the regulation. The Belgian Linguistics case $^{312}$ introduced the test requiring a three step analysis: (1) determination whether the law results in the different treatment of certain groups, (2) determination whether there is a legitimate aim - reasonable and objective justification, for the distinction, as forwarded

\footnotetext{
${ }^{309}$ Abdulaziz., supra note 304.

${ }^{310}$ Dissenting opinion of Mr. Carillo joined by Messrs Melchior and Weitzel, B 77 (1983-85) Com Rep at 46, cited in Harris, O'Boyle \& Warbrick, supra note 175 at 478.

31' Abdulaziz., supra note 304 para. 85 at 505.
} 
by the government, and, (3) finally, a balancing test between the measure and the proposed aim. ${ }^{313}$ The reasoning in Abdulaziz distorts these analysis by putting an undue emphasis on the public interest, giving inadequate attention to how the law influences the lives of individuals, and skipping the question whether the way the immigration law operated in this case could be held as a violation of Article 14. The Court should, in the first step, consider how the requirement of "previous meeting" applies to this category of people, and whether it results in adverse effect discrimination of this group. Only then, should the Court look at the justification forwarded by the government, and finally, undertake the balancing test. Fortunately for the proponents of the recognition of the adverse-effects discrimination. Abdulaziz has been interpreted as inconclusive as to whether adverse effect discrimination falls within the scope of Article 14 of the European Convention. ${ }^{314}$

Under the International Covenant, the case of indirect discrimination was considered in Singh Binder $v$. Canada. ${ }^{315}$ The case concerned a Sikh, whose religion necessitates wearing a turban regularly and who was dismissed because he refused to wear safety headgear at work as required by safety regulations. The applicant himself claimed a violation of Art.18 para. 1 of the Political Covenant - the right to freedom of thought, conscience and religion. However, the Human Rights Committee, on its own initiative, examined this issue in relation to Article 26 of the Covenant. The remarks of the Committee are somewhat laconic:

The Committee notes that in the case under consideration legislation which, on the face of it, is neutral in that it applies to all persons without distinction, is said to operate in a way which discriminates against persons of the Sikh religion. ${ }^{310}$

And, later:

\footnotetext{
312 Belgian Linguistic, supra note 216.

${ }^{315}$ Ibid. para. 10 at 284. See also Abdulaziz., supra note 304 at 472 (summary of the decision, para. 2(a)). See also S. Livingstone, "Article 14 and the Prevention of Discrimination in the European Convention on Human Rights" (1997) [1997:1] EHRLR 25 at 29.

${ }^{314}$ Harris, O'Boyle \& Warbrick, supra notel 75 at 478.

${ }^{315}$ K. Singh Binder v. Canada (1989), Communication No. 208/1986, U.N. Doc. A/45/40, Official Records of the Human Rights Committee 1989/90, vol. II (New York: UN, 1995) 398.

${ }^{316}$ lbid. para. 6.1 at 400.
} 
If the requirement that a hard hat be worn is seen as discrimination de facto against persons of the Sikh religion under article 26, then, applying criteria now well established in the jurisprudence of the Committee, the legislation [requiring wearing the safety headgear] is to be regarded as reasonable and directed towards objective purposes that are compatible with the Covenant. ${ }^{317}$

In this particular case, the legislation in question was found to be justified by the objective of protecting safety of workers, but, this does not have a bearing on the question of the scope of Art. 26. One should ask, however, how the phrase "is said to operate in a way which discriminates ..." is to be understood. Is it the opinion of the Committee - its view on the way the Political Covenant should be interpreted? Or is it only the statement referring to the author's claim? In this case, again, the more conclusive discussion concerning the adverse effect discrimination is missing. However, it seems that this decision is more supportive of treating adverse effect discrimination as falling within the scope of Art. 26.

In support of the view that the adverse effect discrimination should be considered as a violation of Art. 26 of the Political Covenant. Anne Bayefsky invokes the definition of the discrimination proposed by the Human Rights Committee in its General Comment 18, entitled "Non-Discrimination." ${ }^{18}$ This definition was inspired by definitions in two international treaties: Convention on the Elimination of All Forms of Discrimination Against Women ${ }^{319}$ and The International Convention on the Elimination of All Forms of Racial Discrimination. ${ }^{320}$ In the General Comment, the Committee stated that:

[T] he term "discrimination" as used in the Covenant should be understood to imply any distinction, exclusion, restriction or preference based on any ground such as: race, colour, sex, .... and which has the purpose or effect of nullifying or impairing the recognition, enjoyment or exercise, on an equal footing, of all rights and freedoms. ${ }^{321}$

This definition talks explicitly about the fact that the violation may result not only from the intentional discrimination, but also from the effect or impact of the law. It also talks very

\footnotetext{
${ }^{317}$ Ibid. para. 6.2 at 400.

${ }^{318}$ HRC, Non-discrimination: . 10/11/89. CCPR General Comment 18, online: UN High Commissioner for HR Webpage, supra note 140 [hereinafter: GC 18].

${ }^{319}$ Women's Convention, supra note 137.

320 International Convention on the Eliminaiton of All Forms of Racial Discrimination, 21 December 1965, 660 U.N.T.S. 195.

${ }^{321}$ GC 18 , supra note 318 para. 7.
} 
broadly about the scope of the impact of the law. According to this definition, it would be enough to establish that women were not able, because of the impact of the legislation, to enjoy, on an equal footing with men, various rights and freedoms, such as the right to education, selfdetermination, employment. And the evidence shows that:

"[i]f women are unable to decide on procreation matters, they will be deprived of benefits regarding 'their health. education or employment and their roles in family and public life' and inere wiil be very few and limited social options for them."

Further support for the recognition of this category of discrimination can be found in the case of Thlimmenos $v$. Greece ${ }^{323}$ decided by the European Court. In the case, the applicant - a Jehovah's witness - complained about the fact that he was not appointed as a chartered accountant. despite passing entrance exams with excellent results, on the ground that he has been convicted of a felony. His criminal conviction concerned insubordination for having refused to wear military uniform at the time of general mobilisation. The refusal to appoint him was fully authorised by law, which did not distinguish between different kinds of conviction for a felony. Everybody, who had been convicted for such offence would not be appointed to the profession. The complaint of the applicant concerned the fact that:

[I]n the application of relevant [neutral] law no distinction is made between persons convicted of offences committed exclusively because of their religious beliefs and persons convicted of other offences. ${ }^{34}$

The Court had to decide whether the law, which was neutral on its face. and applied equally to everybody was discriminatory on the basis of religious belief. The Court stated:

The Court has so far considered that the right under Art. 14 not to be discriminated against in the enjoyment of the rights guaranteed under the Convention is violated when State treat differently persons in analogous situations without providing an objective and reasonable justification... However, the Court considers that this is not the only facet of the prohibition of discrimination in Article 14. The right not to be discriminated against ...is also violated when States without an objective and reasonable justification fail to treat differently persons whose situations are significantly different. ${ }^{325}$

\footnotetext{
${ }^{32}$ M. Kirilova Eriksson, Reproductive Freedom (The Hague: Martinus Nijhoff Publishers, 2000) at 305.

${ }^{33}$ Thlimmenos v. Greece (2000), App. No. 34369/97, (unpublished at the time of writing this thesis, available online: European Court of Human Rights Webpage <http://www.echr.coe.int> (date accessed: September 21, 2000). 324 Ibid. para 42.

${ }^{325}$ Ibid. para. 44. [emphasis added]
} 
The Court has broadened the principle of equal treatment beyond its most narrow understanding treating alike cases in the same way - to include the requirement that cases that are significantly different should be treated with giving appropriate respect for these differences. The Court in Thlimmenos recognised persons convicted for an act through which they have been exercising their freedom of religion as a distinct group which merits special treatment. For this reason, it heid that the Greek state vioiated the right of an applicant to not be discriminated against by "failing to introduce appropriate exceptions to the rule barring persons convicted of a felony from the profession of chartered accountants." ${ }^{336}$

The significance of Thlimmenos is in the fact that the European Court has significantly broadened its understanding of the principle of discrimination to encompass laws that discriminate in a more indirect way. It has also emphasised the importance that the law must accommodate significant differences in order to be non-discriminatory. In the case on antisterilisation law the restriction is also neutral - applies in a non-discriminatory manner to both genders; indeed it prohibits vasectomies as well as tubal litigations. Similarly to Thlimmenos, we argue that there exists a significant difference between women and men - due to biological and sociological factors - which should be accommodated by the law. However, the feature that distinguishes this case from Thlimmenos, is that in the latter - the discriminatory effect was attributable to the application of law. While, in the former - we argue that the law should accommodate the pre-existing disadvantage. The only charge that can be made against the law is that it does not alleviate the pre-existing disadvantage and in this way, can actually exacerbate the unequal situation of women.

Another problem to overcome is that the Polish anti-sterilisation law itself does not make any distinction between men and women. Conceptually, it is a lot easier to identify discrimination if the law makes a distinction on its face between particular groups of the society. Other ways in which the law could work in a discriminatory manner are more difficult to

${ }^{326}$ Ibid. para. 48. 
conceptualise, describe and express. Some helpful guidance, in this respect, can be found in the Canadian case of Eldridge v. British Columbia (Attorney General). ${ }^{327}$

In Eldridge, a group of deaf persons argued that the failure to provide public funding for sign language interpreters in the delivery of health services infringed their right to the equal benefit of law without discrimination based on physical disability, contrary to section 15(1) of the Canadian Charter of Rignts and Freedums (the Churter). ${ }^{328}$ In upholding the slaim, the majority of Supreme Court of Canada, decided:

The failure to provide sign language interpreters constitutes discrimination in the provision of benefit. On its face, the Medicare system in British Columbia applies equally to the deaf and hearing populations. It does not make an explicit distinction based on disability by singling out deaf persons for different treatment... However, the Charter protects against adverse effects discrimination .... In this case, the lack of funding for sign language interpreters renders the 3 individuals unable to benefit from the legislation to the same extent as hearing persons.... [S]ign language interpretation should be viewed as the means $b v$ which deaf persons mon receive the same quality of medical care as the hearing population. $32 \dot{9}$

Although the public health care system did not make an explicit distinction between the two groups of people: deaf and hearing persons, the "distinction" can be traced in the categorisation of medical services. Before the case reached the Supreme Court of Canada, in the Court of Appeal, it was held that these interpretation services were not medically required, but had an ancillary character, and thus, did not have to be publicly funded..$^{330}$ However, this seems to be exactly the core of the distinction made by the system. As La Forest J., held, effective communication is an integral part of the medical service, for this reason, sign language interpretation, as necessary for the effective communication, is also necessary for the delivery of medical services. The distinction made by the system - excluding the sign language interpretation services from the medical services "seriously mischaracterizes the practical reality of health care delivery." ${ }^{331}$ La Forest J., for the Court, has invoked Lamer C. J.'s dicta in case of Rodrigue ${ }^{332}$ :

\footnotetext{
${ }^{127}$ Eldridge v. British Columbia (Attorney General) (1997), 151 D.L.R. (4t) (S.C.C.) 577 [hereinafter: Eldridge]. ${ }^{328}$ Charter, supra note 162. Section 15(1): "Every individual is equal before and under the law and has the right to the equal protection and equal benefit of the law without discrimination and, in particular, without discrimination based on race, ..., sex, ... or physical disability."

${ }^{329}$ Eldridge, supra note 327 , summary of the judgement at 580 . [emphasis added]

${ }^{330}$ lbid. para. 67 at 619.

${ }^{331}$ lbid. para. 69 at 619.
} 
Even in imposing generally applicable provisions, the government must take into account differences which in fact exist between individuals and so far as possible ensure that provisions adopted will not have a greater impact on certain classes of persons due to irrelevant personal characteristics ... ${ }^{j 3}$

Furthermore, La Forest J, also invoked the statement of McIntyre J. in Andrews v. Law Society of British Columbia that: ${ }^{334}$ "[A]ccomodation of differences is the true essence of equality." ${ }^{\text {" } 355} \mathrm{By}$ looking at the practical reality of health care delivery, the Supreme Court concluded that the interpreting service was necessary for deaf persons to enjoy, on the same level as those with hearing, the totality of health services offered. Ignoring this characteristic of the interpreting service constituted the discriminatory distinction made in the system of public funding for the health services.

In the case of criminalisation of sterilisation. the only facial distinction in law is made between the one particular contraceptive mean and other contraceptive means. as well as. between other health services that society can access. I have argued at the beginning of this section, that this service is disproportionately beneficial to women by enabling them to have equal opportunities to pursue their life-plans and to enjoy, on an equal footing with men, their rights to self-determination, education and participation in public life. Although it might not be possible to say categorically that sterilisation is absolutely necessary to achieve this goal, and that its legalisation will radically and immediately change the situation of women, nevertheless it is possible to link access to effective and safe contraception to increased freedom of choices and opportunities for women. The distinction made by the law between this service and other categories of services can be said to ignore the practical reality of women's lives, and as not paying full respect to their needs.

Applying Eldridge, one could argue that comprehensive contraceptive access is fundamental to women being free to access all the opportunities and fundamental personal choices available to men in modern society and economy. Less than full comprehensiveness.

\footnotetext{
${ }^{332}$ Rodriguez v. British Columbia (Attorney General) (1993), 107 D.L.R. $\left(4^{\text {th }}\right) 342,85$ C.C.C $\left(3^{\text {rd }}\right) 15,[1993] 3$ S.C.R. 519.

${ }^{333}$ Ibid. cited in Eldridge, supra note 327 at 617.

${ }^{334}$ Andrews v. Law Society of British Columbia, [1989] i S.C.R. 143.

${ }^{335}$ Ibid. at 169 cited in Eldridge, supra note 327 para. 65 at 617.
} 
especially imposed by criminal prohibition, risks compromising such access in the same way that a failure to accommodate the needs of the deaf to communicate compromises their access to opportunities for necessary health services.

The Eldridge case has also touched upon the other problem - mentioned above - the fact that the disadvantage discussed in this case, to which deaf people were subjected, was not directly the result of government action. In such a case, the government in Eldridge argued, the state "is not obliged to take positive actions, such as provide services to ameliorate the symptoms of systemic or general inequality." ${ }^{336}$ The response of the Supreme Court to this problem has been to point out that "once the state does provide a benefit, it is obliged to do so in a nondiscriminatory manner. ${ }^{" 337}$ Such a conclusion was possible in Eldridge. because it concerned access to services funded by the government. In our case, however, it would be more difficult to demonstrate that women are not able to access on the equal footing with men the benefits that are actually provided by the state.

Still. notwithstanding this deficiency, there are other arguments that speak in favour of holding the government accountable for the criminalisation of sterilisation as the violation of the right to non-discrimination. First of all, it has to be emphasised, that, although, the government is not the origin of the inequality, but rather it is the biological and cultural factors, by limiting access to a comprehensive range of contraceptive methods, nevertheless, the government still obstructs women in their own striving for equality, for improvement of their situation. By obstructing this progress, the government can be hold accountable for being the source of further inequality.

Furthermore, it is important to point out that the Polish government has accepted the obligation for positive action in the sphere of gender equality. This obligation stems from Article 3 of the Women's Convention:

\footnotetext{
${ }^{330}$ Eldridge, supra note 327 para. 73 at 621 . The respondents invoked in support of such view the case of Thibaudeau v. Canada (1995), 124 D.L.R. (4t) 449, [1995] 2 S.C.R. 627.

${ }^{337}$ Ibid. The Court referred to such decisions as: Tetrault -Gadoury v. Canada (Employment and Immigration Commission), [119] 3 S.C.R. 22, 81 D.L.R. $\left(4^{\text {th }}\right) 358$, Haig v. Canada (Chief Electoral Officer), [1993] 2 S.C.R. 995. At pp. 1041-42, 105 D.L.R. (4t) 577, Native Women's Assn. of Canada v. Canada, [1994] 3 S.C.R. 627 at 655, 119 D.L.R. $\left(4^{\text {th }}\right) 224$.
} 
States Parties shall take in all fields, in particular in the political, social, economic and cultural fields, all appropriate measures, including legislation, to ensure the full development and advancement of women, for the purpose of guaranteeing them the exercise and enjoyment of human rights and fundamental freedoms on the basis of equality with men. ${ }^{338}$

This provision might not compel specific state action, but it can still be invoked as a general policy commitment to the goal of substantive equality.

Similarly, the commitment to empowerment of women and promotion of equality was expressed in international consensus documents, such as: the Beijing Platform. ${ }^{339}$ Cairo Programme, ${ }^{3+0}$ and documents accepted in their review process - Beijing Plus Five ${ }^{3+1}$ and Cairo Plus Five ${ }^{342}$ documents. These documents are supportive of access to sterilisation, as they emphasise promotion of men's responsibility for family planning and sexuality, which can be facilitated by giving them legal access to male contraceptive methods. such as vasectomies. ${ }^{3+3}$ These documents, though. as not legally binding, can still also be invoked as a political commitment by the state for which it can be held accountable.

Finally, two General Comments of the Human Rights Committee contemplate that the principle of equality may require affirmative action. In General Comment 18: "Nondiscrimination" in paragraph 10 , the Committee expressed its view that:

[T] he principle of equality sometimes requires States parties to take affirmative action in order to diminish or eliminate conditions which cause or help to perpetuate discrimination prohibited by the Covenant. For example, in a State where the general conditions of a certain part of the population prevent or impair their enjoyment of human rights ... ${ }^{34}$

\footnotetext{
338 Women's Convention, supra note 137, Art.3.

339 "Beijing Platform", supra note 80 - see e.g. Mission Statement, para. 1: "The Platform for Action is an agenda for women's empowerment. It aims at ... removing all the obstacles to women's active participating in all spheres of public and private life ...".

$3+0$ "Cairo Programme", supra note 105 - see e.g. para. 4.1 - 4.29 (Women and Empowerment).

$3+1$ "Beijing Plus Five", supra note 84 - see e.g. para. $102 \mathrm{i}$.

${ }^{342}$ United Nations, Report of the Ad Hoc Committee of the Whole of the Twenty-first Special Session of the General Assembly (Addendum: Key Actions for the Further Implementation of the Programme of Action of the International Conference on Population and Development), A/S-21/5/Add.I - see e.g. para. B 43-45 concerning the empowerment of women.

${ }^{3+3}$ See e.g. "Cairo Programme", supra note 105 para. 4.27: "Special efforts [w]ould be made to emphasise men's shared responsibility and promote their active involvement in responsible parenthood, sexual and reproductive behaviour, including family planning; ...; prevention of unwanted and high-risk pregnancies ..."

${ }^{3+4}$ GC 18, supra note 318 para. 10.
} 
Similarly, in General Comment 28, the Human Rights Committee submitted, with regard to Articles 2 and 3 of the Political Covenant:

The State party must not only adopt measures of protection but also positive measures in all areas so as to achieve the effective and equal empowerment of women. ${ }^{3.5}$

All of these examples point to the positive obligation of states to eradicate and alleviate the disadvantaged position of women in a society. In my view, this positive obligation doctrine supports the existence of an obligation of the state not to interfere with women's efforts to help themselves. If the concept of the right to non-discrimination did not encompass the concept of adverse effect discrimination, it would denude equality of meaning as a principle. Decisions of European Court of Human Rights in Abdulazi $i_{2}^{346}$ and, in particular, in Thlimmenos ${ }^{3+7}$ as well as the Human Rights Committee's decision in Singh Binder, ${ }^{3+8}$ demonstrate that the possibility of arguing and including this category of discrimination is not closed. But more helpful guidance as to the reasoning that could be followed in such a case is to be found. for example, in the Canadian case of Eldridge. ${ }^{3+9}$

Furthermore, as Sylvia Law argues, the issue here does not concern the affirmative duty of the government to alleviate systemic inequality or to promote equality, duties. which would require government to expend resources when funding and delivering public programmes. ${ }^{350}$ In such a case, the government could argue that there are other issues that it needs to address as a priority, such as, for example, poverty. In the case of Poland's anti-sterilisation laws, we are dealing instead with the criminalisation of a service, not its discriminatory delivery by the state.

\section{Non-discrimination in the Polish Constitutional Law}

In the Polish constitutional law, the right to equality is guaranteed in Articles 32 and 33 of the Polish Constitution.

Art. 32.

\footnotetext{
${ }^{345}$ GC 28, supra note 153 , para. 3.

346 Abdulaziz, supra note 304.

${ }^{347}$ Supra note 323.

${ }^{3+8}$ Singh Binder, supra note 315.

399 Eldridge, supra note 327.

${ }^{350}$ Law, supra note 290 at 1012.
} 
1. Everybody is equal before the law. Everybody has the right to equal treatment by the public officials.

2. Nobody can be discriminated against for any reasons in the political, social or economic life.

Art. 33.

I. Women and men in the Republic of Poland have equal rights in the family, political, social and economic life.

2. Women and men have. in particular, equal rights to education, employment, advancement. equal right to pay for work of equal value, to social security. as well as to the [public posts. functions, etc.]. ${ }^{351}$

In the jurisprudence of the Constitutional Tribunal, this right is understood to encompass two basic requirements. The first is a procedural and formal equality imposed by the formulation of equality before the law and is understood as equal application of existing law. ${ }^{352}$ According to the second meaning, the equality in law, the right is understood as substantive equality. In one of its judgements, the Polish Constitutional Tribunal expressed this conception as: the "requirement of such shaping of the provisions of the law that all consequences of the principle of equality are taken into account. ${ }^{.353}$ This formulation allows a wide interpretation of what state actions or state omission constitute discrimination. In this judgement, the Constitutional Tribunal also reaffirmed the principle that the right to equality is closely linked to the principle of social justice. which can give guidance regarding the criteria that can be used by the legislator to introduce certain distinctions in the law. ${ }^{354}$ Indeed, the Constitutional Tribunal pointed in this judgement to the fact that "[i]n the existing social order there is the special need to establish special guarantees for the achievement of the equality for women." ${ }^{355}$ In support of this, the Tribunal referred to Art.78 of the previous Constitution $1952^{356}$ and pointed to the fact that it is women, who are the real

\footnotetext{
351 Constirution, supra note 120, Art. 32 and 33.

${ }^{352}$ See e.g. Judgement of Constitutional Tribunal (CT) of 17 September 1988, U 7/87, 1988 OTK 14. See also Judgement of CT of 17 December 1991, U 2/91, 1991 OTK 149. See also Judgement of CT of 6 April 1993, K 7/92, 1993 OTK 75. See also CT Judgment K 15/97, OTK Z.U. Nr 3-4/1997 poz.37. See also M. Brzezinski, The Struggle for Constitutionalism in Poland (Basingstoke, Hampshire: Macmillan in Association with St. Antony's College, Oxford, 1998) at 172.

${ }^{353}$ CT Judgment K 15/97, online - in Polish - Polish Constitutional Tribunal's webpage: $<$ http://www.trybunal.gov.pl>, (date accessed September 21, 2000); cited in Brzezinski, ibid.

${ }^{354} \mathrm{Ibid}$. The Tribunal has invoked its earlier indications on this point in its Judgment of 28 November $1995, \mathrm{~K}$ 17/95 OTK 1995, part II at 183. The principle of social justice is embraced in the new Polish Constitution in Art.2, supra note 120.

${ }_{355}$ Judgment K 15/97, supra note 353.

${ }^{356}$ Constitution 1952, supra note 126.
} 
subject of the guarantees provided by this article. The equivalent of Art.78 in the present Constitution is Art. 33. The latter is more balanced in talking about equality of men and women, and having both sexes as the subject of the guarantees. The decision of the Tribunal was made after the text of the new Constitution was approved in a 1997 national referendum. Since the Tribunal did not refer to this change in formulation, it may be that the Tribunal did not view its thrust and purpose differently than Art.78. This interpretation is particularly rational, since the situation of Polish women upon the enactment of the new Constitution is not radically improved from before its enactment; thus; the need for a special protection has not ceased to exist. Also. a general guarantee of equality is embraced in Art.32. The historic rationale for the introduction of separate guarantees pertaining to equality between sexes has been the need for the improvement of the status of women in the society. ${ }^{337}$ If the legislature decides that there is still a need to maintain a separate set of regulation pertaining specifically to the issue of equality between women and men. this can be viewed as confirmation of a continuing need for special attention to efforts to improve the status of women.

The need for special guarantees for women, as the Constitutional Tribunal states. is based on women's particular biological and family circumstances. These circumstances justify legal measures to give special benefits to women, if the purpose of them is to provide substantive equality. ${ }^{358}$ The principle of social justice can require the law to specifically address the issue of the disadvantaged social position of women, and to guarantee them equal opportunities with men. These requirements were discussed by the Constitutional Tribunal in the case concerning the age of retirement for civil servants, which was established differently for women (60 years)

Art. 78. I. A woman in Poland has equal with man rights in all areas of public, political. economic, social and cultural life.

2. To this point, a guarantee of woman's equality are:

1) equal with man right to work, equal pay for equal work, ..., right to social security, education, honorary titles and access to education;

2) protection of a mother and a child, protection of a pregnant woman, paid maternity leave, state's obligation to develop ... childcare facilities, ....

3. Poland will strengthen the position of women in society, in particular mothers and women working professionally.

${ }^{357}$ Judgment K 15/97, supra note 353 .

338 Judgement of Constitutional Tribunal of 24 October 1989, K 6/89, OTK 1989 at 100. 
and men (65 years). ${ }^{399}$ The Tribunal distinguished in this case two issues requiring separate resolution: first, the question of the general "privilege" ${ }^{\text {360 }}$ for women by making it possible for them to retire earlier; and, second, the regulation of civil service employment which allowed the state to dismiss an employee without their consent, when they reach the age of retirement. Hence. the legislation made it possible to dismiss a female civil servant without her consent when she reached the aye of 60 , while men had a guarantce that. unless there werc other reasons for it, they could not be dismissed until they reached the age of 65 . This aspect of the law was found to be discriminatory and not justified by other constitutional, public interests. However, the Tribunal found that the first regulation - designed to permit women to retire earlier - was justified because of the need for the special protection of women. resulting from their weaker position in the society, due to biological and social circumstances. ${ }^{361}$ The question, in the case regarding the retirement age. concerned the justification for the already existing privileging of women. It has been found to be an "equalising privileging." The Tribunal also stated that such privileging might be required, but with regard to. for instance. jobs. in which the biological and social differences are particularly visible and significant - such as mining jobs. ${ }^{362}$ Also, this particular "privilege" for women - the earlier retirement age - is the "tradition" of the Polish labour law. For this reason, any attempt to remove it, can be pronounced not permissible as violating the guarantee of the rights once acquired (the principle of stability in law). ${ }^{363}$ These particular circumstances of the case, result in that it is not possible to make a more general conclusion concerning the fact whether the special protective measures could be required by law, although, on the basis of this case, such possibility should definitely not be excluded. What is significant in this case for the question of the criminalisation of sterilisation, is the suggestion that the state can be legally obliged to ensure women equal opportunities in professional and public life. If so, it may support

\footnotetext{
359 Judgment 15/97, supra note 353.

${ }^{300}$ The value of this privilege has been recently questioned by some authors, after the reform of the pension system has taken place. In the reform, the principle that pension is contingent upon the number of years of employment has been introduced. The critics pointed out to the fact that when a person reaches the retirement age (lower for women), her employment security is usually weakened.

${ }^{361}$ See supra note 359 and accompanying text.

362 Judgment K 6/89, supra note 358.

${ }^{363}$ Judgment $15 / 97$, supra note 353.
} 
the argument that these guarantees require elimination of criminal barriers to comprehensive access to reproductive and contraceptive services.

The jurisprudence of the Polish Constitutional Tribunal on the right to equality suggests that the path to argue the adverse effect discrimination resulting from the criminalisation of sterilisation, under the provisions of the Polish Constitution, cannot be said to be closed. One more factor that could support such view is the fact that increasingly, the Constitutional Tribunal, in its judgements concerning the issue of equality between men and women, refers to the international human rights provisions, ${ }^{364}$ which. as it was argued above, allow to interpret them as encompassing this category of discrimination.

\section{Conclusion on Equality}

I have argued in this section that the criminal ban on sterilisation has a disproportionate adverse and discriminatory impact on women. which could amount to the violation of the right to equality between women and men.

It has been pointed out that, although the benefits of the prevention of unwanted pregnancies are usually shared by both women and men. it cannot be said that the burden of such pregnancy is fully equally shared by both sexes. This results both from biological differences between the sexes, as well as from social expectations from the role of the mother. The emphasis of this section on burdens of pregnancy and child-bearing does not imply that the experience of pregnancy is an objectively negative and burdensome experience. Women might welcome and appreciate pregnancy and enjoy also the double amount of work, or other consequences of the pregnancy. However, in many cases, unwanted pregnancy still deprives women of opportunities of social and economic opportunities available to men.

The law by itself does not create the disadvantaged position of women. This position is caused by, as indicated above, biological differences and society's norms. However, the law does not allow women and their partners to take advantage of comprehensive contraceptive option,

\footnotetext{
${ }^{364}$ Ibid. The Tribunal refers to, among others: Charter of the United Nations, 26 June 1945, Can. T.S. 1945 No. 7, Art. 55 c; Economic Covenant, supra note 133, Art. 7; and European Comvention, supra note 131, Art. 14. See also Judgment of CT of 28 March 2000, K 27/99, online: Constitutional Tribunal's Webpage, supra note 353.
} 
including sterilisation, which could alleviate this disadvantage and could put women on the more equal footing with men as far as their life opportunities are concerned.

Anti-sterilisation law is an example of the complicated case of indirect and adverse affect discrimination. In the jurisprudence of the European Court of Human Rights indirect discrimination has been only recently explicitly held as the violation the right to equality as guaranteed in international law in the case of Thlimmenos. Earlier cases where it has heen considered: Abdulaziz before the European Court and Singh Binder before the Human Rights Committee did not allow to conclude that this category of discrimination is not embraced by the international human rights provisions. Arguing this sort of discrimination. in the case of sterilisation would, however, require overcoming some conceptual difficulties, such as accommodating the fact that the law. in this case does not distinguish between the groups of people. by treating them differently. but distinguishes between the categories of services. by criminalising a service which can benefit women and put them on the more equal footing with men.

Some aspects of the decisions of Polish Constitutional Tribunal in the cases concerning the right to equality, such as: the emphasis on the factual - biological and social differences between women and men, ${ }^{365}$ the need for the special focus on the situation of women and taking into account these differences which might impede their equality in the society, ${ }^{366}$ the "potential" requirement, and not only permission, that the law address this problem by awarding women with special protection, ${ }^{367}$ as well as, the obligation to examine cautiously the way the particular legal provision contributes to the elimination of the factual inequalities in social life, ${ }^{368}$ suggest that the path to find the anti-sterilisation law to be the violation of the right to equality guaranteed in the Polish Constitution, cannot be said to be closed.

Establishing that the criminalisation of sterilisation is discriminatory, is only the first step of the verification whether the law constitutes the violation of the right to equality. This

\footnotetext{
${ }^{365}$ See text accompanying note $\mathbf{3} 58$ and 361 .

${ }^{360}$ See text accompanying note 355 .

${ }^{367}$ See text accompanying note 362 .

${ }^{368}$ See e.g. Judgment K 15/97, supra note 353.
} 
verification requires, as it has been established originally in the Belgian Linguistics Case, two subsequent steps: examination of the justification given by the state for such regulation and looking at the proportionality between the impact of the regulation on the lives of individuals and the public interest submitted as its justification. ${ }^{369}$ This are the same steps that have been pointed out in the case of alleged violation of the right to respect for private and family life. The analysis of the concerns which could be submitted as justifying the alleged violation and the weighing of harms of the restriction and harms of the liberalisation will take place in Chapter IV.

${ }^{369}$ See also Inze v. Austria (1987), App. No. 8695/79, 126 Eur. CL. H. R. (Ser. A), 10 E.H.R.R. 394. The Court submits in para. 41: "For the purpose of Art. 14, a difference of treatment is discriminatory if it "has no objective and reasonable justification', that is it does not pursue a 'legitimate aim' or if there is not a 'reasonable relationship of proportionality between the means employed and the aim sought to be realised." 


\section{PART E. Conclusion}

In this chapter I have been analysing whether provisions of international human rights treaties can protect the harms of anti-sterilisation law identified in Chapter two and give support in challenging the law.

I Part B of this chapter I have analysed whether the violation of the right to health could be invoked with regard to health interests infringed by the anti-sterilisation law. It has been identified in this chapter that the evolving concept of health in international law encompasses sexual and reproductive health, psychological and social well-being. However, it has been also concluded that there is not yet sufficient support in the existing international and national jurisprudence to make the violation of the right to health the strongest argument in the challenge to anti-sterilisation law. There still needs to be more normative and jurisprudential development in this sphere.

Furthermore, I have turned to two classical rights - right to respect for private and family life (Part C) and the right to equality (Part D). I have argued that the harms of the lack of access to sterilisation can be regarded as falling within the scope of interests protected by these rights and that an argument could be made under the European Convention and the Political Covenants that anti-sterilisation law results in the interference with the provisions of these treaties.

However, also in Part C I have pointed to the fact that before being able to hold the state accountable for the interference with these two rights, it is necessary to consider the potential justifications that the state can advance to demonstrate that the anti-sterilisation law is necessary to protect certain concerns associated with the use of sterilisation as contraceptive method. The final section of Part $\mathrm{C}$ has identified principles or guidelines, according to which the verification of justifications of the anti-sterilisation needs to be conducted. Although these guidelines were discussed in the association with the right to private and family life, they were not based solely on case law concerning this right, but concerned general principles that apply also to the alleged violation to the right to equality. Although the provisions on the right to equality do not specify the enumerated grounds which could justify the state's action interfering with this right, nevertheless the practice of the European Court of Human Rights demonstrates that these will be, 
in most cases, analogous to those specified with the right to respect for private and family life. ${ }^{370}$ Also, similar rules will apply in both cases to the way the scrutiny of these justification will be conducted by the international supervisory organs. The last section of Part $\mathrm{C}$ identified a number of principles of the scrutiny of the potential justifications. The most prominent of them will be recalled below. First of all, the state in pursuing any justification needs to demonstrate that antisterilisation law is "nccessary in a democratic society" for the achievement of a legitimate aim. The state has certain margin of appreciation in arguing this necessity. However, the arguments forwarded by the government are scrutinised by the supervisory organs taking into consideration the development of the European consensus on this matter. The supervisory organs will also conduct a proportionality test - weighing the harms imposed by the measure, on the one hand. and the interests which the state claims to protect through this measure. on the other. The factors that the courts will take into consideration in assessing the proportionality of the restriction are: its effectiveness; the breadth of its implications, the existence of the enforcement of the measure: the feasibility of other, less restrictive means to achieve the stated goals; and its potential differential effect on various groups of the society. The analysis of the justifications will be made in Chapter four.

${ }^{370}$ There are no explicit and enumerative grounds for justification of government's intervention in the right of equality. However, in practice, the government pursue grounds that mirror those mentioned in Article 8 . See Livingstone, supra note 313 at 32 . 


\section{CHAPTER IV.}

\section{JUSTIFICATIONS OF ANTI-STERILISATION LAW IN POLAND}

\section{PART A. Introduction}

In Chapter three I discussed the human rights provisions, which could be invoked to protect individuals and society from the harms imposed by the anti-sterilisation law. In concluding this chapter, I have pointed the next step of such analysis - the considerations of justifications, which the state can advance to safeguard the impugned legislation from such legal challenge.

In chapter two, besides the harms of anti-sterilisation law. I have also identified various concerns or reasons underlying the potential apprehension and resistance towards making sterilisation accessible for the purposes of family planning. This review in Part C. Chapter two should help me to consider as to what grounds could the state propound to justify the existing restriction and interference. The concerns identified there where grouped into two main categories: macro-concerns and micro-concerns.

In Part B of this chapter I want to discuss the first of the macro-concerns - a "demographic" concern: influenced by the worry about the decline of birth rate and the ageing of the population and making a link between sterilisation and potential impact of its popularisation on the process. I want to first talk about the sources of such concern - the demographic situation of Poland. This situation has prompted Polish government to accept "Pro-family Policy" - a policy document, which, as one of its goals states the restraining of the decline of birth-rates in Poland. I discuss this document and measures proposed to achieve its demographic objective. The goal of such analysis is to outline the pronatalist atmosphere in Poland and to identify potential links with the policy towards sterilisation. It should also assist us in identifying various measures which could be used to achieve demographic goals and principles on which such policies should be based. Thus, I look at the demographic policy of Poland through the perspective of principles, upon which the population policy of any country should be based, 
principles developed by demographic experts and international community. The final step in this part is to analyse whether sterilisation could be justified by the state as a measure which is necessary as an element of the national demographic policy.

In Part C I consider the second macro-concern - "moral" concerns. I analyse whether it is legitimate to propose that the use of this procedure is not consistent with the value system of the Polish society. I turn to potential sources of such a view. The first source, which needs to be taken into account is the condemnation of sterilisation by the Roman Catholic church. It is thus, necessary to look at the meaning of this condemnation for the society and its implications for the question of a legal status of this procedure. Furthermore, other societal values or moral norms. which could potentially be infringed by legalising contraceptive sterilisation are discussed. These include "family values" and the ascription of a special value to the ability to procreate or the sexual identity of a woman in the Polish society. Finally, I turn to fundamental questions: whether the criminal ban on sterilisation is necessary in a democratic and pluralistic society, whether such ban is proportional to the harms imposed by such restriction as well as whether it constitutes the least restrictive mean to achieve the goal of protection of the society's values, moral norms or national identity.

Micro-concerns will be analysed in Part D of this chapter. To recapitulate, microconcerns arise from the opinion that individuals need to be protected from negative consequences of the sterilisation operation and that the way to give this protection is by criminally prescribing this method. I identify these implied negative features or consequences of this method as well as recall its potential social and health benefits discussed in Chapter II, Part B. The most important feature of sterilisation is its irreversibility, which means that the post-sterilisation regret is a serious concern. Also, another concern is the potential for an abuse of this method or coercion, pressure on its recipients. There are three basic questions asked in this part. First, what is the result of weighing advantages and disadvantages of this method? Second, is it possible to protect interests of individuals through means other than criminal proscription? And third, if there are other means feasible - is the criminal ban necessary in a democratic state and are its effects not more harmful than the implied harms of sterilisation? 
The European Convention in Art. 8 (2) identifies following grounds for justification of the permitted interference with the right respect for private and family life: the protection of public safety, the protection of the economic well-being of the country, the prevention of disorder or crime, the protection of health, the protection of morals or the protection of the rights and freedoms of others. The three groups of concerns which will be discussed in this chapter fall into four of these categorics. As suggested by Commissioner Fawcett. in his dissenting opinion in the case of Brügemann, ${ }^{371}$ the "demographic" concern could prompt the government to justify the restriction on the ground of the protection of the economic well-being of the country. ${ }^{372}$ The "moral" concerns would obviously be seen as requiring the protection under the ground of the protection of morals. Finally, the micro-concerns fall into two categories - the protection of health ${ }^{373}$ and. more generally - the protection of the rights of others. It must be emphasised. however. that the rights of others are understood here as denoting rights of individuals and as encompassing also the interests of the persons wishing to be sterilised themselves.

This chapter should allow me to conclude whether the potential harms, concerns associated with the decriminalisation of sterilisation could justify the restriction of the right to privacy and the right to equality, and thus, whether there are sufficient grounds for claiming that the proscription of sterilisation in the Polish legal system should be maintained.

\footnotetext{
${ }^{371}$ Brügemann II, supra note 183.

37. lbid. para. 4 at 256.

${ }^{373}$ Although the way Article 8(2) is formulated could suggest that "protection of health or morals" should be treated as a unitary concept, these two grounds have been considered separately in the jurisprudence of the Commission and Court.
} 


\section{PART B. Protection of the Economic Well-being}

[P]opulation decline ...has evoked fear, confusion, and misunderstanding among a broad community of politicians, scientists, churchmen, and novelists in many different countries. ${ }^{374}$

As indicated earlier in this work, in 1999 - for the first time since World War II - Poland experienced a negative birth rate. ${ }^{375}$ Similar to some other European countries, the fertility rate in Poland has fallen. in recent years, below the generation-replacement level. ${ }^{376}$ This demographic trend will lead to a higher proportion of the population being aged. The significance of this trend has been noted by demographers and international population scholars. ${ }^{377}$ The most important concerns to which these specialists draw attention are the implications of this process for pension. housing, education. health care and social services. ${ }^{378}$ In all these spheres this trend could potentially have a negative influence on the national economy.

In this light, sterilisation may take on more importance. Sterilisation. as discussed several times in this work is a practically permanent contraceptive method, although the rates of reversals have been increasing. For this reason, it has been suggested, albeit with little empirical

\footnotetext{
${ }^{374}$ M.S. Teitelbaum \& J.M. Winter, The Fear of Population Decline (Orlando, Fl: Academic Press. 1985) at 129.

${ }^{375}$ See supra note 119 and accompanying text.

376 "European Birth Rates Reach All-time Lows" (1999) 7 Reproductive Health Matters 162. For Poland - fertility rates have been below replacement level since 1989. In 1997 average number of children born by a woman of reproductive age (15-49 years) has been estimated at 1,43 (approximately same as for the rest of Europe). This information comes from "Program Polityka Prorodzinna Panstwa" (National Pro-family Policy) Druk Sejmowy $\mathrm{Nr}$ 1522, the document accepted by the Polish Government on 3 November 1999, published by: Biuro Kancelarii Sejmu, online: Sejm Rzeczypospolitej Polskiej (Lower Chamber (Sejm) of the Parliament of the Polish Republic) Wepage: <http:/www.sejm.gov.pl; the data-base, containing the document: <http://orka.sejm.gov.p/Rejestrd.nsf>, (date accessed: September 21, 2000) [hereinafter: "Pro-family Policy"].

${ }^{3 \pi}$ See e.g. Population Division Department of Economic and Social Affairs UN Secretariat, "Replacement Migration: Is it A Solution to Declining and Ageing Populations?" ESA/P/WP/160, 21 March 2000 (New York: UN Department of Economic and Social Affairs - Population Division, 2000), online: United Nations Population site $<$ http:/www.un.org/esa/population/migration.htm> (date accessed: September 21, 2000) [hereinafter: "Solution to Declining Population"]. See also Report of the Secretary General "Twenty-first special Session of the General Assembly for an overall review and appraisal of the implementation of the Programme of Action of the International Conference on Population and Development", A/54/442, para. 23. In this report the Secretary General refers to the document "Key actions for the further implementation of the Programme of Action of the International Conference on Population and Development (AS-2 1/5/Add.1)", an integral part of "Cairo Plus Five", supra note 342. He states that "Cairo Plus Five" "recogni[s]ed the implications of changing age structure and the ageing of the population ...".
} 
research to date, that if sterilisation was more popular and accessible, it could influence population trends. ${ }^{379}$ Not many studies have been conducted on the actual relationship between the popularity of sterilisation as a contraceptive method and birth rates. And, even taking into account the studies that have been conducted. it is not my intention to assess or compare the scientific value of such findings. Rather. I would like to point to some academic commentary on this point. Dorothy Nortman in her monograph on "Stcrilisation and Birth Rate" wrote:

On a priori grounds it can be argued that the net demographic impact of sterilisation is likely to be small because couples sufficiently motivated to resort to so certain a method would surely practice some other efficient method if they could not be sterilised. The experience of developed countries. where low births were achieved long before sterili[s]ation became available or popular. supports this proposition. ${ }^{380}$

Sterilisation is usually chosen by married couples who already have two or three children and do not want to have any more at least in the near future. If denied access to sterilisation. they will attempt to use all other possible methods to prevent child-bearing. ${ }^{581}$ Thus. it may be suggested that the impact of sterilisation on the birth rate should not be overestimated as a threat to population size. Even if its actual impact is insignificant, however. we should still accept that a potential link exists between the use of sterilisation and fertility rates.

The remaining question to be resolved is whether the government could argue that if sterilisation became popular, it would accelerate the decline of the birth rate, and, for this reason, it is necessary to retain the ban on the use of this method. The Polish government could argue that the retention of the ban on sterilisation is necessary to slow the declining birth rate and as part of "population policy" to steer the demographic situation.

Under a broader vision of population policy, however, the line between means and ends is less clear. "Population policy" is most commonly associated with a:

"formal statement by government of perceived demographic problems and desired policy goals and objectives ... in order to bring demographic processes in balance with national development goals." 382

373 "Solution to Declining Population", ibid. See also Teitelbaum \& Winter, supra note 374 at 136.

${ }^{379}$ See supra note 118 and accompanying text.

${ }^{380}$ D.L. Nortman, Sterilization and Birth Rate (New York: Population Council, 1980) at 31.

${ }^{381}$ See for example R.P. Petchesky, Abortion and Woman's Choice: The State. Sexuality and Reproductive Freedom, rev. ed. (Boston: The Northeastern University Press, 1990) at 178.

${ }^{382}$ Dixon-Mueller, supra note 78 at 5. 
We can refer to this as a narrow understanding of a population policy. However, a lot of states do not have a formally stated, explicitly formulated population or demographic policy. Rather, they have various social policies "pursued by government for unrelated ends, which may, however, have demographic consequences." ${ }^{383}$ Such social policies, even if not included in a specific document devoted solely to the demographic policy of the state. can be considered as the "population policy" of a state, if they are intended to influence the demographic situation of the state. ${ }^{38+}$ This is a broader understanding of "population policy."

Population policies of states, either pronatalist or antinatalist. have been the subject of interest of international community. Initially, interest was prompted by the concerns over the issue of global overpopulation and its consequences. Subsequently, interest turned to the legitimacy of means that governments employ as part of population policies. The first major international document which concerned population policies was the 1974 World Population Plan of Action (WPPA) drafted during the World Population Conference in Bucharest. This consensus document contains the principle that "[t]he formulation and implementation of population policies is the sovereign right of each nation. ${ }^{-385}$ However, this does not mean that states have unrestricted freedom in shaping their policies concerning population growth. The WPPA and subsequent documents devoted to issues of population and development contain recommendations as to what criteria should population policies fulfil in order to be considered as legitimate for the state to pursue. These documents include: Recommendations for the Further Implementation of the Plan of Action adopted at the 1984 International Conference on Population at Mexico City, ${ }^{386}$ the Cairo Programme of Action ${ }^{387}$ and the "Cairo Plus Five." ${ }^{388}$ The first recommendation is contained in the WPPA itself. Paragraph 14 (a) of the Plan reads:

\footnotetext{
${ }^{383}$ M. Kozakiewicz "The Terminology of Planned Parenthood" in P. Meredith \& L. Thomas, eds., Planned Parenthood in Europe: A Human Rights Perspective (London: Croom Helm, 1986) 13 at 14.

${ }^{384}$ Kozakiewicz, ibid. at 14-15.

${ }^{385}$ United Nations, Report of the United Nations World Population Conference, Bucharest, 19-30 August 1974. E/CONF.60/19 (New York: United Nations, 1995) Part B, para. 14 [hereinafter: "World Population"]

${ }^{386}$ United Nations, Report of the International Conference on Population, Mexico City, 6-14 August 1984 (United Nations publication, Sales No. E.84.XIII.8 and corrigenda).

387 "Cairo Programme”, supra note 105.

388 "Cairo Plus Five", supra note 342.
} 
The principle aim of social, economic and cultural development, of which population goals and policies are integral parts, is to improve levels of living and the quality of life of the people. ${ }^{339}$

Policies cannot, for instance, serve some abstract "impersonal economic objective" ${ }^{" 390}$ or political goals. ${ }^{31}$ The only legitimate goal of the population policies can be to improve the well-being of the citizens. ${ }^{392}$ The state needs to demonstrate how the methods which the government intends to pursue as part of its explicit or implicit population policies, are to influence the well-being of its citizens. The reason for giving the particular emphasis to this last requirement of having the government demonstrate a link between the three factors: the method, the state's policy and the well-being of its citizens; is that, as it has been observed by some authors. concerns over population decline are too often influenced partly by ideology. ${ }^{393}$ In Poland. ideological. nationalistic arguments in favour of building a strong and large Polish nation. as noticed by Andrzej Kulczycki, are likely to arise because of specific historical circumstances. The preservation of the Polish identity during the years of occupation by Russia, Prussia (Germany) and Austria (1795-1918). and the later re-emergence of the Polish state has depended on the survival of Polish nationals. ${ }^{394}$ Arguments invoking the demographic threats to the existence of the Polish nation can be picked up to justify more stringent population policy measures. However, according to the international consensus, such ideological arguments cannot legitimise intrusive pronatalist measures.

Another recommendation of international documents is the need for population policies to respect human rights. ${ }^{395}$ In international consensus documents concerning population and development, references to principles of respect for human rights in population policies are

\footnotetext{
389 "World Population", supra note 385, Part B, para. 14 (a). See also: "Cairo Programme", supra note 105, Principle 5: "Population-related goals and policies are integral parts of cultural, economic and social development. the principal aim of which is to improve the quality of life of all people."

${ }^{390} \mathrm{~S}$. Anand "Population, Well-being and Freedom" in Populations Policies Reconsidered, supra note 102, 75 at 75.

391 See also: P. Abrams, "Reservations About Women: Population Policy and Reproductive Rights" (1996) 29 Cornell Int'l L.J. I at 8. Abrams writes: "Historically, large population were perceived as a necessary component of economic and political strength." Such requirement cannot be valid at present times.

392 Dixon - Mueller, supra note 78 at 197.

${ }^{393}$ See e.g. Teitelbaum \& Winter, supra note 374 at 131 . See also Dixon - Mueller, ibid. at X (Introduction).

${ }^{394}$ Kulczycki, supra note 108 at 487.

${ }^{395}$ Abrams, supra note 391 at 1.
} 
numerous. Some examples include paragraph 14 (d) of the WPPA ${ }^{396}$ and the preamble to the second chapter of the Cairo Programme of Action, entitled Principles. ${ }^{397}$

These two principles - well-being and respect for human rights - are pronounced as underlying values of the policy document "Polityka Prorodzinna Panstwa" accepted by the Polish government on 3 November 1999. Two other principles stated in this document arc: affirmation of the value of the family and the principle of the subsidiarity of the state. ${ }^{399}$ While the document does not constitute the population policy in the narrow sense, it does aim to restrain the negative trends in demographic development. ${ }^{400}$ Additionally, concerns over the falling birth-rate are discussed in the document. ${ }^{401}$ And. finally. the changing demographic situation in Poland is accounted as one of eleven directions of activities of the Pro-family Policy. ${ }^{402}$ These factors allow us to regard the Pro-family Policy as the population policy in the broader sense. Thus, we should look at this policy both from the point of view of its consistency with international population policy as well as its implications for sterilisation policy.

After only a cursory reading of the Pro-family Policy, its pronatalist character can be identified. The tone of discussion and emphasis on negative demographic trends reflects a strong uncertainty and apprehension related to falling birth rates. ${ }^{.03}$ The document does not, however. make explicit the precise harms flowing from declining birth rates. This should constitute the next step after acknowledging the fact that the decline of birth rates is taking place in Poland, and, before proposing any policies to remedy the situation. ${ }^{\text {tot }}$ The document talks about the consequences of demographic changes only in very general and inconclusive terms, which does not permit a proper evaluation of their validity, nor of the rationality of the means chosen to

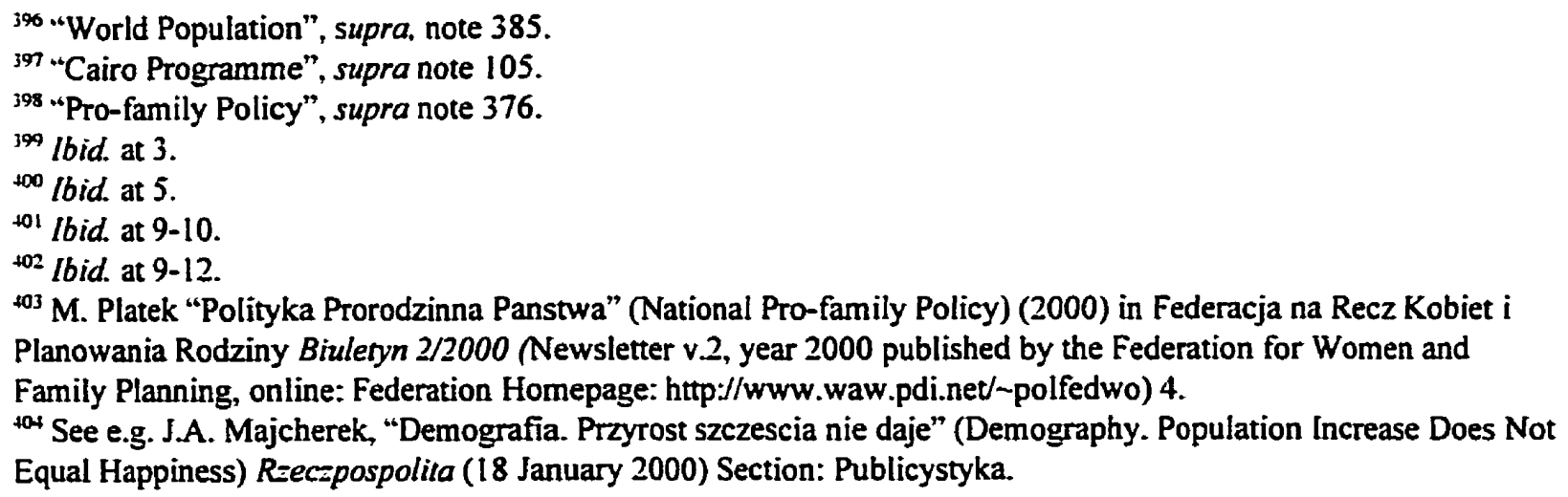


address the problem. The document talks only about the fact that population growth is a guarantee for the stability of economic development, and that demographic fluctuations necessitate constant adaptation. ${ }^{405}$ However, it does not talk about what exact adaptations these changes to the volume and profile of population necessitate. Without spelling out these concerns. it is difficult to evaluate whether the means proposed in the policy constitute the best of a range of uptions or the only possible option to aver the harm flowing from a decline in population. The fact of the decline in population is not inherently a negative process from the point of view of the well-being of the citizens of a country. ${ }^{\$ 06}$ It would be necessary to demonstrate the negative consequences of this process in the specific circumstances of Poland. Without doing so. the policy could be exposed to criticism as being misdirected, unnecessary, or based on ideological grounds. As pointed out above, policies based on such abstract grounds can be criticised under the prevailing international consensus.

However, if the need to boost the population is to justify the retention of the ban on sterilisation, or, as a matter of fact, justify any other restrictive measure, it is necessary to provide more evidence of the link between the proposed measures and how they are to influence the well-being of citizens and address specific concerns raised by the decline of birth rates. Furthermore, although the document does enunciate the twin principles: well-being and respect for human rights, some deficiencies of this document can be pointed out in this respect. Finally, the failure to spell out the precise harms of declining birth rates makes it more difficult to discuss the necessity of a given measure, because there is no clear basis for making a comparison between policy choices. As far as the responses to a fear of population decline are concerned, most authors submit that there are at least 4 policy categories available:

(1) measures to limit access to effective fertility control,

(2) measures to increase fertility via incentives,

(3) measures to increase immigration, and

(4) the decision to adapt to demographic change rather than to influence it. ${ }^{+07}$

t05 "Pro-family Policy", supra note 376 at 9.

${ }^{106}$ For countries dealing with the lack of resources, economic difficulties because of the overpopulation, and when the birth rates are very high, the decline of birth rates is viewed as a positive trend.

${ }^{407}$ Teitelbaum \& Winter, supra note 374 at 146. 
The Population Division of the Economic and Social Affairs Department of the United Nations has suggested "replacement migrations" (third category) as a possible solution for declining and ageing populations. It suggested accepting immigrants from less developed and more populated countries to supplement the labour force and to balance the proportion between young and elderly people. ${ }^{108}$ In other literature, suggestions of means belonging to the fourth category have been often made, such as, for instance: restructuring of the pension system, a more flexible pension age, ${ }^{+09}$ enhanced services and care for the elderly. ${ }^{+10}$ and restructuring of educational and health facilities in response to changing population needs. ${ }^{+11}$

The Pro-family Policy falls in the second group - measures to increase fertility via incentives. The incentives proposed in this document can be divided into two groups: economic incentives, and socio-cultural incentives persuading in favour of having more children. The question of the legitimacy of incentives used in population policies has been analysed by many researchers, among them, by Stephen Isaacs. ${ }^{412}$ Isaacs developed a set of five principles which suggest. where applicable. the use of incentives by the government to influence population. Among those, the most relevant for the purposes of this work are:

Principle 2. The people who are subjected to the policy must agree that it is valid.

and:

Principle 3. Measures that are less restrictive of voluntary reproductive choice should be tried and proved ineffective before more restrictive measures are employed. ${ }^{\$ 13}$

These two postulates share the need to look at how the proposed means would affect those who are directly subjected to them, the way those subjected to them perceive and evaluate them, and the need to balance the gains of pursuing a particular policy, on the one hand, and the potential negative effects on those to whom they apply. The latter is the expression of the principle of proportionality of means and aims. Only taking into account all the different choices for

\footnotetext{
08 "Solution to Declining Population", supra note 377.

${ }^{+09}$ See e.g. Majcherek, supra note 404.

${ }^{410}$ See e.g. "Cairo Plus Five", supra note 342, Part B para. 21(c).

${ }^{41}$ See e.g. Teitelbaum \& Winter, supra note 374 at 150.

4'2 S.L. Isaacs, "Incentives, Population Policy and Reproductive Rights: Ethical Issues" (1995) 26 Studies in Family Planning 363.

${ }^{413}$ Ibid. at 365 .
} 
remedying the negative effects of population decline is it possible to determine whether any particular method is necessary, and whether the goal could not be achieved with other means.

As argued earlier, the main burden of pronatalist policies falls inevitably on women, as they are the ones who undergo pregnancy and child-bearing. In addition to that, they are, at least in Poland, held more responsible by society for the up-bringing of children. They usually devote more time and income (if they have independent sources of incoms) to their children. as compared to the time and resources contributed by men. ${ }^{\text {th }}$ Lack of discussion and appreciation of the burden imposed by these pronatalist policies on women was the source of a lot of criticism in Poland. The first example concerns the way the government has planned to facilitate the combination of work and family obligations. To this end, the need for new or more accessible child-care facilities and the promotion of part-time employment were mentioned in the Profamily Policy. However, it was pointed out that the government has not yet guaranteed any financial resources for achieving this goal. ${ }^{415}$ despite the expectation that people will combine work and child-rearing. Another criticism was prompted by a proposed incentive in the form of longer maternity leaves. It was pointed out that this would result in an even more difficult situation regarding employment opportunities for young women. since increased maternity benefits costs may deter employees from hiring them. ${ }^{416}$ Finally, it was pointed out that the sociological, persuasion incentive, in the form of building a climate of respect for a big family, and promoting family values in education, mass media and other institutions places undue emphasis on the value of having children, which undervalues childless families, which should not be ideologically stigmatised or marginalised. ${ }^{417}$

Sterilisation is not mentioned in the Pro-family Policy. The only link to it, although very remote, can be found in the reference made to the 1983 "Charter of the Rights of the Family," prepared by the Holy See. In Article 3 of the Vatican Charter, it is stated that:

\footnotetext{
\$14 See e.g. M. Catley-Carleson, "Population Policies and Reproduction Rights - Always in Conflict?" (1994) 24 Social Change 3.

415 E. Olczyk "Polityka Prorodzinna. Mydlo i powidlo" Rzecspospolita (26 January 2000).

tio See e.g. Platek, supra note 403 at 7.

${ }^{\$ 17}$ See e.g. K. Montgomery "Kobiety Kontra Rzad: Nie Tylko Macierzynstwo" Gazeta Wyborcza (1 May 2000).
} 
the ... right [of the spouses] to ... decide on the spacing of births and the number of children to be borm ... [should be exercised] in accordance with the objective moral order which excludes recourse to contraception, sterili[s]ation and abortion. ${ }^{418}$

The Pro-family policy declares that the government will take to promote the adoption on the international forum of a new document to enhance the protection of the rights of a family. ${ }^{+19}$ This document would compile the guarantees of family rights provided in provisions of various international documents. An inspiration for this document wouid come, among others, from the "Charter of the Rights of the Family" prepared by the Holy See. This would suggest the commitment of the state to retain the anti-sterilisation law. Interestingly. sterilisation is not mentioned explicitly in the Pro-family Policy itself as part of this explicit pronatalist policy. Indeed, the introduction of anti-sterilisation law cannot be clearly traced to any explicit pronatalist policies of the state at the time of its introduction.

Despite the absence of an explicit reference to sterilisation in pronatalist policy, the Polish government may still claim that retaining of the ban on sterilisation is necessary to prevent negative demographic trends at present. The government could argue that if sterilisation were to become very popular, it would exacerbate the decline of birth rate. and, as this is a real concern for the Polish government. ${ }^{+20}$ the proscription of this contraceptive method should be retained on the basis of protecting the economic well-being of the country. What the government would, in this case, argue is that the criminal ban on sterilisation is necessary to avoid aggravating already negative demographic tendencies, and, for this reason would suffice to justify a breach of the right to privacy or other human rights that where posited earlier. This argument deserves scrutiny.

To justify the retention of the criminalisation of sterilisation, the government would have to demonstrate the following. First, that this measure is necessary in the democratic society for the achievement of the economic well-being of the state, and, second, that the way this measure

\footnotetext{
${ }^{418}$ Charter of the Rights of the Family (Washington, D.C. : United States Catholic Conference, 1983), Art. 3 at 4. ${ }^{219}$ Polish government intends to introduce this project on the forum of the UN Human Rights Committee. 420 "Pro-family Policy", supra note 376 at 5.
} 
interferes with the private life of individuals can be deemed as proportionate to the aim pursued. ${ }^{421}$

Since the matter concerns a significant intrusion in a basic human right, as it was argued in chapter III and the imposing of serious harms pointed out in chapter II, to demonstrate the necessity of this measure, the government would have to prove the link between the measure and the economic well-being in a proportionately greater degree of clarity and persuasion than it has in Pro-family Policy.

First, it is not possible to automatically link the legality and accessibility to sterilisation with the impact on birth rates. This link has been questioned in some studies, because this method is primarily used by those couples that would not have more children even if they did not have access to this method. Furthermore. if the government could substantiate a link between sterilisation and low birth rates, the government would still have to demonstrate the negative effects of the falling birth-rates on the economy of Poland. This link cannot be made simply by pointing to the ageing of the population without further explication of the precise nature of harm. The government would have to be able to indicate particular spheres of economy and people's lives that would be influenced by declining birth rates. This cannot be done in the abstract, but has to be based on expert analysis, which would also take into account nondemographic factors such as the changing economy and recent reforms in Poland in the sphere of health care, education and the pension system. By indicating the particular spheres that would be affected by population decline, the government would be forced to consider a wider range of means to address the expected problems, including, as part of this larger milieu of policy options, the ban on sterilisation itself.

The necessity and proportionality of the criminal restriction of sterilisation is in this context questionable from many different perspectives. Currently, no expert recommend antisterilisation laws for addressing declining birth rates and ageing of a population (expert consensus). From a comparative perspective, the "European consensus" over this issue could be

\$21 See the discussion under the heading: "Necessary in democratic society (4) in Chapter III, Part C, above - notes $261-265$ and accompanying text. 
also invoked. As pointed at the beginning of this part, most European countries are experiencing the same problem. However, so far, none of them stated or suggested that it is necessary to ban voluntary sterilisation as a way to control demographic changes. Such a restriction has been previously imposed in communist Romania, as part of its population policy, and it has been unanimously condemned by the international community. ${ }^{+22}$

Furthermore, as compared to the threc other aforcmentioned categories of possible responses to population decline: measures to increase fertility via incentives, measures to increase immigration, and counteracting the effects of the demographic trend. not influencing the trend itself, ${ }^{423}$ sterilisation is a much more restrictive and intrusive method. Thus, as suggested in doctrine by Isaacs by invoking principles, which should govern the state in implementing population policies, the priority should be always given to other methods. less restrictive than sterilisation, unless the have been proved ineffective. ${ }^{124}$

The effectiveness of economic incentives, for instance, bears considering. Economic incentives might be a particularly advisable response, if they are implemented with the intention of responding to people's needs. Decisions about child-bearing should be always left to individuals. The fertility decline in many European countries, and most probably in Poland, ${ }^{425}$ is attributed to the fact that women (themselves or with their partners) want to have fewer children, not only because of the economic situation, but also because they feel they can fulfil their parental roles better by having more time and giving more attention to fewer children. $\$ 26$ However, there are still families that would prefer to have more children, if they were able to support them. For them, economic incentives would be the response to their own preferences and needs.

\footnotetext{
"22 See e.g. Dixon-Mueller, supra note 78 at 19. See also G. Garcia-Moreno \& A. Claro "Challenges from the Women's Health Movement: Women's Rights versus Population Control" in Population Policies Reconsidered, supra note 102,47 at 52 .

13 See supra note 407 and accompanying text.

${ }^{27}+$ See supra note 413 and accompanying text.

${ }^{425}$ P. Eberhardt, "Spoleczenstwo. Malo nas" (Society. Too few of us) Rzeczpospolita (21 December 1999) Section: Publicystyka, Opinie.

${ }^{\$ 26}$ D. Stein, People Who Count: Population and Politics, Women and Children, (London: Earthscan, 1995) at 9. Ibid. at 25.
} 
The criminal restriction of the contraceptive method, on the other hand, can be only viewed as limiting the options for individuals. As such, it constitutes a serious deprivation of rights by infringing the autonomy of individuals regarding child-bearing. Indeed, some have ventured the view that this anti-contraceptive approach forces women into reproductive roles and treats them as means to population and demographic goals rather than as ends in themselves. One commentator expressed it as 'treat[ing] women's bodies as the instruments of male dominated populationist ends." 27

In sum, even if a link is established between contraceptive sterilisation and a decline in birth rates, the current blanket criminal ban on this service in Poland is unnecessarily broad to achieve the stated goals. It may be argued that it is sufficient to introduce certain limitations on the access to sterilisation based on. for instance. the number of children the person wishing to undergo sterilisation already has. This also constitutes interference with the right to privacy but is not as intrusive as the total proscription. ${ }^{428}$ Such limits are being used in other countries. ${ }^{+29}$ although they might be also inspired by different motives. such as the issue of securing informed consent and precautions against post-sterilisation regret. Nevertheless. the fact that it would be possible to limit access to sterilisation without totally banning it supports the thesis that this restriction is too broad and, thus, not proportionate.

\footnotetext{
${ }^{427}$ M. Karkal "Family Planning and the Reproductive Rights of Women" in L. Lingam, ed.. Understanding Women's Health Issues: A Reader (1998) online: Global Reproductive Health Forum Webpage $<$ http:/www.hsph.harvard.edu/grhf $>$; the article, in the Research Library <http:/www.hsph.harvard.edu/grhf/SAsia/suchana/0804/rh346.html> (date accessed: September 21, 2000). ${ }^{428}$ It is important to note at this point that this category of restrictions of access to sterilisation has been found controversial and has been criticised in contemporary literature - see e.g. "International Protection", supra note 171 at 649 . Such requirements, as Cook discusses, are clearly discriminatory if they apply for instance only to women and not to men. If they apply in the same way to both genders, the issue is more complicated. For further discussion of this issue, see conclusion of this chapter - Chapter IV, Part E., below.

${ }^{\$ 29}$ Some examples of such regulations: Age limit, for instance - Sweden - sterilisation for contraceptive reasons is permitted if 25 years or older - The Law on Sterilisation of 12 June 1975 (Svensk Forfattnignssamling 1975:580) cited in ARPL, 1975. (Medford, Mass: Tufts University, 1976) at 15 . In Finland sterilisation may be performed if a person already has three children and is 30 years old or older. The only exception regards a person for whom any other method of sterilisation would be unsuccessful, see - Law No. 125 amending the Law on sterilisation, 31 January 1985 (Finlands Författningssamling, Nos. 123-126, 7 February 1985, p.262, translated in (1985) 36 (4) IDHL 978. In Hungary, contraceptive sterilisation is available only to those 35 or over, or who have at least three children - Art. 187 of The Public Health Care Act and Welfare Ministry Order No. 25/1998 (VI. 17) - cited in Center for Reproductive Law and Policy (CRLP), Women of the World: Central and Eastern Europe, forthcoming (New York, NY: CRLP, 2000).
} 
Another factor to consider in the proportionality analysis is the prevalence of and danger of underground sterilisation. Similarly to abortion, abolition of sterilisation does not mean it is not being performed. Abolition, rightly or wrongly, results in illegally performed services, which are harder to access and are much more expensive. By having such legal situation, the state loses control over the quality of the services, and cannot take any precautions for prevention of modical risk that unsafe sterilisation could potentially bring about. This diminishes the effectiveness of criminal laws as a population policy tool. and exacerbates the harm occasioned by the infringement of privacy rights. Furthermore. the ban will disproportionately affect lowerincome group of the society, because they will not afford time and resources necessary for the search of doctor willing to perform illegal sterilisation.

The foregoing analysis is admittedly cursory, but it suffices to suggest that. even based on these examples. the Polish anti-sterilisation law would be difficult to justify with an intervention in population policy. This law is too intrusive onto the lives and rights of individuals and it is not the least restrictive mean to achieve demographic goals. 


\section{PART C. Protection of Morals}

If the legislator of the member country reasonably decided that certain acts such as interruption of pregnancy must be punishable lest the boundary between right and wrong was violated in the moral conscience of the population and the dangerous conclusion from the absence of sanction to permission was drawn, this had to be respected in the interpretation of the Convention. ${ }^{430}$

\section{Introduction}

Historically, reproductive and sexual health matters were regulated by laws which were influenced by moral concerns ${ }^{431}$ rather than by health concerns or respect for people's privacy. In some countries, contraception and sterilisation were regarded as criminal offences against morality. ${ }^{332}$ They had a reputation for encouraging or supporting promiscuity, licentiousness and irresponsible sexual behaviour. ${ }^{433}$ Typical example of this approach is the well-known dissenting opinion of Lord Denning. who in the case of Bravery v. Bravery. ${ }^{434}$ in the House of Lords, stated:

Take a case where sterilisation operation is done as to enable a man to have the pleasure of sexual intercourse without shouldering the responsibilities attaching to it. The operation then is plainly injurious to the public interest. It is degrading to the man himself. It is injurious to his wife and to any woman to whom he may marry, to say nothing of the way it opens to licentiousness. ... [H]e strikes at the very root of the marriage relationship.... ${ }^{435}$

This opinion is an example of the influence of the conception of sexual morality. which prevailed at the time when the restrictive laws on sterilisation or abortion were introduced. Nevertheless, the conception of sexual morality has not remained static, but undergone a slow but steady evolution. In the overwhelming majority of the countries this evolution, together with

\footnotetext{
${ }^{430}$ Brügemann I, supra note 183 at 113 . (This quote is part on an argument submitted by the government of the Federal Republic of Germany, in support of the justification of restriction on the ground of the protection of morals.)

${ }^{+31}$ R.J. Cook \& B.M. Dickens, Considerations for Formulating Reproductive Health Lans, $2^{\text {nd }}$ ed. (Geneva: World Health Organisation, 2000) at 8 [hereinafter: Considerations].

${ }^{432}$ R.J. Cook, "Gender, Health and Human Rights" in J.M. Mann et al., eds., Health and Human Rights: a reader (New York: Routledge, 1999) 253 at 257.

${ }^{433}$ R.J. Cook, "Contraception and Abortion: Legal Distinctions and Dynamics" in F.K. Beller \& R.F. Weir, eds., The Beginning of Human Life (Dordecht: Kluwer Academic Publishers, 1994) 165 at 167.

${ }^{434}$ Bravery v. Bravery, [1954] 3 All E.R. 59 (H.L.).

${ }^{435}$ Ibid. Denning L.J. at 68 . The decision is obiter dicta in the case which concerned divorce proceedings. Mrs. Bravery was attempting to prove the cruelty of her husband, by claiming, among others, that he underwent a
} 
the influence of other factors, such as health concerns, concerns over respect for human rights or demographic concerns have led to decriminalisation of contraception, and, in many states, to the decriminalisation of abortion and sterilisation.

In Poland, this liberalisation process has not influenced the regulation of sterilisation. For this reason, the question in my work concerns whether it is possible to claim that the retention of the criminalisation of stcrilisation can be justified by the Polish authorities as necessary for the protection of morals. A potential barrier to forwarding a moral justification for the antisterilisation law is that it is classified as an offence against health interests and not morals. The ban on sterilisation for contraceptive purposes is derived from the provision of the criminal code. which constitutes the criminal offence of inflicting health detriment. The offence is listed in the criminal code in the chapter entitled: "Offences against Life and Health". ${ }^{+36}$ The rationale for this category of offences is the protection of health and physical integrity of others. In the case of Laskey, Jaggard \& Brown v. United Kingdom ${ }^{437}$ before the European Court. Judge Loncaides, in a dissenting opinion, reasoned that, the protection of morals can only be invoked as a justification for the restriction if the restriction was genuinely introduced to protect morals, and not as ex post facto justification. ${ }^{+38}$ Given the fact that it is a crime of health, not morals per se, it was enacted as such rather than under "Crimes against Sexual Freedom and Decency". listed in Chapter XXV of the Polish Criminal Code. ${ }^{+39}$ This may give a contemporary moral justification an ex post facto character. Nevertheless, in the case of Dudgeon, ${ }^{+10}$ European Court of Human Rights' approach has been that the relevant factor for the validity of the justification of the restriction on the ground of the protection of morals not only depends on the rationale of the introduction of restriction, but rather on the fact whether "the general aim pursued by the

sterilisation operation after 4 years of their marriage and 2 years after the birth of their first and only child, without her approval, even though she desired to have more children. Her application was dismissed as unjustified. ${ }^{436}$ Criminal Code, supra note 1, Chapter XIX, Art. 148-162.

${ }^{437}$ Laskey, Jaggard \& Brown v. United Kingdom (1997), App. Nos. 21627/93, 21826/93, 21974/93, 24 E.H.R.R. 39.

338 Ibid. para 38 at 57.

${ }^{439}$ Criminal Code, supra note 1, Chapter XXV. It includes, amongst others, following offences: rape, sexual harassment, procurement (crimes against sexual freedom) as well as pornography and incest (crimes against good morals /decency/).

\$0 Dudgeon, supra note 250. 
legislation remains the protection of morals in the sense of moral standards obtaining in the country]" ${ }^{n+1}$ as of the time of proceedings, that is, in the current cultural and political situation in the state. ${ }^{42}$ Thus, it seems that the claim that the retention of the criminal ban on sterilisation is necessary for the protection of morals, regardless of its potential ex post facto character, still bears scrutiny. ${ }^{4+3}$

\section{"Immorality" of Sterilisation}

What is immoral about sterilisation and what are the reasons for claiming that its prohibition is necessary to protect public morals? The least complicated answer would be to say that sterilisation is immoral according to Roman Catholic teaching. The vast majority of Poles are Catholic; thus. they adopt this view. This theory of moral justification for the law, however, is built upon a lot of presumptions. For example: that if something is considered immoral. it must be criminalised and vice versa or, or that if the majority of Poles declare to be Catholics. they necessarily agree with the Church's teaching. It also assumes a certain position and role of the Catholic church in Poland as an authority in moral issues. All these presumptions. are, however. questionable and need to be examined on their merits, cautiously. I will do so by looking at (1) role of the Roman Catholic church in the Polish society, (2) the position of the Catholic church on sterilisation, and (3) the role that the teaching should play with reference to the legislative process.

(1) Role of the Roman Catholic church in the Polish society

Roman Catholics constitute approximately $95 \%$ of the population of Poland. ${ }^{1+4}$ Not all of them are practising Catholics, but they identify themselves with the Catholic religion. The church

$4+1$ lbid. para. 46.

4tz lbid.

${ }^{43}$ An interesting question to consider is what would happen if the protection of health was not held to justify the criminalisation of sterilisation and if it was determined that it is only protection of morals that justifies such restriction. One could argue that legislators should then exclude the sterilisation operation from the general category of offences against health and life and to either move it to a chapter "Crimes against Sexual Freedom and Decency or to create a new, separate category, in which sterilisation would be included.

t4 Survey on religiosity in the Polish society by Centrum Badania Opinii Spolecznej (Centre for Public Opinion Analysis) (CBOS), December 1992, Warsaw; cited in W. Nowicka, "Roman Catholic Fundamentalism Against Women's Reproductive Rights in Poland" (1996) 8 Reproductive Health Matters, [Part 1] and [Part 2]. 
has always played an important role and exercised significant influence over the life of Polish society due mostly to historical circumstances such as the support for sustaining Polish identity during the years of a struggle for independence (1795-1918), and support for and open opposition to the Communist regime in years 1945-1989.

With the collapse of communism in 1989, the Catholic church, which remained powerful (socially, but not politically) during communism, received an opportunity to influence public policy. Many examples demonstrate that the Catholic church's goal since 1989 has been to establish a strong position in the Polish society and also to "conver[ $t]$ Poland to a model Catholic state.... ${ }^{* 45}$ These include involvement in: introduction of the instruction of religion to public schools, insistence on display of religious symbols in public institutions. introduction of a legal requirement of respect for Christian values in Polish media. as well as a campaign to restrict abortion. At the same time. the intensified activities of the church and its influence on public life have inspired some resistance in the society. In a national opinion poll conducted in February 1999. $57 \%$ of the respondents pointed that the church should have less influence on public life than it has been exercising so far. ${ }^{+16}$

(2) The position of the Catholic church on sterilisation

The issue of sterilisation in moral theology appeared at the end of the 19th century, when the technology of surgical sterilisation was discovered and developed. This invention has prompted the Catholic church to consider its moral evaluation. ${ }^{447}$ In the church's teaching, the direct and indirect sterilisation are treated separately. The latter meaning a sterilisation being a non-intended, although often foreseen, side-effect of a necessary treatment. It is fully justified according to the doctrine of double effect, when certain conditions are satisfied. ${ }^{418}$

\footnotetext{
\#s H. Jankowska, "Report of the Reproductive Rights Campaign in Poland" (1993) 16(3) Women's Studies Int'l Forum 291 at 291.

${ }^{46}$ CBOS (Centre of Public Opinion Polling), Komunikat "Kosciol w Rzeczpospolitej" (Report "Church in the Repubic of Poland), based on the poll "Aktualne problemy i wydarzenia" (Current problems and events) from February 1999 (Warszawa: CBOS, 1999).

${ }^{47}$ E. J. Dille The Problem of Surgical Sterilization in Publicly Funded American Catholic Hospitals (M. A. Thesis, The University of St. Michael's College 1982) [unpublished] at 26.

${ }^{+18}$ For the explanation of the doctrine (or principle) of double effect, see e.g. J. Boyle, "Toward Understanding of the Principle of Double Effect"' (1980) 90 Ethics 527.
} 
Moral theologians agree, however, that there is no scriptural basis for the prohibition of either sterilisation or contraception in general. ${ }^{+19}$ However, the moral condemnation of contraception and sterilisation is to be found in papal pronouncements (Encyclical), starting with Casti Connubit ${ }^{450}$ in 1930, through Humanae Vitae ${ }^{451}$ in 1968, and followed lately by several pronouncements of Pope John Paul II, one of which was Evangelium Vitae ${ }^{+52}$ in 1955. All of them are unambiguous in declaring stcrilisation immoral and prohibited by the Catholic religion. Popes invoke natural law, the constant and absolute tradition of church teaching about sterilisation, and arguments flowing from the implications of other moral principles and their interrelation with issues of contraception.

It has been stated with regard to all forms of contraception that they lead to the breaking of the unity of love and reproduction. Even though, the church has accepted natural methods of birth-control, and thus, accepted the possibility of sexual acts which would not lead to conception of the offspring, nevertheless, the employment of artificial means of contraception is condemned as a conscious. intentional breaking of the link between the sexual acts and conception. It is said to ruin the deeper meaning of the sexual act. the purposefulness of

\footnotetext{
"49 See e.g. J. E. Smith, Humanae Vitae: A Generation Later (Washington. D.C.: Catholic University of Americal Press, 1991) at 129.

${ }^{\text {sso }}$ For an English translation of Casti Connubii, see for example Five Great Encyclicals (New York: The Paulist Press, 1956) at 77-117 [hereinafter: Casti Connubii]. In the encyclical we read: "any use whatsoever of matrimony exercised in such a way that the act is deliberately frustrated in its natural power to generate life is an offence against the law of God and of nature, and those who indulge in such are branded with the guilt of grave sin." ${ }^{+51}$ "Humanae Vitae" in R.G. Hoyt, ed., The Birth Control Debate (Kansas City, Mo: National Catholic Reporter, 1968) at 113-140. See also Smith, supra note 449 at 272-295. The encyclical reads: "we must once again declare that the direct interruption of the generative process already begun, and above all, directly willed and procured abortion, even if for therapeutic reasons, are to be absolutely excluded as licit means of regulating birth. Equally to be excluded, as the teaching authority of the church has frequently declared, is direct sterilisation, whether perpetual or temporary, whether of the man of the woman. Similarly excluded is every action which, either in anticipation of the conjugal act, or in its accomplishment, or in the development of its natural consequences, proposes, whether as an end or as means, to render procreation impossible."

${ }^{452}$ Excerpts from Evangelium Vitae in English were published in "Pope John Paul II on Abortion, Contraception. and Euthanasia" (1995) 21 Population and Development Rev. 689 [hereinafter: Evangelium Vitae]. We may cite here: "But despite their difference of nature and moral gravity, contraception and abortion are often closely connected, as fruits of the same tree. It is true that in many cases contraception and even abortion are practised under the pressure of real-life difficulties, which nonetheless can never exonerate from striving to observe God's law fully [...]." (para. 13 at 690) or "Aside from intentions, which can be varied and perhaps can seem convincing at times, [...], we are in fact faced by an objective 'conspiracy against life', involving even international institutions
} 
sexuality, ${ }^{453}$ breaking the principle of the "inseparability of the unitive and procreative meanings of marriage." $" 454$

In addition to the above aspects, sterilisation, has additional unethical features, that make it even less morally acceptable in the Catholic church teaching than other methods of contraception. In the part entitled "Sterilisation" of Casti Connubii, we read:

Finally, that pernicious practice must be condemned which closely touches unon the natural right of man to enter matrimony but affects also in real way the welfare of the offspring. ${ }^{+55}$

And further:

Christian doctrine establishes $[\ldots]$ that private individuals $[\ldots]$ are not free to destroy or mutilate their members, or in any other way render themselves unfit for their natural functions, except when no other provision can be made for the good of whole body.

Sterilisation deprives permanently of the ability to procreate. which. in view of the Catholic theology, is the basic and sacred human capacity. ${ }^{+56}$ It is also considered as the mutilation of the body. ${ }^{457}$ which is not justified by the necessity to save life. ${ }^{458}$ Finally it is an attack on human dignity as depriving it of the power and capacity to create life. ${ }^{+59}$

(3) The role that the church teaching should play in the legislative process

I will start the discussion concerning the role the Catholic church teaching on sterilisation should play in the legislative process, with the following remark by Atkinson and Moraczewski, who noted an easily observable fact: "The teaching of the popes on contraception and sterilisation seems to be widely disregarded by Catholics. ${ }^{\$ 60}$ In 1988 , in a survey conducted in Poland, which did not target solely Catholics, but was conducted on a representative national

engaged in encouraging and carrying out actual campaigns to make contraception, sterilisation and abortion widely available." (para. 17 at 692).

${ }^{453}$ S. Olejnik, Etyka Lekarska (Medical Ethics) (Katowice, Poland: Wydawnictwo Unia, 1995) at 33.

${ }^{454}$ B. M. Ashley \& K.D. O'Rourke, Health Care Ethics: $A$ Theological Analysis, $4^{\text {th }}$ ed. (Washington D.C.:

Georgetown University Press, 1997) at 209.

${ }^{455}$ Casti Connubii, supra note 450.

${ }^{456}$ Ashley \& O'Rourke, supra note 454 at 289.

${ }^{457}$ See e.g. Dille, supra note 447 at 26.

${ }^{458}$ Ibid. at 288.

459 Olejnik, supra note 453. 
sample, (although, it must be recalled that Catholics constitute around $95 \%$ of the Polish society) people were asked the following questions:

A married couple uses contraceptives in order to prevent pregnancy:

I. Is it sinful?

2....

3. Does one have the right to do it?

4. Is it proper?

There was $67 \%$ positive and $24 \%$ negative answers to the first question. which indicates that most Poles are aware of the church's teaching. However, at the same time, $65 \%$ of respondents claimed that despite it being sinful, one has the right to use contraceptives. Similarly $60 \%$ of Poles replied that it was proper to use them. Only $25 \%$ answered "no" to the third question and $32 \%$ thought it was not proper to use contraceptives. ${ }^{162}$ This wide disregard both is a result of. and results in, questioning the church's doctrine on contraception and its authoritativeness. conclusiveness and appropriateness in contemporary times. The prohibition of artificial means of contraception is, in the opinion of a significant number of scholars. inconsistent with and contradictory to the church's teaching on permissibility of natural methods ${ }^{163}$ and the fact that the church accepts the need to control the number and spacing of children in difficult life situations. ${ }^{16+}$

Prohibition of contraception was also often justified by its correlation with other morally condemned behaviours, such as, for example: abortion, premarital and extra-marital sex. This idea has appeared in the Lord Denning's opinion in Bravery, when he talked about opening the way to licentiousness. Whether one agrees with the church's moral evaluation of the above acts or not, one aspect of this consequentionalist argument is essential. As it was pointed out by James Arraj, to support this argument it is necessary to bring enough evidence of the link

\footnotetext{
${ }^{+60} \mathrm{G}$. Atkinson \& A. Moraczewski, A Moral Evaluation of Contraception and Sterilisation: A Dialogical Study, (St. Louise, Mo: Pope John XXIII Medical-Moral Research and Education Center, 1979) at 29.

t61 J.Kurczewski, "Carnal Sins and Privatization of the Body (Research Notes)" in J. Kurczewski \& A. A. Czynczak, eds., Family, Gender, and Body in Law and Society Today (Warszawa: Sociology Department, Institute of Applied Social Sciences, WPR i PS, University of Warsaw, 1990) 269 at 289.

$\$ 62$ Ibid.

${ }^{163}$ See e.g. B. Maddox, The Pope and Contraception: The Diabolical Doctrine, (London: Chatto \& Windus, 1991) at 32. See also Atkinson \& Moraczewski supra note 460 at 51-54.
} 
between the use of contraceptives and the engagement in any of the mentioned above activities. ${ }^{465}$ Charles R. Meyer speaks about the sexual revolution, and indeed, there are a lot of changes in viewing human sexuality and sexual relations, as well as a decrease in the number of marriages and an increase in a number of marriage break-downs, ${ }^{466}$ that are taking place also in Poland. ${ }^{167}$ However, it is not obvious whether the use of contraceptives is a cause or a result of such changes. It has to be emphasised that the Catholic chirch is mainly concerned with the fact that if it pronounces that contraception is permissible, people would interpret that as also accepting the other "evils". However, changes in a society's norms, values and behaviours take place also in spite of limited accessibility to contraceptives notwithstanding the church's condemnation. On the level of empirical evidence. countries with a high prevalence of contraception also have the lowest level of abortions. It may be suggested that this can be explained simply because contraception enables people to avoid this more drastic measure. Also, the evidence shows that sterilisation for contraceptive purposes is mostly used by married couples. and can actually lead to the further stabilisation of the marriage rather than to the weakening of the marriage bond. ${ }^{468}$

One more argument questioning the validity of the Catholic church doctrine on contraception, formulated in feminist discourse, concerns the fact that women were never involved in the process of formulating the doctrine and that their views and moral stance on this issue have never been taken into account. Rather, it was celibate men deciding about issues that affect women in a disproportionate way.

The experience of couples who use sterilisation as a contraceptive method seems to be not fully appreciated by the church teaching. Although the Casti Conubii equates sterilisation with mutilation, it also talks about the possibility of the justification of this procedure "for the

\footnotetext{
tot See e.g. Humanae Vitae, supra note 451 , para. 16 at 126.

${ }^{405}$ J. Arraj, Is There a Solution to the Catholic Debate on Contraception?, (Chiloquin, OR: Inner Growths Books, 1989) at 89-91.

106 "Responses to Humanae Vitae" in Hoyt, supra note 451, 155 at 195.

${ }^{+67}$ In the document "Pro-family Policy" the government has discussed such processes as: decrease in the number of couples entering marriage, increase in the number of divorces, as well as a proportionate increase of a number of children born out-of-wedlock, as compared to the overall number of births - see "Pro-family Policy', supra note 376 at $9-10$.
} 
good of the whole body". This "good" is treated narrowly as "saving life" and excludes the experiences of people who have undergone sterilisation describing it as "subjective satisfaction." ${ }^{169}$ But surely, just as antiquated religious prohibitions are amenable to flexible interpretation, so too can their exceptions be generously interpreted. Then, it is reasonable to ask whether the good of the whole body, should encompass the "goods" of being able to support one's existing family wilh security, being able to share intimacy without constant fear of pregnancy and being able to use one's full potential for the up-bringing and welfare of children that the family they already have. ${ }^{170}$

The next reservation with regard to the moral condemnation of sterilisation. concerns the view that it is an "attack on human dignity". which has been similarly expressed by Denning as "degrading for the man himself". The sacred power to procreate and to create new life will never be fully appreciated if a man or a woman does not have a free choice to decide about using this capacity. As well. we can say that such view leads to questioning of the dignity of those who are infertile or those who are being in extreme life conditions and are not able to appreciate the "miracle" of the birth of a next child. The net effect of these and other objections towards the doctrine is the widespread practice of contraception by Catholics. a large number of whom believe it to be in accordance with their conscience and Catholic morality.

Despite, or perhaps because, of that fact, there is pressure from authorities of the Catholic church on Polish state decision-making bodies to formulate law and policies in accordance with the church's moral teaching. ${ }^{+71}$ As Rebecca Cook and Bernard Dickens write:

Religious authorities are not always content to trust the exercise of individual moral judgement within liberal laws that accommodate moral error, but favour compulsion and compliance with religious teaching through inflexible laws. ${ }^{472}$

\footnotetext{
${ }^{108}$ See discussion in Chapter II, Part B, above.

${ }^{+09}$ Ashley \& O'Rourke, supra note 454 at 289.

${ }^{+70}$ See the discussion in Chapter II, Part B (Enforced parenthood) above.

${ }^{47}$ See e.g. Evangelium Vitae, supra note 452 , para. 59 at 694 . In this document the pope reminds about responsibilities of the legislators for approving of and promoting abortion laws.

t72 R.J. Cook \& B.M. Dickens "Voluntary and Involuntary Sterilisation: Denials and Abuses of Rights" (2000) 68 Int'l J. Gynecology \& Obstetrics 61 at 64 .
} 
The explanation of the phenomena of the "lack of trust" is not difficult, as the legal order does have a certain influence on the formulation of values. However, it is not the role of the state to replace the church in its moralising capacity. The role of the state is different from a role of the church. The mission of the former is the promotion and protection of welfare and happiness of all society. ${ }^{473}$ The legal order needs to be based on moral values, but these values ought to be shared by at least the majority of its citizens, be a form of collective morality and cannot be highly controversial.

In a pluralistic society, which exists now in Poland, the Catholic church, like any other community and group - social or political - has a full right to participate in the discussion concerning sterilisation. This right is guaranteed in the Polish Constitution, together with the obligation for national authorities to remain impartial in matters of religious and philosophical views. ${ }^{47}$ Imposition of Catholic church teaching onto non-Catholics would amount to the violation of their right to freedom of conscience. This would also be a form of fundamentalism. requiring the society to live according to the church's own norms, because:

it is a dispenser of revealed truth about values, and whoever resists raises a hand against Christ himself, persecutes the Church, discriminates against the faithful, and betrays the Motherland. ${ }^{175}$

In conclusion, it can be said with regard to the role of the Catholic church teaching on the legislative process, that the church, as any other religious or social institution is authorised to take part in public life and attempt to influence decisions of the national authorities. On the other hand, the national authorities, as required from them by the Polish Constitution, are obliged to remain impartial in matters of religious views. For this reason, they cannot impose on society, through legislation, values that are not commonly shared by the whole society and which have as its justification only the authority of one of the religions.

${ }^{37}$ B.M. Appleby, Responsible Parenthood: Decriminalizing Contraception in Canada, (Sydenham, Ont., 1996) at 191-194.

${ }^{474}$ Constitution, supra note 120 , Art. 25.

${ }^{475}$ A. Michnik, "The Clean Conscience Trap" (1998) 7 East European Con. Rev. 67 at 71. 
Sterilisation as an attack on secular morality - family values and Polish "identity"

It has been pointed out in the document "Pro-family Policy" prepared by the Polish government that family is one of the most durable values in the Polish society. ${ }^{476}$ And, indeed, the public opinion polls show that Poles put family first on the list of priority values, as the most important thing in their lives. There can be some doubts as to whether this fact is really specific to Poland, and not shared by other societies, but we can accept that this is something that should not be ignored with regard to the Polish society. Another characteristic value of the Polish society is the concept of the "Matka Polka" (Polish Mother) - a traditional model of a Polish woman, a mother, caring for the family, sacrificing herself for family and the nation. ${ }^{+77}$ Sterilisation, as the deprivation of the ability to procreate, and, thus, closing the option to multiple members of the family, could cause concern as being an attack on the value of the ability to procreate. the value of the family and the concept of "Matka Polka", which are regarded as part of the Polish national identity.

The reaction to such concerns can be considered from many different perspectives. With regard to the first value - treating family as the highest good, we need to ask how "the family" is understood. Does it necessarily imply children? And, even if it does, does it imply a large family, or is it simply that despite the size and composition of a family, it is still first on the list of priorities. Furthermore, as argued in Chapter II, Part B, the use of sterilisation can enhance the welfare of the family, and be considered as a pro-family factor, although maybe not in the sense referred to in the Pro-family policy. This is the most important ideological tension - the choice between family values as family welfare or simply as instrument to the growth of the Polish population. The answer to this value choice must be given by the society itself, because it is the society's welfare which is at stake. Sterilisation is most commonly used by married couples which already have several children, and are happy with the size of the family they have, and want to do everything in their capacity to enhance the welfare of their existing family. One of the ways to do so, in their opinion, is to not have more children, so as not to compromise the time,

\footnotetext{
${ }^{+76}$ Pro-family Policy, supra note 375 at 4.
} 
attention, care and resources they have for their existing children. Thus, it is not necessarily inconsistent with family values to enhance the means to control the timing of births and size of the family. With regard to the sanctity of the ability to procreate, it must be emphasised that this ability can only be valued and appreciated if it involves a true freedom of choice. Without true choice about when to have children, and how many, this "value" mutates into the duty to procreate.

On the other hand, the model of "Matka Polka" again - can be questioned from the perspective of women themselves. The question is whether this is their vision of the womanhood. or whether the society has evolved or is evolving or at least should be evolving to a different model of womanhood.

Finally, there are three basic questions about legitimacy of these two values: the ideal of "Matka Polka" and an abstract value to of the ability to procreate. The first is whether they really are considered by the society itself as essential to the preservation of the Polish identity. The second question is whether their legitimacy is not undermined by the fact that women were mostly excluded from their development. And the last question is their potential for harm. a theme that will be recurring throughout this work.

\section{Collective versus Individual Morality}

The conviction about the need to protect morals must be shared by the society itself, and by its significant sector, and not solely by the church authorities, or the circles closest to the Catholic church. It is necessary to demonstrate that sterilisation is condemned by the significant sector of the society and considered essential by the society to protect its "collective morality." This point - that there is a need for widespread consensus with regard to collective norms - is supported by two European Court of Human Rights' cases. In the Dudgeon case, the government of the United Kingdom argued that the proposed decriminalisation of private homosexual acts met with substantial resistance in Northern Ireland. It has pointed not only to the opposition from religious groups, but also to the lack of support for the change in the political formations, as well

\footnotetext{
${ }^{4 \pi}$ See e.g. Kulczycki, supra note 108 at 490.
} 
as to the fact that general public opinion was evenly split on the question of the reform. ${ }^{478}$ It was this fact, the fact that there exists "a strong body of opposition stemming from a genuine and sincere conviction shared by a large number of responsible members of the Northern Irish community that a change in the law would be seriously damaging to the moral fabric of society" and "its existence among an important sector of Northern Irish society", that the Court found relevant with regard to the protection of morals. ${ }^{479}$ Similarly, in the case of Open Door Counselling \& Dublin Well Women v. Ireland, ${ }^{480}$ the signal for the Court that it needs to take into consideration the specific moral climate in Ireland, was the result of the 1983 referendum. in which the majority of the Irish people voted against the liberal law on abortion. ${ }^{+81}$

If public opinion polls are inductive, as suggested by the Open Door and Dudgeon cases. there appears to be a widespread consensus forming in favour of liberalising sterilisation in Poland. Although, besides the above mentioned opinion poll from 1988 concerning contraception in general, there has not been a national opinion poll conducted on the specific issue of decriminalising sterilisation. nevertheless, some indication flows from the 1996 survey on reproductive health in Poland conducted by the Federation for Women and Family Planning, an independent non-governmental organisation. $74 \%$ respondents of the survey stated that sterilisation should be legalised for contraceptive purposes, $19 \%$ are opposed to its legalisation and $7 \%$ did not have an opinion on this issue. ${ }^{182}$ The survey does not allow a certain measure of what the majority of the society thinks about sterilisation, as it was conducted on a nonrepresentative group of society and directed only at women. Nevertheless, this is the only source of knowledge about the opinions of at least some fraction of the society on this issue, and, supports a tentative hypothesis that Polish society does not seem to share the opinion that the ban on sterilisation is necessary for the protection of national integrity.

\footnotetext{
${ }^{478}$ Dudgeon, supra note 250, para. 25. As for the general opinion, the government has invoked results of the opinion poll conducted in 1978.

${ }^{479}$ Ibid. para. 57.

${ }^{480}$ Open Door, supra note 256.

${ }^{481}$ Ibid. para. 63 at 263.

${ }^{482}$ Reproductive Health of Women in Poland, supra note 41. The poll serving as basis for this Report has been conducted on a non representative group of women, because to a large part they came from supporters of the Federation itself.
} 


\section{Role of Women in Shaping "Collective Morality"}

In response to this, the government could argue that the laws are the result of decisions of democratically elected parliamentarians, who represent the whole society and are authorised by their electors to make legislative decisions on their behalf. For this reason, they should be able to decide on what is necessary for the protection of morals of the society. This argument appeals to the "margin of appreciation" doctrine which mandates deference to national authorities. However, it fails on two grounds.

First of all, the proscription of sterilisation was introduced a long time ago, and although the subsequent legislatures can be held responsible for maintaining the status quo, they have never been squarely faced with the question of proscription and have never "consciously" decided that this measure is necessary for the protection of morals of the current society. Secondly, as suggested by Angela Thompson, in her analysis of the European Court's decision in the Open Door ${ }^{183}$ case. delegating powers to decide on the issues of sexual morality and sexual health or rights to national authorities without sufficient international supervision means that these issues will be resolved by male-dominated governments and legislatures. deeply rooted in patriarchal traditions, from which women's voices have been excluded or marginalised. As a result, by allowing too broad a margin of appreciation with regard to matters of reproductive health and rights, the European Court could disproportionately harm women. ${ }^{\text {t8t }}$ Until national authorities show a true commitment to making the equality of men and women a reality and ensure that women's voices are given prominence in political debate, they cannot be entrusted with deciding on the issues of reproductive rights, which have such a profound meaning on women's lives.

The disproportionate influence on women of all issues relating to reproduction, including the right to access to sterilisation, can explain why, even though the right is denied to men to the same degree as to women, men have not raised claims for change in the law. Men do not have to

\footnotetext{
\$83 Open Door, supra note 256.

48+ A. Thompson, "International Protection of Women's Rights: An Analysis of Open Door Counselling Ltd. and Dublin Well Women Centre v. Ireland" (1994) 12 Boston U. Int'I L.J. 37 I at 397.
} 
experience to the same degree as women the denial of reproductive rights or the rules, which result in limited contraceptive choices. In short, they do not experience to the same degree as women do, how not being able to control fertility can deny one the right to shape one's life according to one's own needs or the needs of one's existing family. The European Court and Commission have been in favour of giving the wide margin of appreciation to the national authoritics in the matters of morals. ${ }^{485}$ But, given the unique nature of reproductive rights. how they are interrelated with the situation of women. and the fact that Polish national authorities have to date excluded or marginalised women and their voices. speaks against a wide "margin of appreciation" in the case of anti-sterilisation law.

\section{Scrutinising the Necessity of the Measure}

Regardless of whether the state is given broad or narrow margin of appreciation, the assessment of whether a specific measure is necessary for the protection of morals always has to be scrutinised with regard to its compliance with international human rights standards. This has been always emphasised in the jurisprudence of the European Court and Commission of Human Rights. ${ }^{486}$ Arguments that the retention of the anti-sterilisation law is necessary to protect the moral fabric of society needs to be scrutinised, according to the European organs, with regard to: the existence of the pressing social need to retain the impugned restriction. the ways this issue has been resolved in other domestic jurisdictions. and the proportionality between the measure and the aim pursued by it.

\section{The significance of the lack of enforcement}

Voluntary sterilisation operations for contraceptive purposes are being from time to time performed in Poland regardless of the ban. Despite that fact, the law has never been enforced against doctors who agree to perform them, nor is there any evidence of a demand from the society to have the laws enforced. These circumstances suggest that there is no "pressing social need" to employ the measure to protect the moral fabric of the society, which is a requirement for

\footnotetext{
${ }^{485}$ See supra note 276 and accompanying text.

${ }^{486}$ See e.g. Dudgeon, supra note 250, para. 52.
} 
the measure to be viewed as "necessary in democratic society". ${ }^{487}$ The non-enforcement of laws combined with the lack of demand from society to enforce them, produced this result in the European Court and Commission's cases of Dudgeon, Norris and Modinos. ${ }^{488}$

\section{Development of the European consensus - evidenced by the domestic legal orders}

Another argument against the anti-sterilisation law being "necessary in a democratic society" is the fact that this measure has not been sustained in a majority of other countries, including European countries. ${ }^{489}$ By the 1970 s most of them had reformed their laws to authorise voluntary sterilisation for contraceptive purposes. Post-communist countries including Romania, Hungary, Czech Republic, and the Russian Federation have explicitly liberalised or clarified the legal status of sterilisation after the demise of communism. Of course, none of the countries is completely identical to Poland. with regard to the society's moral values. Nevertheless, this consistency in Europe, allows us to talk about an emerging "European consensus" with regard to legalising sterilisation. This is even more so if we look at several post-communist countries who

\footnotetext{
${ }^{187}$ See supra note 262 and accompanying text.

${ }^{488}$ See e.g. Dudgeon, supra note 250, para. 60 at 167.

${ }^{189}$ Countries of the European Union allowing sterilisation for contraceptive purposes: Austria - since 1974 - see Annual Review of Population Laws 1974. (Medford, Mass: Tufts University, 1975) at 16 [hereinafter: ARPL]. Denmark - since 1973 - see ARPL. 1974, ibid. at 18., Finland - since 1970 - see ARPL, 1985-86 (New York: UNFPA, 1987) at 23., Germany - since 1976 - see .ARPL. 1976. (Medford, Mass: Tufts University, 1977) at 22. Iceland - since 1975 - see ARPL, 1976 at 23., Italy - since 1978 - see ARPL 1987-88,(New York: UNFPA, 1989) at 28., Luxembourg - since 1978 - see ARLP. 1978 (New York, NY: UNFPA. 1978) at 7., Netherlands - no specific law - see J.G. Ross et al., Voluntary Sterilisation: An International Factbook (New York, NY, 1985) at 15. Portugal - since 1984 - Law No, 3/84 on Sex Education and Family Planning, cited in ARPL, 1984 (New York. N.Y.: UNFPA, 1987), Spain - since 1983 - see ARPL, 1983-84 (New York: UNFPA, 1984) at 53.; Sweden - since 1975 - see International Advisory Committee on Population and Law, ARPL, 1975 (Medford. Mass: Tufts University, 1976) at 15. , United Kingdom - since 1972- see J. Stepan \& E.H. Kellogg "The World's Laws Concerning Voluntary Sterilization for Family Planning Purposes" (1974) 5 Cal. W. Int'l L. J. 72 at 75. Countries of the European Union where the status is not clear: Belgium, France, Ireland, Greece. The situation of France and Ireland is discussed below. With regard to Belgium, based on the information acquired from the AVSC International, sterilisation is a popular procedure. No such data was available with regard to Greece.

Other European countries, where sterilisation for contraceptive purposes is legal: Norway - since 1977 - see ARLP. 1978 ibid at 7. , Switzerland - since 1981 - see ARPL, 1981 (New York, NY: UNFPA, 1982) at 33.

Eastern European countries, where sterilisation for contraceptive purposes is legal: Czech Republic - since 1991 see ARPL, 1991, (New York: UNFPA, 1989) at xx., Hungary - at present regulated by Art. 187 of the Public Health Care Act, and Welfare Ministry Order No. 25/1998 (VI. 17) - see The CRLP, supra note 429., Romania - since 1989/90 - see ARPL, 1989 (New York, NY: UNFPA, 1990), Section 240 and ARPL, 1990 (New York, NY: UNFPA, 1991) at 18 (Ibid. at 30).
} 
have followed the European consensus in striving to promote higher standards of human rights protection in this respect, as soon as they have ceased to be restricted by the totalitarian regimes. In the Dudgeon ${ }^{400}$ case, in the European Court's decision we read: [T] he Court cannot overlook the marked changes which have occurred in this regard in the domestic law of the member States. ${ }^{491}$ Similarly, in the Marckx ${ }^{+92}$ case, it has been stated:

[The Court] cannot but be struck by the fact the domectic law of the great majority of the member States of the Council of Europe has evolved and is still continuing to evolve in company with relevant international instruments ... ${ }^{593}$

Since we are discussing the issues of morality and protection of morality, we should. in particular, turn to the way this question has been resolved in countries that have a similar moral climate to Poland; that is, countries with strong Roman Catholic traditions. In this respect, such countries as Austria and Italy, which legalised sterilisation for contraceptive purposes in the 1970s should be pointed out. In another Catholic country. Ireland. which has frequently raised the protection of morals as a justification in proceedings before the European tribunals in cases concerning abortion and homosexual behaviour, the legal status of sterilisation is not clear. However, the evidence shows that this procedure is fairly popular in this country. ${ }^{194}$ There are also cases of court proceedings concerning negligence in performing sterilisation. ${ }^{495}$ This evidence suggests that sterilisation is considered legal in Ireland. All of the foregoing demonstrates how far Poland is out-of-line compared to other European countries including those dominated by Catholic doctrine. The only country that has officially declared, although not through legally binding instruments, the illegality of sterilisation for contraceptive purposes is

Other European countries allowing sterilisation as a method of family planning: Turkey - since 1983 - see Ross et al., ibid.

${ }^{490}$ Dudgeon, supra note 250.

s9l Ibid. para. 60.

$\$ 92$ Marckx, supra note 208.

${ }^{493}$ Ibid para. 41.

194 Letter from Karen Kiernan, Irish Family Planning Association (19 July 2000): “[V]asectomies and female sterilisations are relatively common and although there are waiting lists, can be obtained through ... national health services and in all hospitals."

${ }^{495}$ See e.g. Walsh v. Family Planning Services Lid Orr and Kelly. 9 April 1992, Suprem Court. (Irish Law Times, Vol. I1, No. 4, April 1993, p.90) cited in ARPL, 1992 (New York, NY: UNFPA, 1996) at 17. The case concerned negligence in performing elective vasectomy. 
France. ${ }^{196}$ As a result, French physicians have been more reluctant to provide this service. ${ }^{.97}$ Nevertheless, the procedure is still common among French people for contraceptive purposes. ${ }^{498}$ Also "there is an evolution in favour of the legal recognition of voluntary sterilisation for nontherapeutic reasons." ${ }^{N 99}$ This is in a big contrast to the situation in Poland.

Development of the European consensus - evidenced by the regional "legislation"

This almost unequivocal trend in Europe can be further supported by an example from another category of evidence of the development of the European consensus - the Resolution of the Committee of Ministers of the Council of Europe entitled "Legislation affecting fertility and family planning" adopted on 14 November $1975 .{ }^{500}$ Part C of the Resolution recommends to the countries of the Council of Europe to make sterilisation available as a method of family planning. ${ }^{501}$ In 1975. Poland was not yet a member of the Council of Europe. For this reason it also did not have the choice to make reservation to the Resolution. as Belgium and Germany did with regard to abortion. and as Ireland did with regard to the entire document. However, it is not suggested here that the Resolution should be treated as a binding instrument. in which case such facts as reservations or that Poland was not a signatory of this document. would have great importance. Rather, this Resolution is an indication of the development of a European consensus. which has been followed by legislative changes in the significant majority of the European countries. This Resolution is an evidence of the development of a standard of protection at which European countries are urged to aim.

\footnotetext{
${ }^{996}$ See e.g. French Order of Physicians, ARPL, 1983-84, supra note 489 at 51 . Information as to the illegality of contraceptive vasectomy in France and the offer of British organisation to provide this service to Frenchmen has recently appeared in newspapers, see e.g. "Frenchmen Offered Cut Price in London" Herald Tribune (14 August 2000) at 5.

${ }^{497}$ A.M. Dourlen - Rollier, "A Lawyer's Perspective" in Z. Bankowski, J. Barzelatto \& A.M. Capron, Ethics and Human Values in Family Planning, (Geneva: Council for International Organizations of Medical Sciences, 1989) 278 at 279.

${ }^{199}$ UN World Contraceptive Use, supra note 60. Data from 1994 estimates rates of sterilisation use for $8 \%$ (both male and female).

${ }^{999}$ Letter from A.M. Dourlen-Rollier (18 July 2000).

${ }^{500}$ Council of Europe, Committee of Ministers, Resolution (75) 29,14 Nov. 1975, reproduced in $A R P L, 1975$, supra note 489 at 3 .

${ }^{501}$ lbid. at 13.
} 


\section{Test of proportionality}

The final test of the necessity of the measure to protect morals: family values, value of the ability to procreate, or national identity through the protection of the ideal of Matka Polka, is the test of proportionality. On the one hand, we have the implied implications of decriminalising sterilisation on the society's moral fabric. And on the other. we have the impact of the present situation - when sterilisation is criminalised - onto the lives of individuals. With regard to the interest in sustaining the status quo prohibition. a lot of questions have been asked in this section: the extent to which Polish society agrees with the immorality of sterilisation as a contraceptive measure, the extent to which Polish society shares the view that its prohibition is necessary to protect morals, the implications of the fact the measure is non-enforced, or the controversy whether sterilisation represents a pro-family value or is directed against the family values (as the Pro-family Policy would suggest). On the other hand, we have analysis of the various and numerous ways in which the criminalisation of sterilisation affects the lives of individuals and the ways in which the lack of access to this method affects the Polish society, as analysed in Chapter II Part B, by, among others: exacerbating inequality of women. compromising the financial and social well-being of a family - durability of a relationship of partners and the social, emotional or intellectual development of children as well as casting a shadow on choices made by doctors, or individuals, who view this method as beneficial for. not only their own wellbeing, but supposedly the well-being of their partners or families, and finally, by forcing women to turn to abortion in cases of unwanted pregnancies. We should also take into account the fact that the legal system and the ethical system do not necessarily conflict simply by the fact of decriminalisation of certain activity, which can be regarded by some as unethical. The decriminalisation does not mean that the ethical choices of those who do not approve of the method are not respected. As Cook and Dickens provide:

[M] any laws ...may attempt to observe two principles of:

a) not compelling unethical behaviour

b) accommodating ethical choice; 
but they do not necessarily outlaw behaviour simply because it is unethical. ${ }^{.02}$

If the potential implications of anti-sterilisation law on the lives of individuals are so numerous and if there is no unanimity in evaluating the measure in question as necessary to protect public morals, and since its abandonment does not compel those who see it as conflicting with their value to act accordingly, the measure used - criminalisation - may be considered as not proportionate to the goal pursued. ${ }^{\leq n ?}$

Another matter is that even if the substantive majority of the society did consider sterilisation as conflicting with their value system, the question remains whether criminalisation is the least restrictive measure to address the need to protect the value system. Criminalisation of any activity requires a careful scrutiny of the basis for criminalisation. ${ }^{50-1}$ If it was a moral norm to constitute the only basis for criminalisation. it is necessary to consider carefully whether such criminalisation is truly necessary to protect this moral norm and whether the criminalisation will achieve this goal. ${ }^{505}$ Similar principle has been expressed in the document submitted by the Polish government together with a project of the new Polish Criminal Code. ${ }^{506}$ In this document accompanying the government's proposal, the government argued that the new criminal codification is based on the principle of subsidiarity. According to this principle. criminal law should only be used as ultimo ratio, if public goals and interests cannot be achieved through other means. ${ }^{507}$ One can argue that the criminal ban on sterilisation is not the least restrictive measure to protect family values or the ideal of Matka Polka, or the Christian sexual morality and will not assist in a sufficient way in advancing these goals.

\footnotetext{
S02 Supra note 113 at 128.

${ }^{503}$ See e.g. the European Court's reasoning in Dudgeon, supra note 250 para. 61 .

sat See e.g. the in-depth analysis of various basis for criminalising activities and guideliness - procedures that should be followed before the decision about criminalising is made in L. Gardocki, Zagadnienia Teori Knyminalizacji (Theory of Criminalisation) (Warsaw: PWN, 1990).

${ }^{505}$ lbid. at 173-174.

${ }^{506}$ Each proposed bill needs to be accompanied by a document explaining the justification for the introduction of such proposal and explaining solutions proposed by the particular proposal.

${ }^{50 t}$ Uzasadnienie rzadowego projektu kodeksu karnego (Justification of the Government's Proposal of the Criminal Code), published e.g. Nowe kodeksy karne $-z 1997$ r. z uzasadnieniami: Kodeks karmy, Kodeks postepowania karnego, Kodeks Karny Wykonawczy (New Criminal Codification from 1997) (Warszawa: Wydawnictwo Prawnicze, 1998) 116 at 116.
} 


\section{PART D. Protection of Health}

[N]one of us is likely to forget that we live in a century which, as a matter of relatively recent history, has witnessed experiments carried out in the name of eugenics or for the purpose of population control, so that the very word "sterilisation" has come to carry emotive overtones. ${ }^{508}$

\section{introduction}

The above quote comes from the case of In re $B .^{509}$ decided in the British House of Lords in 1987, of a mentally handicapped girl ( 17 years old) whose mother, along with the council of the residential institution she lived in applied for the court's approval to get the girl sterilised. The reasons submitted by applicants for the need to have this operation was the girl's inability to cope with pregnancy. child-bearing and child-rearing along with her inability to use other contraceptive methods. The court decided that the operation was in the girl's best interests as protecting her from the negative consequences of her becoming pregnant. which, in the girl's case would be "an unmitigated disaster."

[The girl] has all physical sexual drive and inclinations of a physically mature young woman of 17 ... [This results in the existence of]a significant danger of pregnancy resulting from casual sexual intercourse... To incarcerate her or reduce [her] liberty as she is able to enjoy would be gravely detrimental to the amenity and quality of her life..."

The main stress of this consideration was the possibility that in order to prevent pregnancy, the girl's freedom of movement, ability to stay by herself would be restricted. However, it can also be understood as emphasising the importance of sexual intimacy, the ability to have sexual freedom, as one of aspect of social development and well-being of the girl. Lord Hailsham has

\footnotetext{
${ }^{508}$ Lord Oliver of Aylmerton in In re B. (A Minor) [1988] I A. C. 199 at 207. It was emphasised throughout the House of Lords' proceedings that "[the case] has nothing to do with eugenic theory or with any attempt to lighten the burden which falls on those who have care of [the girl]' (at 199). It was also emphasised that there is no general authorisation for the non-consensual sterilisation of mentally handicapped people, unless it is necessary for their own welfare and best interests and is the last resort. (at 200). Lord Hailsham of St. Marylebone have criticised the decision in the Canadian case In re Eve 3 I D. L. R. $\left(4^{\text {th }}\right)$ 1. which concluded that the sterilisation operation of a mentally handicapped person should never be authorised for non-therapeutic reasons, as "in startling contradiction to the weifare principle which should be the first and paramount consideration in [such] cases." (at 202).

${ }^{509}$ In re $B$, ibid.

s10 Ibid. Lord Bridge of Harwich at 205.

"II Ibid. Lord Hailsham of St. Marylebone at 202-203.
} 
also referred to the decision in the Canadian case In re Eve $e^{512}$ which concluded that the sterilisation operation of a mentally handicapped person should never be authorised for nontherapeutic reasons. He criticised it as being "in startling contradiction to the welfare principle which should be the first and paramount consideration in [such] cases." likely effect of this decision, namely the denial of Eve's social development and sexual expression, seems not to have been considered" ${ }^{\prime \prime 1}$ in this case.

Besides pointing to the harm to sexual health and the well-being of a person deprived of the sterilisation option, another important aspect of the $\ln$ re $B$ case is that it concerned a "nonconsensual" sterilisation, since the girl herself, was not capable of giving a competent consent to the procedure. The judges in this case had to make the decision on behalf of the girl. By doing so. they had to consider, more generally, the benefits of the sterilisation operation and the consequences of the rejection of this option, as well as the social evaluation of this procedure. It was stated in the proceedings of the case that:

[T] The arguments advanced against the adoption of the expedient of sterilisation operation are based almost entirely - and indeed. understandably so - upon its irreversible nature. ${ }^{515}$

In another House of Lords case concerning sterilisation - In re $F^{516}$. decided in 1989 regarding, however, an adult woman we can read:

In considering that question [of approving sterilisation operation of $F$ ], it is necessary to have regard to the special features of such an operation. These features are: first. the operation will in most cases be irreversible; secondly, by reasons of the general irreversibility of the operation, the almost certain result of it will be to deprive [a person] of the [right] to bear children.... ${ }^{517}$

Taken together the above statements invoke the main concerns associated with sterilisation's potential harm on the lives of individuals (as opposed to the concerns discussed in the two previous sections of this chapter, which dealt with potential harms to the welfare of the society as

\footnotetext{
S12 In re Eve, 3I D. L. R. (4 $\left.4^{\text {th }}\right) 1$.

${ }^{513}$ In re B, supra note 508 at 202.

Sis C.M. Olesen "Eve and the Forbidden Fruit: Reflections on a Feminist Methodology" (1994) Dal. J. Legal Studies 231 at 233.

515 In re B, supra note 508. Lord Oliver of Aylmerton at 210. [emphasis added]

${ }^{516}$ In re F. [1989] 2 W.L.R. 1025.

${ }^{517}$ Ibid. at 1068. [emphasis added]
} 
a whole): the potential of the sterilisation to be abused ${ }^{518}$ its irreversibility ${ }^{519}$ and the general negative evaluation of sterilisation as a harm to a health of a person (as depriving the person of his/her natural capacity). ${ }^{520}$ I shall start my analysis with the last of these concerns.

\section{Sterilisation as a Health Harm}

I will start by mentioning again, that contraceptive sterilisation has been regarded in Poland as illegal because the criminal offence of inflicting "severe health detriment" has been interpreted in the Polish legal doctrine as encompassing the case of non-therapeutic operation. ${ }^{521}$ The implied health harm of sterilisation is the deprivation of the natural function of a human organism - the ability to procreate. This ability is usually considered as the state of health. thus. in principle, as not requiring treatment. However, Bernard Dickens points out a paradox:

Deprivation of the ability to procreate [according to the Polish Criminal Code] is grouped with deprivation of the ability to hear, see or speak. All four are natural functions, but associating sterili[s]ation with the others reflects the view that it is as unnatural to terminate procreative capacity as it is voluntarily to make oneself deaf. blind or dumb. ${ }^{52}$

The difference between these two cases: sterilisation. on the one hand. and the making oneself deaf, blind or dumb, on the other, is that in the latter, it would be difficult to point to any potential benefits. ${ }^{523}$ On the other hand, the many benefits of sterilisation have been already mentioned in chapter two. In this situation, it is necessary to look closer into the potential health risks and harms of the operation and to see whether there could be balanced by its benefits.

First, we need to recall the risks of the sterilisation operation - the surgery such as: the risk of infection or bleeding, or anaesthesia - related complications. Furthermore, some sideeffects of the method were already mentioned, such as the possibility of more heavy and painful menstrual bleeding. Finally, there is the risk associated with the failure of female sterilisation -

\footnotetext{
${ }^{518}$ The first quote.

${ }^{519}$ Third and fourth quote.

${ }^{520}$ The fourth quote.

521 See the analysis in Chapter II, Part A, above.

sin Supra note 472 at 64.

\$23 Except, perhaps, if we take into account such cases as: a beggar, who counts on the compassion of people because of his disability or a somebody who wishes to avoid working and take advantage of social welfare benefits for disabled (exemple given by Wasek, supra note 10 at 92) or a person who wants to avoid military service (ibid at 93).
} 
the increased risk of an ectopic pregnancy. All these risks need to be seriously considered, however, they should be also evaluated in comparison to risks and side-effects of other contraceptive methods. Most contraceptive means, except for the natural family planning methods are associated with some health risks and side-effects. Furthermore, it has been pointed by many specialists that this method still remains one of the most safe methods of contraception. ${ }^{\text {:s }}$

On the other hand, there are benefits of sterilisation, which include: fear-free sexual intimacy, the positive influence on the overall quality of sexual life or the fear-free sexual intimacy, the ability to be spontaneous and fully enjoy sexual liberty and sexual expression. Furthermore, this method allows a couple to not abstain from intimacy in some situations. in which other contraceptive means would require doing so (e.g. natural family planning, failure in the application of oral contraceptives, or, for instance, in the case of infection caused by IUD). These features allow the couple to fulfil their need for the sexual intimacy, feel less tense. anxious or depressed and more cheerful and relaxed. ${ }^{525}$ what positively influences their overall well-being. Anti-sterilisation law, as limiting contraceptive option, can compromise sexual health and sexual liberty.

The question arises whether it is feasible to see these benefits not only as solely "social" benefits, which are harder to juxtapose with strictly health concerns, but also as health benefits. As it was discussed in Chapter three, this category of benefits has been considered as elements of the definition of reproductive health accepted in the Cairo Programme of Action and the Beijing Platform of Action. ${ }^{526}$ This wide definition has been also reaffirmed in the General Comment 14 of the Committee on Economic, Social and Cultural Rights. ${ }^{527}$ These documents manifest the emerging international consensus on the understanding of the concept of health.

\footnotetext{
${ }^{524}$ See supra note 46 and accompanying text.

525 Se supra note 52 and accompanying text.

526 The definition has been quoted in Chapter III, Part B, supra note 142 and accompanying text. Identical statements are to be found in the "Beijing Platform", supra note 80 in para. 94. Finally, the same recommendations have been repeated, and thus reaffirmed in the "Beijing Plus Five", supra note 84 in para. $107 \mathrm{~g}$ ter.

${ }^{527}$ GC 14, supra note 140. For the analysis of this Comment, see generally Chapter III, Part B (The right to heaith), above.
} 
The above evolution has also paralleled with the postulates made by some feminist scholars. As it has been noted by Ruth Dixon-Mueller "Concepts of health and illness are highly culture-bound." ${ }^{\text {"528 }}$ Observations like that have lead feminist scholars to question the narrow understanding of health - meaning treatment of disease and physical health - as ignoring, among others, the significance on the women's quality of life, their social well-being. mental and emotionai heaith of the safe and effective fertility control. 529

The need to respond to the health needs of women has lead to the development of the socalled "life-cycle approach" to women's health. This approach has been recommended. for instance. to the countries. State parties of the Women's Convention. in the General Recommendation 24 of the Committee on the Elimination of Discrimination against Women on "Women and Health." 530 The Recommendation puts emphasis on the fact that needs of women vary in different stages of their life, e.g. adolescence, reproductive years, maternity. older age. The right to non-discrimination of women in the field of health care. as guaranteed in Art.12 of the Women's Convention. ${ }^{531}$ requires from the states to report "on their understanding of how policies and measures on health care address the health rights of women from the perspective of women's needs and interests." $\$ 32$ In this respect, access to sterilisation can be particularly important for health needs of women in their older reproductive years, because they might not be able to use oral contraceptives. For this reason, health policy, which excludes sterilisation would not fully respond to the needs of older women. ${ }^{533}$

Returning again to the implied health harm of sterilisation, it is important to note that we are concerned in this work not with a harm, which is inflicted by anybody, but the "harm" inflicted by a health professional - a qualified physician, who performs the operation according

\footnotetext{
${ }^{528}$ Dixon-Mueller, supra note 78 at 147.

${ }^{529} \mathrm{Ibid}$. at 4 (ibid. at 140). Dixon-Mueller mentions talks about the possible manifestation of psychosocial stress, which could result, for instance, from the "fear of unwanted pregnancy or expectation of ill health from contraceptive use", such as: "depression, anxiety and hostility." (ibid. at 147) She also states, for example that "[I]t is probably safe to say that most women in most socio-economic circumstances are likely to experience extreme stress at some time in their lives that is triggered by sexual or reproductive events or conditions." (ibid. at 149). ${ }^{530}$ GR 24, supra note 146

531 "Women's Convention", supra note 137.

532 Ibid. para 12.

${ }^{533}$ See supra note 47 and accompanying text.
} 
to the medical standards of practice. Physicians in Poland have often expressed their appreciation for the health benefits of this method and a lot of them support its legalisation. ${ }^{534}$ It has been pointed out in Chapter two, that one of the harms of anti-sterilisation law is the questioning of the physicians' medical judgment of patient's needs and best interests or ethical judgment.

On the level of the individual decision of a physician to perform a specific procedure, he is assisted in his decision-making by guidelines given by the medical ethics. In favour of respecting the patient's judgement on what is beneficial for him, the principle of respect for the autonomy of a patient can be invoked. Beauchamp and Childress emphasise that this principle cannot be treated as overriding other moral considerations, and superior to the three other principles identified by these authors: principle of beneficence. non-maleficence and the principle of justice. ${ }^{35}$ In the case where a physician s judgement about what would be in the best interest of the patient overrides a patient's wish. we encounter the problem of paternalism. ${ }^{536}$ Beauchamp and Childress distinguish two forms of paternalism - weak and strong paternalism. The weak form of paternalism pertains to the cases where a person is protected from a potentially disadvantageous results of his decision, when this decision might not be fully voluntary, because of the inability to fully understand the consequences. ${ }^{537}$ The other form of paternalism - strong paternalism, "involves interventions intended to benefit a person despite the fact that the person's risky choices and actions are informed, voluntary, and autonomous." authors argue, the patient's decision should be respected, unless several conditions are satisfied:

1. A patient is at risk of a significant, preventable harm.

2. The paternalistic action will probably prevent harm.

3. The projected benefits to the patient of the paternalistic action outweigh its risks to the patient.

4. The least autonomy-restrictive alternative that will secure the benefits and reduce the risks is adopted. ${ }^{539}$

\footnotetext{
${ }^{534}$ Wprost, supra note 7 at 58.

${ }^{535}$ T. L. Beachamp \& J. F. Childress, Principles of Biomedical Ethics $2^{\text {nd }}$ ed. (New York: Oxford University Press, 1994) at 126 (Ibid. at 126. Ibid. at 181.).

${ }_{536} \mathrm{Ibid}$. at 271-290. The two authors quote the following definition of paternalism: "intentional nonaquiescence or intervention in another person's preferences, desires, or actions with the intention of either avoiding harm to or benefiting the person" at 274 .

${ }^{57} \mathrm{lbid}$. at 277.

538 Ibid.

${ }^{539} \mathrm{Ibid}$ at 283.
} 
The reason for invoking these deliberations in medical ethics is, first, to demonstrate that the protection of health interests of patients can be also made on the level of medical ethics, which are sufficiently equipped to safeguard the welfare of patients. Leaving the decision to the patient and individual doctor allows for taking into consideration the context of a life of an individual, circumstances of his case. Such circumstances cannot be sufficiently accounted for on the level of general policies.

Coming back once more to the implied health harm of sterilisation as a contraceptive method, we should note that the inability to procreate itself, at the particular moment in time. which results from the use of a contraceptive mean. has not been perceived as a health concern. or. at least it can be said that such a temporary state has not been considered as the state which requires intervention of law. Thus, it is only the permanent character and the irreversibility of this method, which distinguishes sterilisation and makes it a concern. The issue of irreversibility. and. thus. the protection from the post-sterilisation regret will be discussed below.

\section{Protection from Negative Implications of the Irreversibility of Sterilisation: Post- sterilisation Regret}

All throughout this work it has been stressed that sterilisation should be treated as a permanent method. However, one should note that the methods of reversal have been developed by surgeons. The success rates (rates of pregnancies following the reversal) for reversing vasectomy are usually given as ranging between 30 to $70 \%$ depending on the number of years passed between vasectomy and its reversal. ${ }^{540}$ The overall success rate of vasectomy has been often evaluated as $50 \%,{ }^{5+1}$ and the overall success of female sterilisation as $60 \%^{542}$ with the reservation that these rates depend on such factors as: a technique used for sterilisation, age of a

\footnotetext{
${ }^{s+0}$ See e.g. A. M. Belker et al. "Results of 1,469 microsurgical vasectomy reversals by the Vasovasostomy Study Group" (1991) 145(3) Journal of Urology 505, online <http:/www.vasectomy.com/Vasectomy-reversal.html> (date accessed: September 21, 2000).

$\$ 41$ G. S. Berger MD, Re: True \% of successful reversal, Reply to Michelle Killian on August 24, 1998, posted on the International Council on Infertility Webpage <http:/www/inciid.org/bb12/message 12/826.html $>$ (date accessed: July 12, 2000). See also Sterilization Reversal on AVSC International Webpage $<$ http://ww.avsc.org/contraception/csterrev.html> (data accessed: September 21, 2000).
} 
patient, health of a patient, the time which passed from the operation, and others. What that means is that this method is not totally irreversible, however, the reason for referring to it as permanent is that there is no guarantee of success and that access to reversal methods is limited, because reversal surgery is complicated and expensive and requires special expertise and equipment, which might not be available in some places. ${ }^{543}$ An alternative option to the reversal of sterilisation is In-Vitro Fertilisation. This option, however, is also very expensive. ${ }^{5+4}$

The majority of people undergoing sterilisation is very satisfied with this method. ${ }^{\text {5.5 }}$ However, a small minority, after the operation, regrets undergoing it. ${ }^{546}$ The regret and the wish to reverse the method, are often caused by changes in the life situation - remarriage - either after divorce or following the death of the spouse, or, sometimes - the death of a child. ${ }^{577}$ For some of those regretting sterilisation, as indicated above, the option of reversal will not be available or the attempt will result in a failure. The question is. whether it is necessary to abolish this method because of the fact that in some cases a person will regret the choice she has made and it will not be possible to reverse its consequences.

\footnotetext{
\$s2 AVSC International Webpage, ibid.

${ }^{43}$ AVSC brochure, supra note 44 at 6.

54 Nevertheless, some voices have been raised that. sterilisation should no longer be referred to as the permanent deprivation of the ability to procreate. See e.g. Wasek, supra note 10 at 95 . This suggestion has been also made by Rachael N. Pine, Esq., Director of Public Affairs, AVSC International in an interview on March 16, 2000. However, Pine also emphasised that this procedure should be referred to as the permanent method of contraception, and should not be used as a temporary measure. One could distinguish between talking about irreversibility of a method or permanency. We could refer to this method as permanent (since such is its intended result), but not irreversible. sss See supra note 51 and accompanying text.

$\$ 6$ The rates of post-sterilisation regret differ, depending on the source. Some of the numbers reported: A study in U.S - showed that $20.3 \%$ of women aged 30 years or younger at the time of sterilisation - regretted having at some point during the 14 years that have passed since sterilisation was performed, while only $5.9 \%$ of women over age 30 at the time of sterilisation reported any regret - S. D. Hillis et al. "Poststerilization Regret: Findings From the United States Collaborative Review of Sterilization" (1999) 93(6) Obstetrics \& Gynecology 889. The various rates of regret reported in different studies have been compiled in Philliber \& Philliber, supra note 67 at 14-15. They range from 0 to $45 \%$, however as authors indicated they were different understanding of the "regret" and different reasons for regret - not necessarily the fact of its irreversibility. One of the examples, the authors give is that in the study, in which the $8 \%$ of respondents reported regret, only $2.6 \%$ when asked whether they would do it again, said they would not. In another study, in Finland, also among women, the reported regret rate was $8.5 \%$ - E. Hemminki, A. Rasimus \& E. Forssas, "Sterilization in Finland: From Eugenics to Contraception" (1997) 45(12) Soc. Sci. Med. 1875 at 1880 .

${ }^{547}$ See e.g. AVSC brochure, supra note 44 at 3.
} 
The relevant factor in answering the above question is that there are particular groups of people undergoing sterilisation, who are more likely to regret their decision. The studies indicate:

Known risk factors of regret are: having young children; experiencing couple disharmony; being less than 30 years of age at the time of sterilisation; being sterilised during Caesarean section or shortly after delivery or therapeutic abortion. ${ }^{5.8}$

Other risk factors include: economic incentives used to encourage to undergo sterilisation. pressure or stress, or unresolved feelings about fertility. ":5:?

At least two solutions to diminish the risk of regret, other than completely abolishing this method, have been proposed in the specialist literature and in the practice of countries. One of them includes certain restrictions regarding the age and number of children that a person undergoing sterilisation has to have in order to be able to qualify for the procedure. ${ }^{550}$ The second solution is based on targeting these "risk" groups in counselling before the decision about sterilisation is made. Although these methods do not guarantee that the post-sterilisation regret will be totally eliminated, however. they limit its extent and also. should be considered as an alternative to more restrictive means.

\section{Protection from Abuse}

The opening quote of this part has revoked the fact that sterilisation has been sometimes utilised as means to some contemptible purpose. The examples of such abuses of this methods are given below.

\section{Examples of coercive sterilisation practices}

\section{(1) Nazi practices of coercive sterilisation}

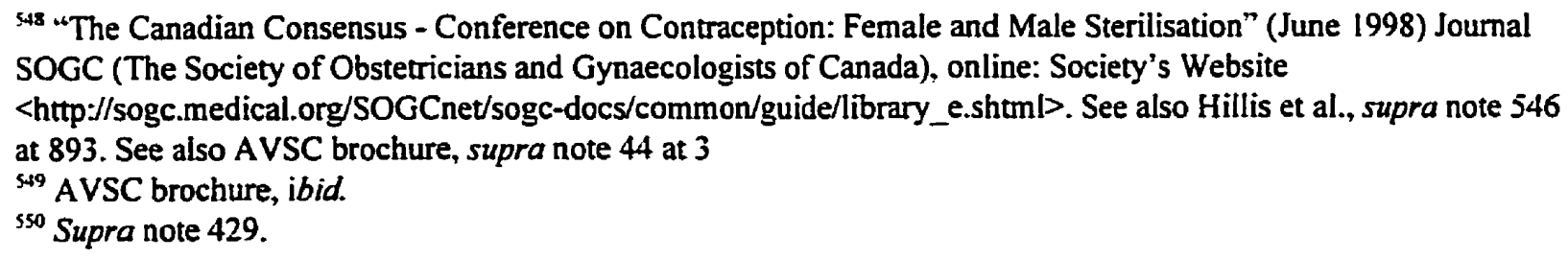


The most horrendous examples of these practices include sterilisation experiments performed on prisoners of concentration camps, in Birkenau, Auschvitz and Ravensbrück. ${ }^{551}$ These experiments, in addition to the fact that they have, in many cases, resulted directly in the death of those who were forced to undergo them, also have had a particular feature - their goal was to invent a method of mass sterilising of all those who would be deemed "unfit" by the Nazi ideology. This mcthod was intended to become a part of the Nazi genocidal plan to exterminate the "others." 552 One of the legislative proposals submitted during the war was a proposal to sterilise all Jews and half-Jews. ${ }^{593}$ These horrendous acts have been condemned as the crimes against humanity in the proceedings of the Nuremberg trial before the International Military Tribunal immediately after the end of the World War II. ${ }^{54}$

\section{(2) Eugenic sterilisation in Europe in the 1930s}

Compulsory sterilisation on eugenic grounds - aimed at 'improving' human race. by controlling fertility of 'unfit ${ }^{555}$ - mostly mentally incompetent - has been authorised in the 1930 s in many European countries: Sweden, Norway, Denmark, Austria. Germany, France. Britain. as well as in the United States. ${ }^{556}$ Formally, in most countries the law required the sterilisation to be voluntary. ${ }^{557}$ However, the consent to sterilisation has often been required for the release from mental institutions or as a condition for marriage. ${ }^{58}$

\footnotetext{
\$sI S. Trombley, The Right to Reproduce: A History of Coercive Sterilization. (London: Weidenfeld \& Nicolson. 1988) at 144-158.

\$s2 Ibid.

${ }^{553}$ Trial of the Major War Criminals Before the International Military Tribunal: Nuremberg $1+$ November $19+5-1$ October 1946 (Buffalo, NY: William S. Hein \& Co., Inc., 1995) vol. XX at 272 [hereinafter Trial of War Criminals].

${ }^{554}$ Ibid. See also, Trial of War Criminals, vol. I at 45-46 (Indictment). (See ibid. at 252 (Judgement)). These atrocities have inspired the text of the Genocide Convention - Convention on the Prevention and Punishment of the Crime of Genocide, 9 December 1948, 78 U.N.T.S. 277.

sss Trombley, supra note 551 at 2.

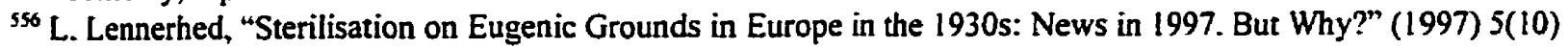
Reproductive Health Matters 156 at 156.

${ }_{557}$ See e.g. S. Hyatt, "A Shared History of Shame: Sweden's Four-Decade Policy of Forced Sterilization and the Eugenics Movement in the United States" (1998) 8:2 Ind. Int'l \& Comp. L. Rev. 475 at 485-486. See also Trombley, supra note 551 at 159 .

${ }^{558}$ Hyatt, ibid. at 486 .
} 


\section{(3) Coercive sterilisation in population control policies}

The last example pertains to coercive population policies which have been implemented in some developing countries in the 1960s and 1970s. The countries, which have been experiencing deep economic crisis due to overpopulation and lack of resources, such as India. ${ }^{559}$ $\mathrm{China}^{560}$ or Singapore, ${ }^{561}$ have introduced family planning policies to reduce fertility rates. Although officially the policies were based on voluntary measures, ${ }^{562}$ in practice the execution of the policies was, in many cases, coercive. The measures used to "persuade" population to use family planning methods, included in these, sterilisation. involved: economic incentives (money, gifts) or penalties for having big families (rendering housing, education. medical care. more difficult to access), as well as psychological pressure. threats and. in extreme cases. the use of force. $^{363}$

Lessons from the examples of coercive practices for the policy towards voluntary sterilisation

The first example has particular influence onto the Polish society, since most of the described atrocities have either taken place in Poland, or have involved Polish citizens. The memory of these horrors is still present in the society, in particular. in the older generations. Information about the second case have suddenly re-emerged and became a popular topic of media coverage in $1997 . .^{54}$ Similarly, information about the abuses of population control programmes have been reported in Polish media. ${ }^{565}$

\footnotetext{
559 See e.g. Boland, "Honoring Human Rights in Population Policies: From Declaration to Action" in Population Policies Reconsidered, supra note 102, 90 at 97-98.

${ }_{560}$ See e.g. Issacs, supra note 412 at 363 .

561 lbid.

${ }^{562}$ See e.g. statements of Chinese government officials cited in Boland, supra note 559 at 98.

${ }^{563}$ See e.g. ibid. at 98.

${ }^{56 t}$ See e.g. Lennerhed, supra note 556. In Polish media - see e.g. N. Gurfinkel, "Skandynawia: Gdzie sa dzieci z tamtych lat" (Scandinavia: Where are the children of these years) Rzeczpospolita (19 September 1997).

${ }^{565}$ See supra notes $115-117$ and accompanying text.
} 
All of these factors have a result in that the word "sterilisation" itself might have a negative associations in the popular mind, and that, this method might be seen as a measure, which is inherently susceptible to abuse by various forces.

However, it is very important to emphasise again, that this method is being also used by many people, fully voluntary, all over the world, and those who use it voluntary are finding this method as highly satisfactory, as a positive experience.

The wrong, which has taken place in the given above examples is not in the method itself. This method is perceived by some as beneficial. and by some. as it has been discussed in earlier sections, as immoral or detrimental to health. Moreover, it might be beneficial for a person in the given life-situation. and might have not been beneficial for the very same person, when her personal and life situation has been different. The harm of the given examples was in the goal that sterilisation was designed to assist in achieving. The goals were not set by those who had to undergo this procedure but by their oppressors or authorities without the respect for their welfare. In addition to that, it was the coercion which has been the harm. the fact that the individuals were not able to refuse undergoing the sterilisation, but were forced - either by economic or psychological pressure or the use of force.

In conclusion, this method, itself, is not bad or good from the point of view of its inherent susceptibility to abuse, however, the issue of the possibility that a person undergoing sterilisation is not doing it because he wants to do it, but because he submits to some external pressure, is still to be resolved. There are two important points to be made in this place with respect to the existence of the external pressure to undergo sterilisation.

First, such potential of abuse, coerced nature, exists practically in the case of any medical procedure. It can also exist in the case of other contraceptive methods. However, the potential of abuse in the case of sterilisation has been emphasised in the literature because of the difficulties with reversing this procedure and redressing its consequences.

Second, if we take the most classical example of sterilisation acceptors: a married couple with three or even more children, more often than not, their decision to not have more children and their preference to employ sterilisation to achieve this goal, is a result of the combination of the insufficiency of two resources: time or money. Thus, it has to be accepted that in the majority 
of cases, some degree of economic or social conditioning will always be present in the case of sterilisation. But this, again, would also be true in the case of other contraceptive means. Some economic or social conditioning are usually present in most life decisions. It seems that only when they exceed certain accepted level, there is the need to be seriously concerned about it and to eliminate them, so that. they would not amount to the practical discrimination on the ground of poverty or social situation, including gender.

The situation which are of the concern, thus. are the situations were sterilisation is chosen only because it is the cheapest method and the family cannot afford other methods. In this situation it would be discriminatory for the poor people, who. if they had other methods accessible to them. would have chosen methods. which they would view as more beneficial for them.

And, the second situation, takes place. for instance, when one partner in the relationship. more often a woman than a man, submits to pressure from another partner, even though she would prefer a different method of contraception.

The overview of various studies concerning sterilisation. conducted by the Phillibers, has found that there is no clear link between socio-economic status and the prevalence of sterilisation. ${ }^{566}$ However, some studies demonstrate that women, who undergo sterilisation, are more often less educated, coming from "lower social classes" as compared to women using other methods of contraception. ${ }^{567}$ Again. not the fact that this method is being used by such groups of society is a concern. The concern arises when this method is chosen because other methods, which would otherwise be chosen, are unaffordable or inaccessible.

Similarly, the higher prevalence of female sterilisation and the fact that women sometimes report that they were sterilised because their partners refused to undergo vasectomy, ${ }^{568}$ can prompt concerns whether the women's choices are always fully voluntary.

There have been certain policies proposed in the contemporary literature which are to address, among others, the above described concerns First, the final decision about sterilisation

\footnotetext{
506 Philliber \& Philliber, supra note 67 at 2.

${ }^{567}$ Hemminki et al., supra note 546 at 1879.

${ }^{568}$ Philliber \& Philliber, supra note 67 at 7.
} 
should be preceded by the particularly safe-guarded decision making process (the requirement of the free and informed choice) ${ }^{569}$ Laws of some countries require specialist counselling to be part of this process, ${ }^{570}$ doctors are obliged to provide with information about the alternative contraceptive methods, the nature of the operation, its risks, irreversibility, and other features of the method, ${ }^{571}$ a waiting period might be obligatory between the decision and the operation, when the person can change her mind, ${ }^{572}$ the spousal consultations might be encouraged.

Medical ethics informs our understanding of the free and informed consent. Many medical associations - national and international - have developed excellent guidelines concerning generally the institution of the free and informed consent or specifically ethical issues with regard to sterilisation and difficulties it may pose. For instance. the International Federation of Gynecology and Obstetrics (FIGO) published guidelines entitled "Ethical considerations in sterilization", which read:

6. Special informed consent considerations inherent in sterili[s]ation counselling include:

(a) Sterili[s]ation is intended to be permanent:

(b) Life circumstances may change:

(c) The patient may later regret her sterility:

(d) Male sterili[s]ation may be an appropriate alternative:

(e) There is a measurable failure rate with any sterili[s]ation procedure. ${ }^{573}$

The guidelines stress the importance of paying special attention to detecting possible pressures on a person considering sterilisation, for instance, by emphasising the discussed earlier fact that "Women may be vulnerable to various forms of coercion in their medical decision making." "574 The guidelines also usually encourage the involvement of a spouse or partner in the counselling process, because "[i]n many cases, it is preferable for the male partner to be

\footnotetext{
${ }^{569}$ See e.g. $x x$ ?

570 Such is the case of Romania - the issue is regulated by medical guidelines - see "Women's Reproductive Rights in Romania: A Shadow Report" (CRLP, Romanian Society for Feminist Analysis AnA, 2000) at 16.

571 Such requirements are provided in the Hungarian legislation concerning access to sterilisation, supra note 429.

${ }^{57}$ In Hungary - normally, at leas a 3-month waiting period is required - ibid.

${ }^{573}$ International Federation of Gynecology and Obstetrics (FIGO), Recommendaions on Ethical Issues in Obstetrics and Gynecology by the FIGO Committee for the Study of Ethical Aspects of Human Reproduction (London: FIGO, 1994) at 13.

${ }^{574}$ The American College of Obstetricians and Gynecologists (ACOG) "Sterilization of women, including those with mental disabilites" (1999) 65 Int'l J. Gynecology \& Obstetrics 317 at 318 . These guidelines were formulated by the ACOG's Committee on Ethics, replacing earlier guidelines published in 1989.
} 
sterili[s]ed. [Thus it] may be helpful for the physician to counsel the partner directly ...."575 Such involvement would give an opportunity to discuss the alternative contraceptive options for the partner, as well as, to learn about the stability of the relationship. It is also emphasised in the guidelines that physicians are not left alone in their decisions concerning patients who wish to undergo sterilisation, but "are encouraged to seek legal or ethical consultation ... whenever nccessary in their cfforts to provide care that is most appropriate in the individual situations."576 With such safe-guards, the decision-making process could significantly limit the probability of the abuse and coercion in the use of this method. It is also important to emphasise that the view that only the criminal proscription could protect individuals from coercion or regret. stigmatises Polish doctors by implying that they cannot themselves come up with a system of free and informed choice. This is truly controversial in the view of the excellent guidelines developed in the practice of other national and international medical associations.

Another safeguard of the voluntary choice is the accessibility and affordability of the full range of other contraceptive methods. ${ }^{577}$ It is the lack of other affordable methods which could contribute to the situation where sterilisation is not chosen because of its overall positive evaluation by an individual, but because of his not being able to afford any other method.

In the response to the concern over the possibility of women being pressured by their partners to undergo sterilisation, the following issue has been raised. It has been pointed out that such situation might signal a bigger problem of women's lower status and their lack of power in family and in the society. This is also linked to the society's or husband's expectation that a woman should be responsible for the family planning and its burdens and consequences. ${ }^{578}$ Such a problem needs to be resolved by the policy aimed at the improvement of the status of women and by socialising men into a responsible sexual and family roles. This issue has been partly addressed in the chapter concerning harm of the denial of sterilisation.

\footnotetext{
575 Ibid.

576 Ibid.

577 AVSC International, "Balancing Protection and Access: Assessing Sterilization Policy" (fact-sheet, brochure) (New York: AVSC International, 1999) at 5.

s78 lbid at 6.
} 
Finally, one more remark will be made in this place with reference to the present situation in Poland. At present, when sterilisation is illegal, while at the same time it is being performed sporadically, there is no control over the way the decision-making process is being made in these illegal cases. The specific regulation and guidelines, targeted at the prevention of regret and the prevention of involuntariness, which should be provided were this method to be legalised in Poland, would give more guarantee that an abuse would not take place than the present situation. 


\section{PART E. Conclusion}

The purpose of this chapter was to juxtapose two streams of arguments. On the one hand, we have the argument, which has been made in the Chapter III - that harmful and negative implications of anti-sterilisation law would allow to claim that this law violates human rights provision - the right to respect for private and family life and the right to gender equality. On the other hand, we have arguments against legalisation and popularisation of contraceptive sterilisation, which can be based on concerns associated with negative features of this method. Such concerns were briefly outlined in chapter two, part c. Each part of this chapter started with explicating, how, on the basis of these concerns, the argument against legalising sterilisation could be substantiated. Furthermore, such argument was analysed to detect its potential weaknesses.

In Part B I discussed first of the potential grounds for the justification of the retention of anti-sterilisation law - the argument based on the demographic concern. Such concern is associated with the permanent character of sterilisation - the fact that sterilisation. in principle. puts an end to the procreative capacity of a person. It is also associated with the demographic situation of Poland, in which a recently observed trend - falling of birth rates below the replacement level and the ageing of the population - have invoked reasonable concerns over its impact on: pension, housing, education, health care and social services systems. The question put forward in this part thus, was whether the concern that the use of contraceptive sterilisation might have some impact on population trend, could justify anti-sterilisation law. Many factors, which need to be taken into account before an adequate answer can be given to this question, were named in this part. First, it has been pointed out that it is necessary to consider the extent of the potential impact of the use of sterilisation on birth rates, which, according to specialist literature might be quite limited in practice. Second, the attention was drawn to the following fact. In order to purse the argument that proscription of sterilisation constitutes a necessary element of a pronatalist population policy, a comparison between this and other measures which could be employed in its place must be made. This comparison needs to be based on several criteria, most importantly, effectiveness and restrictiveness of the measure. 
In verifying the effectiveness of this method, the first step, which needs to be taken, is the precise identification of the nature of detriment, which can result from the observed demographic changes. This step is necessary for the evaluation whether proscription of sterilisation is of use for addressing the harm. In this analysis of detriment, non-demographic factors need to be taken into account, such as the recent reforms in Poland of pension system and health-care system and thcir potcntial to prevent the anticipated harms. A factor which has a bearing on the effectiveness analysis is the fact that delegalisation of a method does not completely eliminate its use, but results in driving it underground or affecting disproportionately a particular group of the society.

Furthermore. it has to be taken into account that proscription of sterilisation is a much more restrictive measure than a lot of other measures proposed in the specialist literature to address demographic concerns. Such measures have been classified into three different categories: measures to increase fertility by incentives. measures to increase immigration and the decision to adapt to demographic change rather than attempt to influence it. Sterilisation is particularly controversial because of imposing special burden on the lives of women. Less restrictive measures, such as economic incentives directed to responding to people's own needs, should have been proven ineffective. before the ban on sterilisation could be justified. To this end, this measure should be considered as not proportionate to the population goal. Another less restrictive measure employed in other countries, which should be given priority before the total criminal ban on sterilisation could be pursued is the potential limitation on access to this method based on age limits or the number of children a person must have. This measure is also controversial, but less restrictive than the total ban. Furthermore, the ban on sterilisation. has not been considered as necessary in other democratic countries, for the purpose of population policies, despite of their experiencing similar demographic changes.

In conclusion, the pronatalist atmosphere in Poland, which is manifested in the Profamily Policy and other social policies of the present government, would support the resistance to the legal reform regarding sterilisation and lead to invoking claims that anti-sterilisation law is necessary to protect the national interest of Poland in reversing "negative" population trends. However, this measure cannot be justified as such because of the existence of less restrictive measures which could be also more effective in addressing the state's concerns. 
In Part C I explored the legitimacy of the potential justification that anti-sterilisation is necessary for the protection of public morality in Poland. Using the language of the European Convention, I have inquired whether it is possible to claim that the retention of the criminal proscription is necessary for the protection of morals and thus, a justified interference with the right respect for private and family life or the right to equality. If it was possible to justify this measure solely on this ground, it would be recommended to clarify that the measure is criminalised on the basis of its threat to morality and not as a threat to the health of a person. and. for this reason, to classify it as an offence against morals. The approach of the European Commission and Court is such that the state which invokes the protection of morals as justification of certain policy, should be permitted a wide margin of appreciation in arguing its necessity to achieve this goal. However. it was argued here that in the case of anti-sterilisation law, or any regulation which pertains to the sphere of reproductive health and rights, because of the unique character of this sphere and its particular interrelation with the situation and lives of women, deference to national authorities could have a disproportionate and harmful effect on women. Such situation results from the insufficient representation and influence of women's on national authorities and in the public debate.

Concerns that the use of sterilisation for contraceptive purposes might conflict with a value system of the Polish society: because of the influence of the Roman Catholic Church teaching; or secular value system ascribing special values to family, ability to procreate, maternity, does not justify the retention of anti-sterilisation law for several reasons.

First, closer scrutiny of such concerns reveals that there seems to be no widespread consensus over the condemnation of sterilisation as a contraceptive method in the Polish society. Moreover, it can be argued that making sterilisation accessible is not necessarily inconsistent with family values, for instance. Also, the absolute condemnation of this method by the Roman Catholic church, along with other modern contraceptive methods, meets with criticism that it is inconsistent or inadequate to contemporary times. Another reason is the society's perception of the limited role the church's teaching should play in the political or legislative process of a democratic and pluralistic state. Furthermore, according to available data on public opinion on this issue, there seems to be more support in favour of liberalising sterilisation than in holding it 
necessary for the protection of moral norms. The lack of enforcement of the law or demand for its enforcement also support hypothesis that there is no "pressing social need" for the proscription. Likewise, the fact that this method has been legalised in the prevailing majority of European countries demonstrates the evolving consensus as to how this issue should be addressed in a democratic and pluralistic society. Finally, the criminal ban on sterilisation might not be the most cffective and the least restrictive measure to achieve goals which are said to be advanced through this law.

Finally, part $\mathrm{D}$ was devoted to micro-concerns, concerns over the irreversibility, the risk of regret, or abuse of this method, as well as the general concern over the implied harmful effects of this method on the well-being of individuals who might choose this method if it was easily accessible. The three categories of concerns discussed in this part are very important and need to be addressed appropriately. Ignoring them could be very harmful. However. the question put forward was whether the best response to these concerns is to make this method illegal and inaccessible for individuals.

First. it can be concluded from the juxtaposition of health benefits and health risks of this method that it should not be viewed as inherently bad or good - it might be very beneficial for certain groups of society - for example women in their later reproductive years, or for those who might not be able to use other methods of contraception, while, at the same time it might be not recommended in other circumstances. What can be ascertained is that many physicians included in this Polish physicians - appreciate greatly benefits provided by this method to their patients. This supports the positive opinion held by the prevailing majority of those using this method voluntarily in other countries of the world. On the other hand, protection of health interests of those for whom this method might not be recommended can be made on the level of the patient-doctor relationship with assistance of medical ethics and guidelines developed by medical associations.

Furthermore, with regard to the potential of regret, it has been ascertained that not only the rate of regret is not very high, but also that it is possible to identify certain "risk groups" and "risk factors", which contribute to the higher probability of regret. As a result there exists a less 
restrictive option - the targeting of such groups and factors in the counselling process prior to the operation.

Finally, with regard to the problem of involuntary sterilisation practices, two issues have been pointed out. First, that we should not talk about sterilisation as inherently susceptible to abuse, despite of historical examples. However, because of irreversibility, special attention should be hecded to guarantee a fully free choice of this method. To address the issue of safeguarding voluntary choice of sterilisation, in general, other, less restrictive then the criminal proscription, means, were discussed in this work: the system of free and informed consent informed by medical ethics and a more restrictive, although not as restrictive as the total ban. measure - the introduction of requirements as to the age and number of children that a person. who wishes to undergo sterilisation must have. We should note that the last option - the restrictions on access to the method meets with certain controversies. ${ }^{579}$ although it is still a popular solution adopted in several European countries. ${ }^{580}$ The Human Rights Committee in its General Comment on equality of rights between men and women indicated that:

States may fail to respect women's privacy ... where general requirements are imposed for the sterilisation of women. such as having a certain number of children or being at a certain age... ${ }^{\text {s1 }}$

However, it is not clear, whether the evaluation that such restrictions could amount to a violation of human rights applies only with regard to cases where women are treated differently than men, or generally to restrictions of access, which are applied equally to both genders. In general, it can be said that any restriction on access to contraceptive means is controversial and potentially infringing on the rights of individuals and that it might not accommodate difference, special needs and particular circumstances of the case. However, such restrictions as age limits are still less confining than a total ban on sterilisation, and thus, less infringing on individual rights. Ideally, limits should be introduced not as legal limits, but as recommendations for providers (guidelines for providers). They could also be introduced initially in law, but leaving an option of progressively moving them to guidelines, or, perhaps, gradually lowering the legal

\footnotetext{
579 See supra note 428 and accompanying text.

${ }^{580}$ For examples see supra note 429.

${ }^{581}$ GC 28, supra note 153, para. 20.
} 
limits. This view is inspired by the notion that stringent legal restrictions will not be sufficiently flexible to accommodate particular situations and different needs. Furthermore, this approach allows to adjust the restrictions (or guidelines) to patterns that are discovered in practice of providing this service, to verify their necessity, and, possibly amend them after an initial period following the legalising of contraceptive sterilisation. Such regulation, as it has been noted, could be more protective of the welfare of patients uhan the present situation in Poland, when there is no regulation and guidelines concerning the decision-making process at all.

The reason why these less restrictive options should be chosen to prevent individuals from the implied harms of contraceptive sterilisation. is the extent to which the lack of this method is harmful for the society. It has been emphasised in this section. not for the first time. that this method, in the expert opinion, is still evaluated as one of the safest contraceptive method. Furthermore, the fact that a small minority will end up regretting undergoing this procedure. cannot outweigh the fact that the prevailing majority finds this method highly satisfactory and beneficial for them. Its benefits influence positively sexual life and the overall well-being of individuals and couples. These benefits, according to the international consensus. as demonstrated in such documents as: the Beijing Platform and the Cairo Programme, influence the sexual health of individuals, and should be treated, according to these documents, as indispensable elements of health. Many national and international medical associations have developed excellent guidelines on counselling persons interested in undergoing sterilisation to ensure that they make a free and informed choice about this procedure. Medical ethics inform our understanding of free and informed consent. To claim that the only effective way to protect health interests of patients is through the criminal proscription of this method is to imply that Polish physicians could not protect the welfare of their patients through the system of informed and free consent, developed by them. This is highly controversial in the view of excellent guidelines developed by other national medical associations. 


\section{CHAPTER V.}

\section{CONCLUSION}

Polish anti-sterilisation law has its source in Article $156 \S 1$ of the Criminal Code. ${ }^{582}$ Although some controversy exists in the Polish legal doctrine as to the sphere of application of this article; the plain meaning of it, the characterisation of contraceptive sterilisation in media and popular publications or other available sources of information, as well as, some official government statements; all reaffirm the restrictive interpretation of this article. This shapes the legal awareness about this procedure in the society and has a deterrent effect on medical profession. Doctors have too much at stake to risk performing illegal sterilisation. They could potentially face criminal prosecution. despite the fact that the law. so far, has not been enforced in practice. There is also a potential risk of a loss of a professional licence or credibility. Thus. contraceptive, non-therapeutic sterilisation is practically unavailable or. at least. very difficult to access in Poland. The exact number of illegally performed procedures is not known. The available data is anecdotal. However, it allows to infer that the number is very low. Female sterilisation is more popular than vasectomies. One factor contributing to this situation is the lack of publicly available information about benefits and possibility of undergoing this procedure. In particular, such shortage pertains to information on male sterilisation.

Sterilisation as a contraceptive method has a lot of positive features: it is highly effective; there is no user-failure; it is convenient - easy to use, because it requires only few visits to a specialist and no regular follow-up visits or applications. This method can be described as very private, giving an option of confidentiality. It is also cost-effective and safe - has a minimum amount of side-effects. For men, it is one of two practically available to them, methods. Furthermore, more than ninety percent of users of this method are satisfied with it, especially because it positively influences their sexual life and health. Certainly, sterilisation is not an ideal method. Its shortcomings are such that it requires surgical intervention and thus, might carry

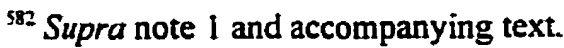


risks associated with it. Also, it may not be reversible. Moreover, it does not provide with protection from sexually transmitted diseases. Sterilisation may result in heavier bleeding or menstrual pain. Finally, there is a certain risk of ectopic pregnancy in the case of female sterilisation, following contraceptive failure or reversal. Despite these shortcomings, sterilisation is considered as one of the safest contraceptive methods. Its positive features make it one of the most popular methods in the world. Access to this method might be particularly beneficial for either of the partners of a married couple (or otherwise permanent relationship) with children. because they are in a position to decide that irreversibility of this method is no longer a barrier. The lack of access to sterilisation needs to be viewed from the point of limiting available contraceptive option. The importance of a comprehensive range of contraceptive options flows from the fact that contraceptive needs vary according to health conditions. stage of life, age. family situation and many other factors.

The inaccessibility of contraceptive sterilisation in Poland has or, can potentially have. multiple negative implications. The general impact is that individuals might either not be able to find a suitable method or apply a method which does not give them as much security and comfort as sterilisation could, and thus, they might not be able to fully satisfy their need for sexual intimacy. This circumstance can result in impaired sexual well-being, and also lower self-esteem. In addition, different groups of society can experience the lack of this contraceptive option differently or to a varying degree. For women, there are further implications of their inability to control fertility, such as their limited educational or professional development opportunities. Another important factor is that sexual intimacy and sexual well-being of partners is important for the enhancement of the relationship and that deficiencies in this sphere might potentially lead to relational problems, turning to other partners, and thus, weakening of the existing bond. Furthermore, the inability to control a size of a family can have impact on parents' ability to fulfil their parenting roles and result in their not having enough time and resources for giving sufficient attention to social, emotional and intellectual development of children, as well as, for couple-oriented activities. Moreover, criminal stigmatisation of sterilisation can result in imposing one moral stance without due respect for different views. Also, by giving excessive emphasis on the maintaining of the ability to procreate, the criminal proscription has a potential 
to turn this ability into a burden rather than a value. Furthermore, the inaccessibility of this highly effective and permanent contraceptive method stands in the way of a fuller and faster shift from "abortion culture" to "contraceptive culture." prohibition has also harmful implications for doctors. Its existence interferes with their professional freedom and their judgement of what is in the best interest of their patients.

The iclation between access to sterilisation and sexual or reproductive health has prompted the question of its protection by the human rights provision of the right to health. We can talk, in this respect, about the increased support and the evolving consensus on the wide conception of health. This understanding of the term "health" is reaffirmed in such international documents as the General Comment 14 of the Committee on Economic. Social and Cultural Rights. ${ }^{584}$ the Cairo Programme of Action ${ }^{555}$ and the Beijing Platform of Action. ${ }^{586}$ This wide conception encompasses mental and social well-being, reproductive health and. most importantly, sexual health, "the purpose of which is the enhancement of life and personal relations, and not merely counselling and care related to reproduction and sexually transmitted diseases. ${ }^{" 587}$ However, legal enforcement of harms pertaining to non-physical elements of health does not yet find sufficient support in the human rights provisions and jurisprudence of international bodies such as the Economic Committee. These aspects are certainly subject to political accountability of state. Furthermore, as Aart Hendriks suggested, a more effective strategy and a stronger argument can be made by demanding implementation of these elements through the enforcement of related classical rights. I have thus, argued further in my work that challenge to anti-sterilisation law can be made through the invocation of the right to respect for private and family life and the right to equality.

Existing jurisprudence of European Commission and Court of Human Rights and the Human Rights Committee give sufficient support for making an argument that the Polish anti-

\footnotetext{
${ }^{583}$ M. Horga \& F. Ladicke, "How Can Rates of Induced Abortion Be Reduced?" in Towards Better Reproductive Health in EE, supra note 90,99 at 99.

${ }^{54+}$ Supra note 140 and accompanying text.

${ }^{585}$ Supra note 105.

${ }^{586}$ Supra note 80.

${ }^{587}$ Supra note 142 and accompanying text.
} 
sterilisation law violates the right to respect for private life. I have argued that a decision about sterilisation is a fundamental personal choice and that it belongs to the sphere protected by this right. Lack of access to this method can have a bearing on one's sexual expression and wellbeing and the ability to arrange one's sexual sphere. It can lead to the interference with sexual intimacy and the ability to control a size of a family and to other harms invoked above. The state could justify this law only by demonstrating that the interference is necessary in a democratic society for the protection of important public interests, such as: protection of the economic wellbeing of the country, protection of health, protection of morals or protection of the rights and freedoms of others. The concerns associated with legalising contraceptive sterilisation are following: its potential impact on exacerbating demographic crisis and thus. potential negative impact on the capability of dealing with such spheres of public services as pension. housing. education, health care and social services systems. Another concern is the implied coming into conflict with moral norms of the society or undermining values important for the preservation of the national identity. Finally. I have analysed the implied harmful character of this method. most importantly its irreversibility, risk of regret or abuse. Such concerns justify taking special measures with regard to regulating access or formulating guidelines for the provision of this service. However, they cannot justify such degree of interference with the right to respect for private life as the criminal proscription of sterilisation.

The rejection of such justification of anti-sterilisation law is based on the application of principles developed in the jurisprudence of the European Commission and Court of Human Rights. First, the criminal ban on sterilisation is a very restrictive measure. There are at least several possible alternatives, which would result in a lesser harm to individuals and could still protect public interests. These include: economic incentives or the adaptation to demographic changes rather than attempt to change. Another option is the more controversial imposition of certain limits on access to this service according to age or number of children. Furthermore, most recommended of such alternative - the system of counselling, free and informed consent - guided by medical ethics - can protect the well-being of potential patients. Second argument against the necessity of the criminal proscription of sterilisation is that there seems to be no widespread consensus in the Polish society on the point that this measure is necessary. This can be inferred 
from the available data on public opinion supportive of legalisation of this method or from the lack of demand for the enforcement of existing law. Furthermore, regulation of sterilisation in domestic laws of he majority of European countries and many non-European countries demonstrates the emergence of the European and world consensus as to how this issue should be resolved in a democratic and pluralistic society. Likewise, we can talk about expert consensus, in particular, the support for the accessibility of this method by medical profession. including Polish doctors. Many representatives of the medical profession view this method as having the potential for positively influencing sexual life and health and the overall well-being of their patients. For all these reasons, the discussed grounds for justification of the Polish anti-sterilisation law cannot stand.

I have also explored whether the right to have access to contraceptive sterilisation can be given protection by the right to respect for family life. The existing case law on family life does not give sufficient support, at this point, to make such claim the strongest and most effective argument. This can be inferred from the fact that, so far, violation of this right was held in cases where there was interference of the most drastic nature - such that would eliminate the ability to live together, to establish family ties or to meet regularly. Nevertheless. the category of interference with family life imposed by anti-sterilisation law - interference with a substance of such life, with conditions in which children's development takes place - could potentially be hels as a violation, especially, if there was more and stronger evidence to demonstrate that the harms are not speculative but actual. Regardless of the effectiveness of such argument, it is important to emphasise the harm to family life of anti-sterilisation law so as to avoid accusations that the law is being challenged solely on basis of individualistic interests.

It is also feasible to argue that anti-sterilisation law; in addition to violating the right to respect for private (and potentially family) life; constitutes a violation of the right to equality. This due to the fact that this law has a disproportionate, adverse and discriminatory impact on women. Such argument is very challenging because it requires to reconceptualise what kind of the impact of law can be viewed as discriminatory. In this case, anti-sterilisation law applies equally to both genders. It does not make a distinction between women and men. However, this law singles out a service, the accessibility of which, could have a particularly beneficial impact 
on the quality of women's lives and on alleviating their disadvantaged position. The law, as it stands now, does not create disadvantage, but it maintains or even exacerbates such disadvantage, the disadvantage, which results from biological differences or stereotypical roles imposed by the society and which limits women's opportunities for educational, professional or social development.

All in all, the anti-stcrilisation law can be challenged as violating both the right to respect for private (and potentially family) life and the right to equality, and cannot be justified by invoking concerns discussed in this work. Thus, rational claims supported by the international human rights provisions, can be raised to demand from the Polish authorities to introduce appropriate legislative changes to address the implied violation by legalising access to this contraceptive method.

At the time of drafting of the human rights treaties invoked in this work: the European Convention on Human Rights and the International Covenant on Civil and Political Rights. domestic laws of the majority of State Parties did not permit contraceptive sterilisation. For this reason, one could argue that the States Parties could not have intended or contemplated that the right of access to this procedure be embraced and guaranteed by the right to respect for private life or the right to equality. However, human rights treaties are living instruments, they are given a progressive and dynamic interpretation. When these two human rights treaties were drafted. the question about the protection of reproductive health and rights was not asked or, at least, not understood fully and not considered with sufficient regard to its implications. The growing prominence of women's voices in public debate, including on the international arena, the emphasis given by international bodies to issues of equality and viewing women's rights as human rights, as well as the emergence of the reproductive health movement; resulted in asking such question repeatedly and expecting a considerate and unbiased answer. This answer requires at present a better understanding of the actual nature of harms resulting from laws and policies restricting access to guarantees of the full enjoyment of reproductive rights and health.

I have tried to demonstrate in this work that it is important to step back from values, abstract principles and entrenched concepts, often stereotypical, such as womanhood, motherhood, pregnancy, reproductive choice; or from the debate over what is more important - 
the right to reproduce or the right to not reproduce. Our understanding of such concepts or values "so often survive[s] chiefly by their stamp of unchallengeablility" as Jed Rubenfeld stated. ${ }^{588}$ When we take a challenge of reconceiving these concepts, we can find basis to critique antisterilisation law from the reproductive rights perspective. Among the fundamental principles or methodology that I have attempted to apply in this work is the taking of a very close and unbiased look at the realitics of reproductive choice, at what it really means for a family to be able to make this choice, to have or not to have resources to do so, the reality of dealing with unwanted pregnancy, enforced parenting or unmet need for sexual intimacy. I believe that from the reproductive rights perspective, special emphasis needs to be given to a women s perspective and women's understanding of the realities of contraception. because of their still particular position with regard to reproduction and because of the social-justice approach - the fact that women's views on these issues have often not been taken into account in formulating laws and policies which affect the sphere of reproductive health. There are solid legal grounds for contesting anti-sterilisation policies as contravening equality rights. However. without genderdriven understanding of contraception and contraceptive policy, the argument made in this work might have less force and be less persuasive. Once again, the approach applied in this work was based on: contextualising reproductive choice, reality of it. identifying the precise nature of harm, giving special emphasis to gender perspective, as well as challenging stereotypical concepts, entrenched values and abstracted principles and giving due respect to human rights. This framework could be applied to analyse other laws and policies in the sphere of reproductive rights and health. I have attempted to offer theoretical and some empirical grounds for support of my proposition - the legal challenge of anti-sterilisation law. However, this debate may have implications beyond the particular sterilisation debate. Anti-sterilisation law does not work in a vacuum. There is, most importantly, the need to develop a comprehensive strategy for reproductive rights and health. If nothing else, these kinds of debates should invigorate and inspire the discussion over principles on which such strategy should be based. The principles which have been discussed in this work are, among others: the respect for human rights, and, in

${ }^{588}$ Supra note 259 and accompanying text. 
particular, privacy and equality rights, which are supportive of a free reproductive choice; the need for a gender perspective; the need for a precise formulation of the nature of harm which could be imposed by particular policies, bearing in mind that such harms can be identified only by looking closely at the realities of lives of individuals and taking into account particular circumstances of lives of various groups in a society; accommodating differences; and, finally, challenging and reconcciving stercotypes, entrenched beliefs. rejecting or, at least, taking with precaution and suspicion debates over abstracted principles isolated from people's realities.

I should note some of the limitations of this work. First of all, I focused only on a legal reform. solely on the question of legalisation of sterilisation. This. in fact, would only be a first step in making this method practically available for everybody. This thesis did not attempt to address another crucial issue - the question of public funding of this procedure and its coverage by health insurance, although some of debates in this work should be also helpful for resolving this issue. Furthermore. I limited my discussion to finding arguments to challenge the criminal provision applying to sterilisation. I did not, for example, go more in-depth into discussing the most efficient advocacy or litigation strategy to actually bring the proposed change. The instruments and mechanisms that should be explored in this context include: on the domestic forum: legislative initiative. constitutional complaint or complaint to Human Rights Ombudsman; and on the international: complaint to the European Court of Human Rights or the Human Rights Committee and finally, the new, not yet in force, complaint procedure under the Convention on All Forms of Discrimination Against Women. Moreover, I did not discuss in detail the way access to this method, if decriminalised, should be regulated. Legalisation of this method would require to formulate special guidelines for its provision, dealing with such issues as: who would be qualified to perform the procedure, restrictions, if any, on access to the method or the guidelines safeguarding free and informed choice of sterilisation acceptors. A brief discussion of such regulation in the Polish legal literature has been made Eleonora Zielinska. ${ }^{589}$ The development of such guidelines should be based on comparative analysis, taking into account best practices from other countries.

\footnotetext{
589 "Conditions of Admissibility", supra note 4.
} 